\title{
Transitional Jurisprudence:
}

\section{The Role of Law in Political Transformation}

\author{
Ruti Teitel ${ }^{\dagger}$
}

\section{CONTENTS}

I. The Rule of Law in Transition . . . . . . . . . . . . . . . 2016

A. The Rule-of-Law Dilemma: The Postwar Transition . . . . . 2018

B. Shifting Visions of Legality: Post-Communist Transitions . . 2022

C. Transitional Constructions of Legality . . . . . . . . . . . 2026

1. The Role of Social Construction . . . . . . . . . . . . 2026

2. The Role of International Law . . . . . . . . . . . . 2028

3. The Rule of Law as Antipolitics . . . . . . . . . . . . . 2029

D. The Transitional Judiciary . . . . . . . . . . . . . . 2030

E. The Transformative Adjudicative Domain . . . . . . . . . 2034

II. CRIMinal Justice . . . . . . . . . . . . . . . . . . . . . . . 2036

A. The Dilemma of State Crimes but Individual Justice . . . . . 2038

B. The Nuremberg Paradigm Shift . . . . . . . . . . . . . . . 2039

C. The Crime Against Humanity and Contemporary Tyranny . . 2044

D. The Transitional Criminal Sanction . . . . . . . . . . . . 2049

III. Constitutional Justice . . . . . . . . . . . . . 2051

A. The Prevailing Models . . . . . . . . . . . . 2052

t Senior Schell Fellow, Yale Law School; Professor of Law, New York Law School. I would like to thank the Yale Law School Faculty Workshop (Spring 1996) for the opponunty to present and for valuable discussion of the constitutionalism portions of this Article. Portions of the Arucle also benefited from discussion at workshops at the University of Michigan. University of Connecucul. Cardozo, and New York Law Schools, and the American Philosophical Association Eastem Division Mecting. This Arucle is part of a larger work in progress on the conception of justice in penods of political transituon: RUTn TErrel. Transmional Justice (Oxford Univ. Press, forthcoming). My gratitude to Jack Balkin. Peter Berkowitz. Stephen Ellmann, Ryan Goodman, Rober Gordon. Paul Kahn, Harold Koh, Lamy Lessıg. Michel Rosenfeld, András Sajó, Tony Sebok, Reva Siegel, and Jonathan Stein for valuable comments I am graleful to the students of Human Rights in Transitional Regimes for helpful discussion of many of the ideas discussed herein. I am indebted to Camille Broussard of the New York Law School Lubrary and to my research assistants, Zoe Hilden and Derek Jinks, for superlative help in the research of this Arucle and for their advice. For translation assistance, I am thankful to Belinda Cooper. My grautude to Brenda DavisLebron for wordprocessing assistance. Suppon for the researching of this Article was provided by the Ernst Stiefel Fund at New York Law School, the United States Institute of Peace, the Foundation for a Civil Society, and the Orville H. Schell, Jr., Center for International Human Rights at Yale Law School. 
1. The Classical View . . . . . . . . . . . . . . . . . 2053

2. The Modern Claim . . . . . . . . . . . . . . . . . 2054

B. A Transitional Counteraccount ................ 2057

1. Brokering out of Authoritarian Rule . . . . . . . 2058

2. Victor's Constitutional Justice . . . . . . . . . . . . 2063

3. Velvet Revolutions and Their Constitutions . . . . . 2068

4. The American Constitution: A Transitional Account . . . . 2071

C. Transitional Constitutionalism: Some Conclusions ... . . . 2076

IV. A TRANSITIONAL JURISPRUdENCE . . . . . . . . . . . . . . . 2077

V. Conclusion ...................... 2080 
At a time of political movement from illiberal rule, questions of transitional justice remain largely unaddressed. How is the social understanding behind a new regime committed to the rule of law created? Which legal acts have transformative significance? What, if any, is the relation between a state's response to a repressive past and its prospects for creating a liberal order?

Debates about transitional justice are generally framed by the normative proposition that various legal responses should be evaluated on the basis of their prospects for democracy.' The prevailing approaches yield limited positive accounts that miss the particular significance of justice claims in periods of political change. Such theorizing also fails to explain the relationship between normative responses to past injustice and the prospects for liberal transformation. This Article attempts to move beyond prevailing theorizing to explore legal responses in periods of political transformation. It suggests that these legal responses play an extraordinary constituting role in such periods.

Within comparative political theory, the dominant approach is to explain a state's legal responses in terms of the political and institutional constraints of the transition. The dominant approach considers the search for justice an epiphenomenon, explained in terms of the balance of power. ${ }^{2}$ From the realist perspective, the question of why a given state response occurred is conflated with the question of what response was possible. ${ }^{3}$ Law is considered a product

1. See Bruce A. ACKerman, The future of Liberal Revolutton (1992): Carlos SaNthago Nino, Radical EvIl on Trlal (1996); John Herz An Hisioncal Perspective, in STate CRlmes: PUNISHMENT OR PARDON 11, 16 (Alice H. Henkin ed., 1989). The scholarly perspectuves on the question have tended to adopt either a response-sensitive approach or a regional approxch for comparatuve approaches, see the essays collected in TRANSITIONS FROM AUTHORTTARLAN RULE: COMPARATVE PERSPECTTVES (Guillermo O'Donnell a al. eds., 1986). See also JUAN J LaNz \& ALrRED STEPAN, PROBLEMS OF DEMOCRATIC TRANSTIION AND CONSOLIDATION (1996) (explonng processes of transition and consolidation from comparative perspective). Paricularly in response-sensituve approaches, there has been a substantial debate over punishment. See, e.g. Jame Malamud-Goll. Transitional Governments in the Breach: Why Punish State Criminals?, 12 HuM. RTs. Q. 1 (1990): infra nole 172 These responsesensitive approaches, however, like the country-sensiluve approaches, fall to caplure the scope and significance of the role of the law in transition contended for here.

Works that move beyond the case study or regional approach often confine themselves to a parucular historical moment. See, e.g., From DictaTORSHIP to DEMOCRACY: COPING WTTH THE LEGACtES OF AUTHORITARIANISM AND TOTALITARLANISM (John Herz ed., 1982) (focusing on postwar penod) For the classic inquiry into the question of political justice, sec OTTO KIRCHHEMER, POLIICAL JUSTICE: THE USE OF LEgAL PROCEDURE FOR POLTICAL ENDS (1961). Kirchheimer's classic exploration of politucal justice includes successor trials as an example of the phenomenon of politically mouvated justuce. See td. at 304-47.

2. The explanatory power of this scholarship goes to the question of why uransitional justuce is a vital issue in some countries, but not in others. See LiNz \& STEPAN, supra note 1. TKANSmoNs From AUTHORTARLAN RULE, supra note 1 (collecting essays that adopt primarily regional approach), see also

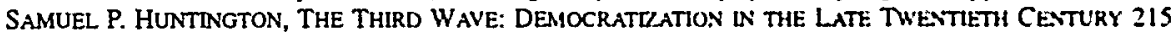
(1991); Stephen Holmes, The End of Decommunization, E. EUR CONST REV. Summer/Fall 1994, at 33

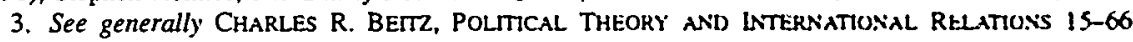
(1979) (discussing flaws of moral skepticism as appliod to state action): R.B J W ALKER, LNSIDE/OUTSIDE. INTERNATIONAL RELATIONS AS POLTICAL THEORY 123-24 (1993). For sound summanes of the realist school in intemational theory, see JOHN H. HERz, POLTICAL REALISM AND POLITICAL IDEALISM (195!), MARTIN WRIGHT, INTERNATIONAL THEORY: THE THREE TRADITIONS (1991); and J Ann Tickner. Hans Morgenthau's Principles: A Feminist Reformulaton, in INTERNATIONAL. THEORY Crmical. 
of political change. The path of the transition is thought to explain the prevailing balance of power, which in turn purportedly explains the legal response. However, to say that states do what they can does not explain the great diversity of transitional legal phenomena. To say states do what is possible, as in the realist account, conflates the descriptive account with its normative conclusions. ${ }^{4}$ The connection between a state's response to the transitional problem and its prospects for liberal transformation remain essentially unjustified. Nor is the idealist account satisfactory. From the idealist perspective, the question of transitional justice generally falls back upon universalist conceptions of justice. ${ }^{5}$ Yet this approach misses distinctive features of conceptions of justice in extraordinary periods of transition.

The realist/idealist antinomy on the relation of law to politics shares affinities with liberal/critical theorizing about law and politics. In liberal theorizing, law is commonly conceived as following idealist conceptions unaffected by political context, ${ }^{6}$ while critical legal theorizing, like the realist approach, emphasizes law's close relation to politics. ${ }^{7}$ Again, liberal/critical theorizing about the nature and role of law in ordinary times does not account well for law's role in periods of political change. ${ }^{8}$

Moving away from the prevailing approaches, adopting a largely inductive method, and exploring an array of legal responses, I describe a distinctive conception of law and justice in the context of political transformation. Several important legal responses discussed herein arise out of the contemporary wave of political change, including the transitions from Communist rule in Eastern and Central Europe and the former Soviet Union, as well as from repressive military rule in Latin America and Africa. Where relevant, I draw upon historical illustrations, from ancient times to the Enlightenment, from the French and American revolutions through the postwar and contemporary

INVESTIGATIONS 53, 55-57 (James Der Derian ed., 1995).

4. For such an argument, see HUNTINGTON, supra note 2, at 231.

5. See ACKERMAN, supra note 1, at 69-73; E.B.F. MidoleY, THE NATURAL LAW TRADITTON AND THE THEORY OF INTERNATIONAL RELATIONS 219-31, 350-70 (1975).

6. Liberal approaches predominate in theorizing in international law and politics. See Anne-Maric Slaughter Burley, International Law and International Relations Theory: A Dual Agenda, 87 AM. J. INT'L L. 205 (1993). The liberal tradition in jurisprudence informs these approaches. See, e.g., RoNALD DWORKIN, LAW'S EMPIRE (1986); RONALD DWORKIN, TAKINO RIGHTS SERIOUSLY (1978). See generally LIBERALISM AND THE GOOD (R. Bruce Douglass et al. eds., 1990) (discussing liberalism's commitment to neutrality). The paradigmatic expression of liberal theory's views on law and politics can be found in JOHN RAWLS, POLITICAL LIBERALISM (1993); and John Rawis, The Domain of the Political and Overlapping Consensus, 64 N.Y.U. L. REV. 233 (1989).

7. Prominent collections of critical legal studies (CLS) essays include JAMEs BOYLE, CRITICAL LEOAL

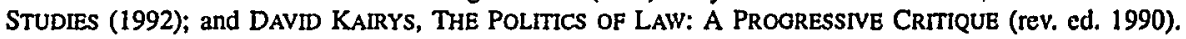

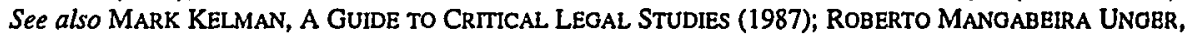
The CRITICAL Legal Studies Movement (1986); James Boyle, The Politics of Reason: Critical Legal Theory and Local Social Thought, 133 U. PA. L. REV. 685 (1985) (discussing legal realism, linguistic theory, and Marxist theory). For critical treatment of international legal issues, see Nigel Purvis, Critical Legal Studies in Public Intemational Law, 32 HARV. INT'L L.J. 81 (1991); and Phillip R. Trimble, International Law, World Order, and Critical Legal Studies, 42 STAN. L. REV. 811 (1990).

8. See infra notes $93-95$ and accompanying text. 
periods. I begin by rejecting the notion that the movement toward a more liberal democratic political system implies a universal norm. Instead, the Article offers an alternative way of thinking about the relation of law to political transformation. The interpretive inquiry proceeds on a number of levels. On one level, I attempt to provide a better account of transitional practices. Study of the law's response in periods of political change offers a positive understanding of the nature of accountability for past wrongs. On another level, I explore the normative relation between legal responses to repressive rule, conceptions of transitional justice, and our intuitions about the construction of the liberal state.

What might the study of legal responses following repressive rule tell us about the conceptions of justice in such periods? The central question of transitional justice arises within a distinctive context, a shift in political orders. "The "transitional" period begins right after the revolution or political change; thus, the problem of transitional justice arises within a bounded period, spanning two regimes. ${ }^{10}$ In the contemporary period, the use of the term "transition" has come to mean change in a liberalizing direction; accordingly, the transitions discussed here have a concededly normative direction. "In transitional periods, there are continuities among these legal responses. The next question is what rules of recognition govern transitions. Here, my aim is to shift the focus away from the traditional political criteria associated with liberalizing change to take account of other practices, particularly the nature

9. In focusing upon the stage of "transition," I choose to shift the terms of the vocabulary employed by prior constitutional theorists to analyze the rule of law in political change. They speak in terms of revolution and suggest that law's role comes in at the last stage of revolution. See ACKERsids. supra note 1, at 11-14; HANNAH ARENDT, ON REVOLUTION 139-78 (1963). Rather than an undefined last stage of revolution, the notion of transition is more capacious: It demareates a posurevoluuonary ume penod

10. See GULLLRMO O'DONNELL \& PHLLPPE C. SCHMITTER. TRANSmONS FROM AUTHORTARLAN RULE: TENTATTVE CONCLUSIONS ABOUT UNCERTAN DEMOCRACIES 6 (1986) (defining transition as the interval between one political regime and another"). Within political science. there is substantual debate about the meaning of the term "Yransition," and by implication its limiting stage, "consolidation " Withun one school of thought, "transition" is demarcated by objective political criteria, chiefly procedural un nalure For some time, the criteria for the transition to democracy have focused on clecuons and relaled procedures See JUAN J. LINZ, Totalitarian and Authoritarian Regimes, in HANDBOOK OF POLMICAL SCIENCE: MACROPOLITICAL. THEORY 182-83 (Fred I. Greenstein \& Nelson W. Polsby eds. 1975) For the classical articulation, see ROBERT DAHL, POLYARCHY 20-32, 74-80 (1971). Thus Samuel Huntangton's formulation, following Schumpeter, defines twentieth-century democratization to oocur when the "most powerful collective decision makers are selected through fair, honest and periodic elections " HuNTLiotos, supra note 2, at 7. For others, the transition ends when all the politically significant groups accept the rule of law See Richard Gunther et al., O'Donnell's 'Illusions': A Rejoinder. J. DewOCRACY. Oct. 1996, at 151. 153 Beyond this school are others that embrace a more teleological view of democracy The teleological approach has been challenged for incorporating a bias lowards western-style democracies For a crntuque of the teleological view, see Guillemo O'Donnell, Illusions and Conceprual Flans. J. DeslocracY, Oct. 1996, at 160, 163-64; and Guillermo O'Donnell, Illusions About Consolidarion, J. DEMOCRACY. Apr. 1996, at 34. See also HUNTINGTON, supra note 2, at 7-8.

11. For illustrations of this liberalizing trend, see generally From DICTATORSHIP TO DEMOCRACY, supra note 1, which describes the democratic transitions of West Germany. Italy. Austra. France. Japan. Spain, Portugal, and Greece. To date, political scientists have not incorporated this posiuve normatuve direction expressly in their definition of the term. I embrace the notion that the contemporary understanding of transition has a normative component of moving from less to more democratic regimes. 
and role of legal phenomena. ${ }^{12}$ I explore the phenomenology of transition to suggest that there is a close tie between the normative shift in understandings of justice and law's role in the construction of transition. ${ }^{13}$

Because transitional justice is justice within defined political parameters, it is limited and partial. Understanding the particular problem occasioned by the search for justice in the transitional context requires entering a distinctive discourse, organized by dilemmas inherent to these extraordinary periods. The threshold dilemma lies in the context of political transformation: Law is caught between the past and the future, between backward-looking and forwardlooking, between retrospective and prospective. Transitions imply paradigm shifts in the conception of justice; thus, law's function is inherently paradoxical. In its ordinary social function, law provides order and stability, but in extraordinary periods of political upheaval, law maintains order, even as it enables transformation. Ordinary predicates about law simply do not apply. In dynamic periods of political flux, legal responses generate a sui generis paradigm of transformative law.

The thesis of this Article is that the conception of justice in periods of political change is extraordinary and constructivist: It is alternately constituted by, and constitutive of, the transition. The conception of justice that emerges is contextual: What is deemed just is contingent and informed by prior injustice. Responses to repressive rule inform the meaning of adherence to the rule of law. As a state undergoes political change, legacies of injustice have a bearing on what is deemed transformative. To some extent, the emergence of these legal responses instantiates transition. ${ }^{14}$

I will explore the role of law in periods of political change by looking at three areas that most reflect law's transformative potential: the rule of law, criminal justice, and constitutional justice. Although these areas are generally thought to be discrete categories of the law, periods of political shift illuminate their affinities ${ }^{15}$ and reveal how the law's response in such periods defies the

12. The constructivist approach proposed by this Article suggests a move away from defining transitions purely in terms of democratic procedures, such as electoral processes, toward a broader inquiry into other practices signifying acceptance of liberal democracy and the rule of law. This inquiry examines the normative understandings, beyond majority rule, that are associated with liberal systems. This observation has implications for certain debates in political science and constitutionalism and may well share affinities with jurisprudential debates concerning what makes for the authority of law. See JOSEPH RAZ, THE AUTHORITY OF LAW 214 (1979); infra note 19.

13. Not all transformations exhibit the same degree of normative shift from preexisting legal understandings. One might conceptualize transitions in terms of their relation to the predecessor regime along a transformative continuum, as "radical" or "conservative" in nature. See infra note 255 and accompanying text (discussing American transition as conservative in nature).

14. As the discussion proceeds, it shall become evident that the law's role in periods of political change is complex. Ultimately, this Article makes two claims: one about the nature and role of law in periods of substantial political change, and another about law's role in constituting the transition. The association of these responses with periods of political change advances the construction of societal understanding that transition is in progress. See infra Part IV.

15. The most common alternative advocates punishment of the ancien régime as a necessary element in the transition to democracy. See infra notes 96-108 and accompanying text. 
usual categorization. These practices offer not only a way to delegitimate the political opposition, but also a form of legitimation of the present, more liberal, regime. ${ }^{16}$ In each Part, I will show how various legal responses in periods of substantial political change reflect similar developments in the law, enabling the construction of normative shifts. Adjudications of the rule of law reflect understandings of legitimacy; criminal justice establishes wrongdoing; and transitional constitutionalism defines the state's political identity-all in a liberalizing direction. The analysis proposed here illuminates a distinctive understanding of law's phenomenology in periods of political change, an understanding I term "transitional jurisprudence."

Part I concerns the rule of law in transition. In established democracies during ordinary times, adherence to the rule of law implies the operation of principles that constrain the purposes and application of the law. In periods of substantial political change, by contrast, the transitional dilemma means that the law is unsettled, and the rule of law is not well explained as a source of ideal norms in the abstract. From the perspective of transitional jurisprudence, the rule of law can be better understood as a normative value scheme elaborated in response to past political repression supported by the prior legal system. Transitional law is settled and unsettled. It is both backward- and forward-looking, as it disclaims past illiberal, and reclaims future liberal, norms.

Part II concerns criminal justice in transition. Successor trials have long been thought to play a foundational role in the transformation to a more liberal political order. Such trials draw a line demarcating the normative shift from illegitimate to legitimate rule. Yet the exercise of criminal power in times of substantial political change raises profound dilemmas. In the transitional context, the ordinary principle of individual responsibility for past wrongdoing is inapplicable, leading to the emergence of new criminal legal forms that may contribute to the construction of a liberal politics.

In Part III, I explore transitional constitutionalism. Transitional constitutionalism serves not only conventional constitutionalism's constitutive purposes, but also its transformative purposes. While in ordinary times constitutions are conceived as fully forward-looking, in periods of radical change such constitutions are simultaneously backward- and forward-looking, varying along a range of constitutional entrenchment. The values protected by transitional constitutionalism, criminal justice, and the rule of law share affinities in their normative relation to past political rule.

In Part IV, I bring together and analyze the various ways in which new democracies respond to legacies of injustice. A pattern of legal responses, this Article contends, reveals affinities in the nature and uses of the law, informing

16. Indeed, these practices facilitate construction of both an illegitumate opposition and a legumate political opposition associated with democratic order. 
the field of transitional jurisprudence. The analysis pursued here is constructivist, ${ }^{17}$ as it considers the transitional legal forms that emerge as a distinctive paradigm responsive to the extraordinary problem of law in periods of substantial political change. ${ }^{18}$ Analysis of these legal responses suggests that they defy traditional legal categorizations. In transitional jurisprudence, the conception of law is partial, contextual, and situated between at least two legal and political orders. Legal norms are necessarily multiple, the idea of justice always a compromise. In transitional jurisprudence, the nature and role of law centers upon its paradigmatic use in the normative construction of the new political regime.

This Article offers the language of a new jurisprudence rooted in prior political injustice. Conceiving of jurisprudence as transitional helps to elucidate the nature and role of law during periods of radical political change. By offering another way of conceptualizing law, transitional jurisprudence also has implications that transcend these extraordinary periods. The problem of justice during periods of political transformation has a potentially profound impact upon the resulting societal shift in norms and the groundwork for transformed constitutional and legal regimes. The unresolved problems of transitional justice often have lasting implications over a state's lifetime. I suggest a new perspective through which to understand the significance of the enduring political controversies that presently divide our societies.

\section{THE RULE OF LAW IN TRANSITION}

I now turn to an exploration of the various legal responses to illiberal rule. In this Part, I suggest that adherence to the rule of law during periods of political upheaval creates a tension between rule of law as backward-looking and forward-looking, as settled versus dynamic. In this dilemma, the rule of law is ultimately contingent; rather than grounding legal order, it serves to mediate the normative shift in justice that characterizes these extraordinary periods. In democracies in ordinary times, the rule of law means adherence to

17. For a useful introduction to this constructivist approach, see PETER L. BERGER \& THOMAS LUCKMANN, THE SOCLAL CONSTRUCTION OF REAIITY 19 (1966), which describes the approach from a sociological perspective. On constructivism in the law, see Pierre Bourdieu, The Force of Law: Towards a Sociology of the Juridical Field, 38 HASTINGS L.J. 805, 814-40 (1987). See also ROBERTO MANOABEIRA UNGER, FALSE NECESSITY 246-51 (1987) (analyzing legal and institutional responses to "context change"). For a subtle treatment of the role of law in constructing community, see Robert Gordon, Critical Legal Histories, 36 STAN. L. REV. 57 (1984). See generally JOHN BRIOHAM, THE CONSTITUTION OF INTERESTS (1996) (discussing law's role in constructing political movements).

18. By use of the term "legal forms," I mean principles, norms, ideas, rules, practices, as well as the agencies of legislation, administration, adjudication, and enforcement. See SALLY FALK MOORE, LAW AS PROCESS 54 (1978). On the significance of legal forms, see Isaac D. Balbus, Commodity Form and Legal Form: An Essay on the "Relative Autonomy" of the Law, 11 L. \& SoC'Y REV. 571, 571-72 (1977). Bcyond the legal forms discussed here are others explored in my forthcoming book, TRANSITIONAL JUSTICB. See TEITEL, supra note $\dagger$. 
known rules, as opposed to arbitrary government action. ${ }^{19}$ Yet revolution implies disorder and legal instability. The threshold dilemma of transitional justice is the problem of the rule of law in periods of radical political change. By their very definition, these are often times of massive paradigm shifts in understandings of justice. Here societies are struggling with how to transform their political, legal, and economic systems. If ordinarily the rule of law means adherence to settled law, to what extent are periods of transformation compatible with commitment to the rule of law? In such periods, what does the rule of law mean?

The dilemma of the meaning of the rule of law transcends the moment of political transformation and goes to the heart of the basis for a liberal state. Even in ordinary periods, stable democracies struggle with questions about the meaning of adherence to the rule of law. Versions of this transitional rule-oflaw dilemma are manifest in problems of successor justice, constitutional beginnings, and constitutional change. ${ }^{20}$ The rule-of-law dilemma tends to arise in politically controversial areas, where the value of legal change is in tension with the value of adherence to the principle of settled legal precedent. In ordinary periods, the problem of adherence to legal continuity is created by the passage of time. ${ }^{21}$ In transformative periods, however, the value of legal

19. See F.A. HAYEK, THE ROAD TO SERFDOM 72 (1944) ("[G]ovemmenl in all its actions is bound by rules fixed and announced beforehand-rules which make it possible to foresee with faur centunty how the authority will use its . . powers in given circumstances and to plan one's undividual affaurs on the basts of this knowledge."). For a discussion of the general understanding of the role of rule of law in democracies as restraint on arbitrary power, see ROGER COTTERRELL. THE POLITICS OF JURISPRUDENCE 113-14 (1989), which describes the danger of viewing the state as an entily above the law For an exploration of the relation of rule of law to democracy, see Jean Hampton. Demacracy and the Rule of Law, in NOMOS XXXVI: THE RULE OF LAW 13 (lan Shapiro ed., 1994). The classic account of the minimum requirements of legality is found in LON L. FULLER. THE MORNLTY OF LAW 33-94 (reV ed. 1969). Ronald Dworkin offers the most prominent contemporary exposition of substanlive rule-of-law theory. See RONALD DWORKIN, A MATTER OF PRINCIPLE 11-12 (1985) (arguing that "nghts conscption" of rule of law "requires, as part of the ideal of law, that the rules in the rule book capture and enforce moral rights"); see also Frank Michelman, Law's Republic, 97 YALE L.J. 1.93 (1988) (presentung modem interpretation of government by law through reinterpretation of political theory of civic republicanism)

Margaret Jane Radin describes the philosophical underpinning of modern approaches to the rule of law as consisting of the following assumptions:

(1) law consists of rules; (2) rules are prior to particular cases, more general than parucular cases, and applied to particular cases; (3) law is instrumental (the rules are applied to achieve ends); (4) there is a radical separation between government and citizens (there are rule-givers and appliers, versus rule-takers and compliers); (5) the person is a rational chooser ordering her affairs instrumentally.

Margaret Jane Radin, Reconsidering the Rule of Law, 69 B.U. L. Rev. 781,792 (1989). See generally COTTERRELL, supra (providing introduction to debate about nature of law); THE RULE of LAW (Allan C. Hutchinson \& Patrick Monahan eds., 1987) (collecting several essays discussing rule of law): Roger Cotterrell, The Rule of Law in Corporate Socien: Neumann, Kirchtheimer and the Lessons of Wetmar, SI MOD. L. REV. 126, 126-32 (1988) (book review) (discussing British concepts of rule of law)

20. For an early discussion of the common themes in the concepts of the rule of law and of constitutionalism, see A.V. DICEY, INTRODUCTION TO THE STUDY OF THE LAW OF THE CONSTITUTION 107-22 (8th ed. 1915). See also E.P. THOMPSON. WHIGS AND HUNTERs (1975) (discussing ongin of Black Act). The commonalities in the transitional form of these concepts are discussed below. See infra Part IV

21. The ideal of the rule of law as legal continuity is captured in the principle of stare decisis, a predicate of adjudication in the Anglo-American legal system. See Planned Parenthood v Cascy. 505 U S 833,854 (1992) ("[T]he very concept of the rule of law underlying our own Constitution requires such 
continuity is severely tested. The question of the normative limits on legitimate political and legal change for regimes in the midst of transformation is frequently framed in terms of a series of antinomies. The law as written is compared to the law as right, positive law to natural law, procedural to substantive justice, and so forth.

My aim is to resituate the rule-of-law dilemma by exploring societal experiences that arise in the context of political transformation. My interest is not in idealized theorizing about the rule of law in general. Rather, I attempt to understand the meaning of the rule of law for societies undergoing massive political change. This Part approaches the rule-of-law dilemma in an inductive manner by resituating the question as it actually arises in its legal and political contexts. It explores a number of historical postwar cases, as well as precedents arising in the more contemporary transitions. Although the rule-oflaw dilemma arises commonly in the criminal context, the issues raise broader questions about the ways in which societies in periods of intense political change reason about the relation of law, politics, and justice. As shall become evident, these adjudications reveal central ideas about the extraordinary conception of the rule of law, and of values of justice and fairness in periods of political change. ${ }^{22}$

\section{A. The Rule-of-Law Dilemma: The Postwar Transition}

In periods of political change, a dilemma arises over adherence to the rule of law that relates to the problem of successor justice. To what extent does bringing the ancien régime to trial imply an inherent conflict between predecessor and successor visions of justice? In light of this conflict, is such criminal justice compatible with the rule of law? The dilemma raised by successor criminal justice leads to broader questions about the theory of the nature and role of law in the transformation to the liberal state.

The transitional dilemma is present in changes throughout political history. It is illustrated in the eighteenth-century shifts from monarchies to republics, but has arisen more recently in the post-World War II trials. In the postwar period, the problem was the subject of a well-known Anglo-American jurisprudential debate between Lon Fuller and H.L.A. Hart, who took as their point of departure the problem of justice after the collapse of the Nazi regime. ${ }^{23}$ Such postwar theorizing demonstrates that in times of significant

continuity over time that a respect for precedent is, by definition, indispensable."); see also Antonin Scalia, The Rule of Law as a Law of Rules, 56 U. CHI. L. REv. 1175 (1989) (advocating "general rule of law" over "personal discretion to do justice").

22. See infra notes $51-75,93-95$, and accompanying text.

23. See H.L.A. Hart, Positivism and the Separation of Law and Morals, 71 HARV. L. REV. 593 (1958) (defending positivism); Lon L. Fuller, Positivism and Fidelity to Law-A Reply to Professor Hart, 71 HARV. L. REV. 630 (1958) (criticizing Hart for ignoring role of morality in creation of law). 
political change, conventional understandings of the rule of law are thrown into relief. ${ }^{24}$ Although the transitional context has generated scholarly theorizing about the meaning of the rule of law, that theorizing does not distinguish understandings of the role of law in ordinary and transitional times. Moreover, the theoretical work that emerges from these debates frequently falls back on grand, idealized models of the rule of law. Such accounts fail to recognize the exceptional issues involved in the domain of transitional jurisprudence. ${ }^{25}$

The Hart-Fuller debate on the nature of law focuses on a series of cases involving the prosecutions of Nazi collaborators in postwar Germany. The central issue for the postwar German courts was whether to accept defenses that relied on Nazi law. ${ }^{26}$ A related issue was whether a successor regime could bring a collaborator to justice, and if so, whether that would mean invalidating the predecessor laws in effect at the time the acts were committed. ${ }^{27}$ Hart, an advocate of legal positivism, ${ }^{23}$ argued that adherence to the rule of law included recognition of the antecedent law as valid. Prior written law, even where immoral, should retain legal force and be followed by the successor courts until such time as it is replaced. In the positivist position advocated by Hart, the claim is that the principle of the rule of law governing transitional decisionmaking should proceed-just as it would in ordinary times-with full continuity of the written law.

In Fuller's view, the rule of law meant breaking with the pnor Nazi legal regime. As such, Nazi collaborators were to be prosecuted under the new legal regime: In the "dilemma confronted by Germany in seeking to rebuild her shattered legal institutions ... . Germany had to restore both respect for law and respect for justice.... [P]ainful antinomies were encountered in attempting to restore both at once ...."29 According to the German judiciary,

24. Other theorizing about the nature of the rule of law in the works of Frane Neumann and Otto Kirchheimer also takes this period as its point of departure See KIRCHHELMER, supra note 1, al 323-i1.

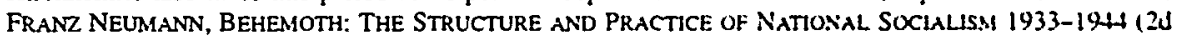
ed. 1944); Franz NeumaNN, The RUle of LAW (1986) |hereinafter NeumakN. The RlLe ur LaW]. The RULE OF LAW UNDER SIEGE: SELECTED ESSAYS OF FrANZ L NEUMANN \& OTTO KIRChiHEIMER (WIllum E. Scheuerman ed., 1996) (hereinafter THE RULE OF LAW UNDER SiEGE] For an enguging exposituon ot the views of these scholars, see WILLIAM E. SCHEUERMAN, BETWEEN THE NORM AND THE EXCEPTUN THE FRANKFURT SCHOOL AND THE RULE OF LAW (1994), which altempls to apply Neumann and Kurchheimer's analysis to the twentieth-century capitalist welfare state

25. Recognition of a domain of transituonal jurisprudence nevertheless rases again the ussue of the relation of the exceptional rule of law to that in ordinary periods This issue is only rased here, but is more fully addressed in my forthcoming book, Transitonal Jusnce See TEITEl, supra nute $\mathrm{I}$

26. See Recent Cases, 64 HARV. L. Rev 996, $1005-06$ (1951) (cutung Judgment ut July 27, 1949. Oberlandesgericht [OLG] (Bamberg), 5 SODDEUTSCHE JURISTEN ZtTUNO 207 (1950) (F R G ),

27. In the "Problem of the Grudge Informer," the issue rased in Bomberg is set uut in $\perp$ hyputhetical somewhat abstracted from the postwar situation: The so-culled Purple Shin regime has been uverthrown and replaced by a democratic constitutional government. and the question is whether to punish thuse who had collaborated in the prior regime. See FuLLER, supra nole 19. app at 245

28. For a thoughtful exploration of the meaning of legal posituvism. see Fredenck Sthauer. Fuller's Internal Point of View, 13 LAW \& PHIL. 285 (1994)

29. See Fuller, supra note 23, at 657. Whereas the rule-of-law dichotomy was tramed in terms of 
there is a dichotomy within the rule of law between the procedural legal right and the moral right. In "severe cases," the moral right takes precedence. Accordingly, formalist concepts of the law, such as adherence to putative prior law, could be overridden by such notions of moral right. The natural law position espoused by the German judiciary suggests that transitional justice necessitates departing from prior putative law. ${ }^{30}$

The above debate failed to focus, however, on the distinctive problem of law in the transitional context. In the postwar period, this dilemma arose as to the extent of legal continuity with the Nazi regime: To what extent did the rule of law necessitate legal continuity? A transitional perspective on the postwar debate would clarify what is signified by the rule of law. That is, the content of the rule of law is justified in terms of distinctive conceptions of the nature of injustice of the prior repressive regime. The nature of this injustice affects consideration of various alternatives, such as full continuity with the prior legal regime, discontinuity, selective discontinuities, or moving outside the law altogether. For positivists, full continuity with the prior legal regime is justified by the need to restore belief in the procedural regularity that was deemed missing in the prior repressive regime; the meta-rule-of-law value is due process, understood as regularity in procedures and adherence to settled law. The natural law claim for legal discontinuity is also justified by the nature of the prior legal regime, but according to the conceptualization of past tyranny: ${ }^{31}$ The predecessor regime's immorality suggests that the rule of law should be grounded in something beyond adherence to preexisting law.

To what extent is adherence to the laws of a prior repressive regime consistent with the rule of law? Conversely, if successor justice implied prosecuting behavior that was lawful under the prior regime, to what extent might legal discontinuity instead be mandated by the rule of law? The transitional context fuses these multiple questions of the legality of the two regimes and their relationship to each other.

In the postwar debate, both natural law and positivist positions took as their point of departure certain presumptions about the nature of the prior legal regime under illiberal rule. ${ }^{32}$ Both positions draw justificatory force from the role of law in the prior regime; nevertheless, they differ as to what constitutes

procedural versus substantive ideas of justice, Fuller tries to elide these competing conceptions by proposing a procedural view of substantive justice. See id. at 642-43.

30. For Fuller, however, it would not imply such a break because past "law" would not qualify as such for failure to comply with various procedural conditions. See FULLER, supra note 19, at 96-97.

31. See Gustav RADBRUCH, RECHTSPHILOSOPHIE (1956); Gustav Radbruch, Die Erneurung des Rechts, 2 DIE WANDLUNg 8 (1947); see also Markus Dirk Dubber, Judicial Positivism and Hitler's Injustice, 93 COLUM. L. REV. 1807 (1993) (reviewing INGO MOLLER, HITLER's JUSTICE (1991)). On the natural law position on the rule of law, Fuller's position appears more nuanced as it attempts to offer a procedural understanding of substantive justice values. See Fuller, supra note 23.

32. For an excellent account of this historical debate, see Stanley L. Paulson, Lon L. Fuller, Gustav Radbruch, and the "Positivist" Thesis, 13 LAW \& PHIL. 313 (1994). 
a transformative principle of legality. The positivist argument attempts to divorce questions of the legitimacy of law under predecessor and successor regimes. The response to past tyranny is thought not to lie in the domain of the law at all, but instead in the domain of politics. If there is any independent content given to the rule of law, it is that it ought not serve transient political purposes. The positivist argument for judicial adherence to settled law, however, relies on assumptions about the nature of legality under the predecessor totalitarian regime. ${ }^{33}$ The justification for adhering to prior law in the transitional moment is that under prior repressive rule, adjudication failed to adhere to settled law. On the positivist view, transformative adjudication that seeks to "undo" the effect of notions of legality supporting tyrannical rule would imply adherence to prior settled law.

The natural law position highlights the transformative role of law in the shift to a more liberal regime. On this view, putative law under tyrannical rule lacked morality and hence did not constitute a valid legal regime. ${ }^{34}$ Insofar as adjudication followed such putative law, it too was immoral in supporting illiberal rule..$^{35}$ From the natural law perspective, the role of law in transition is to respond to evil perpetuated under the past administration of justice. Because of the role of judicial review in sustaining the repression, ${ }^{36}$ adjudication as in ordinary times would not convey the rule of law. This theory of transformative law promotes the normative view that the role of law is to transform the prevailing meaning of legality. ${ }^{37}$

In the postwar debate, the questions arose in the extraordinary political context following totalitarian rule. Yet the conclusions abstract from the context and generalize as if describing essential, universal attributes of the rule of law, failing to recognize how the problem is particular to the transitional context. Resituating the problem should illuminate our understanding of the rule of law. I now turn from the postwar debate to more contemporary instances of political change illustrating law's transformative potential. Those instances exemplify the tension between idealized conceptions of the rule of law and the contingencies of the extraordinary political context. Struggling with the dilemma of how to adhere to some commitment to the rule of law in such periods leads to alternative constructions, constructions that mediate concepts of transitional rule of law.

33. See Har, supra note 23 , at $617-18$.

34. To some extent, in this normative legal theory, collapsing law and morality, the transitional problem of the relation between legal regimes disappears.

35. Thus the cases of the informers are characterized as "perversions in the administratuon of justuce." See FULLER, supra note 19, app. at 245.

36. This topic was discussed in the Hart-Fuller debate. See supra note 23: see also MOLLER. supro note 31.

37. See Fuller, supra note 23, at 648. 


\section{B. Shifting Visions of Legality: Post-Communist Transitions}

The velvet revolutions' rough underside has been revealed in courts of law, where debates about the content of the political transformation continue to simmer. A number of controversies over successor criminal justice exemplify the transitional rule-of-law dilemma. In this Section, I focus on two: In the first case, a Hungarian law allowed prosecutions for offenses related to the brutal Soviet suppression of the country's uprising in $1956 ;^{38}$ in the other, unified Germany prosecuted its border guards for shooting civilians who were attempting to make unlawful border crossings along the Berlin Wall. ${ }^{39}$ Both cases involve weighty symbols of freedom and repression: 1956 is considered the founding year of Hungary's revolution, while the Berlin Wall and its collapse is the region's central symbol of Soviet domination and demise. Both cases illustrate the dilemmas implied in the attempt to effect substantial political change through and within the law. Although the two cases seemingly suggest diverging resolutions of the rule-of-law dilemma, they also reveal common understandings.

After the political changes of 1991, Hungary's Parliament passed a law permitting the prosecution of crimes committed by the predecessor regime in putting down the popular 1956 uprising. Despite the passage of time since these crimes were committed, the law would have lifted statutes of limitations for treason and other serious crimes, ${ }^{40}$ effectively reviving these offenses. ${ }^{41}$ The controversy over the statute of limitations law raised a broader question: To what extent are successor regimes bound by prior regime law?

The Constitutional Court described the dilemma in terms of familiar antinomies: the rule of law understood as predictability versus the rule of law understood as substantive justice. So framed, the choices seemed irreconcilable; the statute of limitations law and the proposed 1956-era prosecutions were held unconstitutional. The principle of the rule of law required prospectivity in

38. See Zentenyi-Takacs Law, Law Concerning the Prosecutability of Offenses Between December 21, 1944 and May 2, 1990 (Nov. 4, 1991) (Hung.), translated in 1 J. CONST. L. E. \& CENT. EUR. 131 (1994) [hereinafter Zentenyi-Takacs Law]; see also Stephen Schulhofer et al., Dilemmas of Justice, E. EuR. CONST. REV., Summer 1992, at 17.

39. See infra notes $46-49$ and accompanying text.

40. See Zentenyi-Takacs Law, supra note 38.

41. Similar legislation reviving the time bars elapsing during the Communist regime was also enacted elsewhere in the region, as in the Czech Republic. See Decision of Dec. 21, 1993, Const. Ct. Czech Rep. (on file with Center for the Study of Constitutionalism in Eastern Europe, Univ, of Chicago) (upholding Act No. $198 / 1993 \mathrm{Sb}$. Regarding the Lawlessness of the Communist Regime and Resistance to It) [hereinafter Decision on Act. No. 198/1993 Sb.]. The problem of statute of limitations laws commonly arises after long occupations when societies attempt to prosecute crimes committed under predecessor regimes. Thus, in Western Europe, the rule-of-law problem posed by the passing of statutes of limitations would not arise in the immediate postwar period, but only later in the 1960s. For discussion of Germany's statute of limitations debate, see ADALBERT ROCKERL, THE INVESTIOATION OF NAZI CRDES 1945-1978, at 53-55, 66-67 (1980). See also infra notes $136,158$. 
lawmaking, even if it meant the worst criminal offenses of the prior regime would go unpunished. ${ }^{42}$

The dominant vision of the rule of law for the Constitutional Court was "security." "Certainty of the law demands... the protection of rights previously conferred ...." The proposed law, which would have opened the way to ancien régime prosecutions, was classically ex post and as such threatened individual rights to repose. In its discussion of the meaning of security, the Court analogized the right of repose at issue to personal property rights. Although protection of personal property rights could generally be overridden by competing state interests, such interests, the Court maintained, ought not override an individual's criminal process rights to repose. By protecting the rule-of-law value of "security" from invasion by the state, the Constitutional Court sent an important message that property rights would be protected in the transition.

In ordinary times, the idea of the rule of law as security in the protection of individual rights is frequently considered to be a threshold, minimal understanding of the rule of law basic to liberal democracy. ${ }^{\text {is }}$ Yet in the economic and legal transitions of Eastern and Central Europe, this understanding represents a profound transformation. If the totalitarian legal system abolished or ignored the line between the individual and the state, the line drawn by the Hungarian Court posited a new constraint on the state: an individual right of security. Insistence on the protection of individual rights, said to be previously acquired, was constructed in the transition. This sent an important message that the new regime would be more liberal than its predecessor.

Compare a second case. In its second round of successor cases in this century, Germany's judiciary once again confronted the transitional rule-of-law dilemma when East German border guards were put on trial for Berlin Wall shootings that occurred prior to Unification. ${ }^{46}$ The question before the Cour was whether to recognize defenses that relied upon predecessor regime law. ${ }^{47}$

42. The opinion begins with a statement of the Courts characterization of the dilemma it confronted "The Constitutional Court is the repository of the paradox of the revolution of the rule of law Constitutional Court of the Hungarian Republic Resolution No. 11/1992 (III.5) AB. rranslated in I J CONST. L. E. \& CENT. EUR. 129, 138 (1994). Why a paradox? "Rule of law," the Court sand, means "predictability and foreseeability." Id. at 141. "From the principle of predictabilaty and foresceabulity. the criminal law's prohibition of the use of retroactive legislation. especially ex post facto . dureculy follows . . . Only by following the formalized legal procedure can there be valid law . . Id at $141-12$.

43. See id. at 142 ("The certainty of the law based on formal and objecuve pnnciples is more important than necessarily partial and subjective justice.").

44. Id. at 136.

45. See F.A. HAYEK, THE CONSTITUTION OF LIBERTY 19-21 (1960).

46. On the legal and political changes in post-Communst Germany. see generally GeruAN UNIFICATION: PROBLEMS AND PROSPECTS (Gaines Post, Jr. od.. 1992): and Wiktor Ostalynskı, Revolutions in Eastern Europe, 58 U. CHI. L. REV. 823 (1991).

47. According to the former German Democratic Republic's Border Protection Lat, soldiers were authorized to shoot in response to acts of unlawful border crossing. The custom al the border was to enforce the law strictly. Supervisors emphasized that a breach of the border should be prevented "in all 
The Berlin Trial Court framed the dilemma in terms of the tension between "formal law" and "justice," and rejected former East German law because not everything is right which is law. ${ }^{48}$ Comparing the Communist laws to those of the Nazi period, the Court relied on postwar precedents holding that evil legislation lacked the status of law: "Especially the time of the National Socialist regime in Germany taught that ... in extreme cases the opportunity must be given for one to value the principle of material justice more highly than the principle of legal certainty ...."49 Procedurally, legal rights were distinct from moral rights. Characterized as "extreme cases," the border guards cases were analogized to those of the postwar collaborators and accordingly guided by the same adjudicative principle.

The transitional courts of Eastern and Central Europe, despite facing different legal issues, face a problem common to successor regimes: What are the rule-of-law implications of prosecuting for actions that were legal under the prior regime? As the earlier postwar debate suggests, this question really raises two questions, one about the legitimacy of law in both predecessor and successor periods, and another about the relation between the two. The juxtaposition is always between the rule of law as settled norms versus the rule of law as transformative. In the contemporary cases, as in the postwar debate, what emerges are new transitional understandings of the rule of law. Considered together, the two decisions present an interesting puzzle. For the Berlin court, the controlling rule-of-law value was what was "morally" right, whereas for the Hungarian Court the controlling rule-of-law value was protection of preexisting "legal" rights..$^{50}$ In one case, the rule of law requires security understood as prospectivity, with the consequence of forbearance in the criminal law. In the other view, justice is understood as equal enforcement of the law. Can the two cases be reconciled?

Probing the language of the successor cases exposes a conception of the rule of law peculiar to the transitional moment. Judicial rhetoric conceptualizes

cases and, if necessary, by all means." See Border Guards Prosecution Case, Bundesgerichtshof [BGH] (F.R.G.), translated in 100 I.L.R. 366, 370 (1995) (citing to Border Law (former G.D.R.)).

48. As the trial court stated:

In an examination of the question of whether it is permissible to threaten with death and, when necessary, even to kill the person who does not want to obey the prohibition on leaving, and who-disregarding it-wants to cross the border, the question presents itself whether everything is right that is formally and interpretatively considered a right.

Judgment of Jan. 20, 1992, Landgericht [LG] (Berlin), 13 JURISTEN ZETTUNO 691, 692 (1992) (F.R.G.); see also Judgment of Oct. 24, 1996, Bundesverfassungsgericht [BVerfGE] (F.R.G.) <http:www.uniwuerzburg.de/glaw/bvr94185.html> (visited Mar. 26, 1997) ("The violation is so serious that it violates the legal convictions common to all nations regarding the value and dignity of the human being. For such a case, positive law must give way to justice.").

49. Judgment of Jan. 20, 1992, Landgericht [LG] (Berlin), 13 JURISTEN ZEITUNo at 693 (quoting Bundesverfassungsgericht [BVerfGE] 3, 232 (1953) (F.R.G.)).

50. In exploring the term Rechtstaat the Hungarian Court suggested that it was guided by German understandings, but it did not appear to consider itself bound by the precedents informing the German judiciary's understanding of the rule of law in "extreme cases." See Constitutional Court of the Hungarian Republic Resolution No. 11/1992 (III.5) AB, translated in 1 J. CONST. L. E. \& CENT. EUR. 129 (1994). 
the problem in terms of multiple competing rule-of-law values in seemingly intractable conflict: one value deemed relative, and the other essential. The transitional judiciaries in these cases characterized the dilemma they confronted as involving a balancing of two senses of the rule of law: the rule of law as it is ordinarily understood versus a transformative understanding. Which of these values will dominate the transitional balance will depend on distinctive historical and political legacies. Accordingly, after totalitarianism, the dominant vision of the rule of law in Hungary is to draw a thin line of positive security upon which individuals can rely and which is beyond the reach of state power. In unified Germany, the transitional rule of law is defined within a preexisting jurisprudence, which continues to respond to legality under fascism. ${ }^{31}$ After Nazi rule, where a repressive security apparatus functioned outside the law and the legal machinery was itself used to persecute, the dominant sense of the rule of law was of equal protection in the administration of justice. These are transformative understandings.

Despite idealist theorizing to the contrary, the transitional precedents suggest that no one rule-of-law value is essential in the movement toward construction of a more liberal political system. Transcendent notions of rule-oflaw values in transitional societies depend in part on their distinctive political legacies, and in particular, on the role of law in the predecessor regime. ${ }^{52}$ The meaning of the rule of law is contingent in nature and constructed in part in relation to the social understanding of the response to injustice. ${ }^{53}$ Whereas the

51. When the German judiciary ruled that the border guard case constituted an "extreme case," " analogized Communist rule to that of National Socialism. In this way, the legal response to World War II injustice continued to guide contemporary adjudication in the transiuons out of Communist rule. As in the postwar period, the Court invoked overriding principles of natural law. See supra notes 31, 34, 35, and accompanying text.

52. There has been a lively scholarly debate on this question, and recent comparauve work concerning the role of adjudication under repressive rule in Germany under Nazi control. Laun Amenca under multary rule, and South Africa under apartheid rule. Despite substantial theonzing about the potental role of positivist and natural law adjudicative principles under prior tyrannical rule, to the extent that there has been empirical study of the judiciary's role in repressive periods, neither principle of adjudicauon appears to correlate with greater rule of law in such periods. In varying contexts. scholars have coneluded thal variations in interpretive strategies whether of positivist or natural law do not well explain the judictary's role under repressive rule.

Compare MOLLER, supra note 31, at 68,71-73 (clauming Nazu judges' free-ranging principle of interpretation led to suppon of repressive rule), with Dubber, supra note 31, at 1819-20, 1825 (observing that jurisprudence of this era included positivism, particularly where understood as separation of law and morality). For a thoughtful discussion, see Symposium. Nazis in the Courtroom: Lessons from the Conduct of Lawyers and Judges Under the Laws of the Thind Reich and Vichy France, 61 BROOK. L. REV 1121. 1142-45 (1995). For a discussion reganding South Africa, sOC DAVID DYZENHAUS. HARD CASES Di WICKEO LEGAL SYSTEMS: SOUTH AFRICAN LAW IN THE PERSPECTIVE OF LEGAL PHLLOSOPHY (1991): and STEPHEN ELLMANN, IN A TIME OF TROUbLE: LAW AND LIBERTY IN SOUTH AFrICA's STATE OF EMERGeNCY (1992) For a discussion of the Latin American judiciary's interpretive strategies, see Mark J Osiel. Dialogue wuh Dictators: Judicial Resistance in Argentina and Brazil, 20 L. \& SOC. LNQUtRY 481 (1995).

53. The transitional perspective on the meaning of the rule of law urged here sheds light on the puzzling gulf between American and Continental philosophers over the putative assoctations of vanous legal philosophies with repression and, conversely, with liberal rule. The fact this posituvism is associated with repression or liberal rule on opposite sides of the ocean suggests a contingent and transituonal response to its use by evil judges. In the United States, positivism is frequently associated whih junsprudence 
conventional understanding of the conception of tyranny is the lack of rule of law as arbitrariness, the transitional rule of law in the modern cases illuminates a distinctive normative response to contemporary tyranny. ${ }^{54}$ Where persecution was systematically perpetrated under legal imprimatur, ${ }^{5 s}$ the transitional legal response is the attempt to undo these abuses under the law.

\section{Transitional Constructions of Legality}

The above discussion leads to a more differentiated understanding of the rule of law in two senses, ordinary and extraordinary, and it illuminates an understanding of legality that is distinctively transitional. These understandings of the rule of law bridge the discontinuity from illiberal to liberal rule; as such, one might consider these values and processes to mediate the transition. I focus on three such mediating concepts in the discussion that follows. These are the social construction of the rule of law, the role of international law in transcending domestic legal understandings, and, finally, the core rule of law value: to transcend the passing politics of the time.

\section{The Role of Social Construction}

One mediating concept of the transitional rule of law is its social construction. What matters in establishing the rule of law is legal culture, not abstract or universal ideals of justice. ${ }^{56}$ The socially constructed understanding of the transitional rule of law is evident in the post-Communist adjudications. In the border guards case, ${ }^{57}$ the prevailing social understanding of law was used to justify the rejection of prior legal defenses. The validity of prior law depended on the social practices of the time, such as the norm's publication and transparency. ${ }^{58}$ "In the then-GDR, too, justice and humanity

upholding a slavery regime, whereas in Germany it is not positivism but natural law interpretation that is associated with the Reich judiciary. For a comparison of the American and English approaches, see Anthony J. Sebok, Misunderstanding Positivism, 93 MICH. L. REv. 2054, 2055 (1995); for an analysis of jurisprudence under a slavery regime, see ROBERT M. COVER, JUSTICE ACCUSED 26-29, 121-23 (1975); for a discussion regarding Nazi jurisprudence, see MOLLER, supra note 31.

54. From its inception in the ancient understanding termed "isonomy," the idea of the rule of law emerges in response to tyranny. In ancient times, isonomy is forged in response to tyranny understood as arbitrary and partial enforcement of the law. Because prior tyranny is associated with lawmaking that is both arbitrary and unequal, the ancient understanding of rule of law comprehended both values of security in the law and equal enforceability of the law. As in ancient times, the contemporary idea of rule of law is forged in the context of the move from repressive to more liberalizing rule. For an account of the history, see F.A. HAYEK, THE CONSTITUTION OF LIBERTY 162-75 (1960). For an intellectual history of the German Rechtstaat, see STEven B. SMITH, HEgEL's CRITIQUE OF LiBERALISM 145-48 (1989).

55. For a related discussion of tyranny in the form of systemic persecution, beyond the protection of the law, see JUDITH SHKLAR, LEgalisM: LAW, MORALS, AND POLITICAL TRIALS 126-27 (1964).

56. See HenRY W. EhrmanN, Comparative Legal Cultures 48-50 (1976); James L. Glbson \& Gregory A. Caldeira, The Legal Cultures of Europe, 30 L. \& Soc'Y REv. 55, 55-62 (1996).

57. See supra notes $47-49$ and accompanying text.

58. On one such articulation of the conditions for law, see Fuller, supra note 23, at 638-43. See also 
were illustrated and represented as ideals. In this respect, generally sufficient conceptions of the basis of a natural lawfulness were set out." 59 The border policy, which was generally secret and covered up whenever foreigners were in the country, lacked the transparency ordinarily associated with law..$^{60}$ The guards stood at a geographical and juridical border. This treatment signaled an illegitimacy of regulation of the border in its legal culture. A similar concem animated Hungary's Constitutional Court when it emphasized the rule-of-law value of security as continuity in the law. In the transitional context of political upheaval, the judiciary constructed the understanding of legal continuity. The perception of rule of law is created by the Court's own adherence to procedure. $^{61}$

What makes law positive? Prevailing theorizing about the rule of law posits that among the conditions for law is that it be known. ${ }^{62}$ Is knowledge of law equated with publication? In transitional periods, there is commonly a large gap between the law as written and as perceived. What makes law positive is the popular perception in the public sphere. This understanding broadens, indeed democratizes, sources of legality with societal involvement in the construction of legal culture. Indeed, in the contemporary media age, at any one time there may well be multiple sources of law, as well as numerous forms of publication, that overshadow the written law. ${ }^{63}$ Social understanding in the public sphere is a rule of recognition by which to evaluate the legal systems of illiberal regimes, an understanding of law that stands independent of the sovereign's decrees and as such is less affected by political upheaval. Guided by this mediating principle of transitional legality, the legitimacy of predecessor regime law would depend on popular understandings of legality in the ambient culture.

Understanding the rule of law as socially constructed offers a principle for evaluating legality in periods of movement between dictatorships and democracies. Recognition of a legitimacy gap between the law as written and as socially perceived offers a useful way to explain law's construction under illiberal rule. Indeed, as public belief in prevailing political systems wanes, one might expect this gap to widen, leading to the transition.

JOSEPH RAZ, THE CONCEPT OF A LEGAL SYSTEM: AN INTRODUCTION TO THE THEORY OF LEGAL SYSTEM (1970) (providing systematic effort to specify conditions for law).

59. Judgment of Jan. 20, 1992, Landgericht [LG] (Berlin), 13 JURISTEN ZETTUNo 691, 695 (1992) (F.R.G.).

60. See id. The Coun found not only that the border policy did not compon with the prevailing social understanding of law, but also that the prior understanding of law was consonant with that of the West.

61. See supra note 42.

62. See RAZ, supra note 12, at 214; see also Fuller. supra note 23.

63. See generally BoAventura de Sousa Santos, Toward a New Common Sense: Law. SCiEnce AND POLITICS IN THE PARADIGMATIC TRANSITION (1995) (articulating theory of law in light of dynamic law/society relation). 


\section{The Role of International Law}

Another mediating concept of the transitional rule of law is international law. International law posits institutions and processes that transcend domestic law and politics. In periods of political flux, international law offers an alternative construction of law that, despite substantial political change, is continuous and enduring. Local courts rely upon these international understandings. The potential of this understanding of international law gained force in the postwar period. ${ }^{64}$ In the contemporary moment, international law is frequently invoked as a way to bridge shifting understandings of legality. In the post-Communist cases discussed above, the controversy over the attempt to revive old political prosecutions was ultimately resolved by turning to concepts of international law. For example, in its review of a law proposing to reopen political cases relating to the 1956 uprising, the Constitutional Court of Hungary reasoned that reopening such cases was discontinuous with prior law. ${ }^{65}$ In a second round of judicial review, the Court upheld a new statute authorizing 1956 prosecutions based upon offenses constituting "war crimes" and "crimes against humanity" under international law. ${ }^{66}$ The rule of law required continuity. Such continuity was considered to exist in international legal norms, ${ }^{67}$ for such norms overrode domestic law. ${ }^{68}$ Throughout the

64. A jurisprudential debate arose, particularly in the United States, over whether postwar trials convened at Nuremberg and Tokyo were in keeping with the rule of law. International law served as a mediating concept to mitigate the dilemma of the rule of law raised by successor justice in transitional times, and to justify the legality of the Nuremberg Trials against concerns over retroactivity. See Hans Kelsen, The Rule Against Ex Post Facto Laws and the Prosecution of the Axis War Criminals, JUDOB ADVOCATE J., Fall-Winter 1945, at 8, 8-12, 46 (discussing nature of jurisdiction of Nuremberg Tribunal and other postwar trials); Bemard D. Meltzer, Comment, A Note on Some Aspects of the Nuremberg Debate, 14 U. CHI. L. REv. 455, 457 (1947) ("The strict and automatic application of the rule against retroactivity to an undeveloped legal system [such as international law] would, of course, have widened the gap between the developing moral sense of the community and its lagging legal institutions."). See generally Stanley L. Paulsen, Classical Legal Positivism at Nuremberg, 4 PHIL. \& PUB. AFP. 132 (1975) (arguing that Nuremberg Tribunal's rejection of Nazi defenses was justified by its rejection of classical legal positivism); Quincy Wright, Legal Positivism and the Nuremberg Judgment, 42 AM. J. INT'L L. 405 (1948) (arguing that criticism of Nuremberg Trials as applying ex post facto law is rooted in critics' positivistic theory of international law).

65. Such discontinuity, the Constitutional Court said, threatened the understanding of legality in the successor period; there was no principled way to break selectively with prior law. The "legitimacy of the different (political) systems during the past half-century is irrelevant ...; from the viewpoint of the constitutionality of laws it does not comprise a meaningful category." Constitutional Court of the Hungarian Republic Resolution No. 11/1992 (III.5) AB, translated in 1 J. CONST. L. E. \& CENT. EUR. 129, 136 (1994).

66. See Act on Procedures Conceming Certain Crimes Committed During the 1956 Revolution, Feb., 1993 (Hung.) (on file with Center for the Study of Constitutionalism in Eastern Europe, Univ. of Chicago).

67. Applicable international law included the postwar Geneva Convention Relative to the Protection of Civilian Persons in Time of War, Aug. 12, 1949, 6 U.S.T. 3516, 75 U.N.T.S. 287 [hereinafter Geneva Convention], and the Convention on the Non-Applicability of Statutory Limitations to War Crimes and Crimes Against Humanity, adopted and opened for signature Nov. 26, 1968, 754 U.N.T.S. 73 (entered into force Nov. 11, 1970).

68. See Resolution of the Hungarian Constitutional Court of Oct. 12, 1993 on the Justice Law (Case 53/1993) (on file with Center for the Study of Constitutionalism in Eastern Europe, Univ. of Chicago). Tho notion that international law took precedence over domestic law was by no means clear, as Hungary's 
region, international law would become the basis for punishment policies because these norms transcended the politicized law of the past regime. In another border guards case, the judgment holding actions unlawful explicitly rests on international law. ${ }^{69}$

In periods of political flux, international law offers a useful mediating concept. The framing of the rule-of-law dilemma easily shifts from the antinomies of positivism and natural law to those of national and international law. Grounded in positive law, but incorporating values of justice associated with natural law, international law mediates the rule-of-law dilemma. ${ }^{70}$ Moreover, in its normative circumscription of the most heinous abuses, international law offers a source of normative transcendence." Whereas international law preserves the ordinary understanding of the rule of law as settled law, it also enables transformation. In so doing, it mediates the transition. $^{72}$

\section{The Rule of Law as Antipolitics}

Above, I suggested that the defining feature of the rule of law in periods of political change is that it preserves some degree of continuity in legal forms, while it enables normative change. The previous politicized nature of law and adjudication partially justifies nonadherence during the transition. This understanding of the rule of law as antipolitics is a common theme throughout

Constitution was silent on the relative priorities of domestic and intemntional law. The Coun suggested it would interpret the Constitution guided by international norms, declaring thal "generally recognized rules

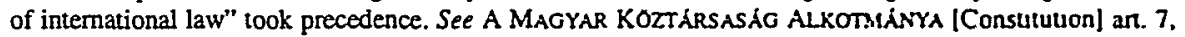
cl. 1 (Hung.) ("The legal system of the Republic of Hungary . . harmonises the intemal laws and statules of the country with the obligations assumed under intemational law."). The constitutions of other countries explicitly provide for such priority ranking. See, e.g., SYNTAGMA DES Hellados [Constitutuon] ar. 28, cl. 1 (Greece) (declaring that rules of intemational law shall prevail over contrary domesuc law).

69. See Border Guards Prosecution Case, Bundesgerichtshof [BGH] (F.R.G.), translased in 100 I.L.R. 366, 380-82 (1995) (relying on International Covenant on Civil and Political Rights, opened for signature Dec. 19, 1966, 999 U.N.T.S. 171 (entered into force Mar. 23, 1976), to hold that domestuc order infnnged human rights protected by intemational treaty); see also Krisztina Morvai, Retroactuve Justice Based on Intemational Law: A Recent Decision by the Hungarian Constitutonal Cour. E. EUR. CONST. REV.. Fall 1993/Winter 1994, at 33; Law on Genocide and Crimes Against Humanity Commuted in Albana During Communist Rule for Political, Ideological and Religious Motives, translated in HuMsas RIGHTS WATCH. HUMAN RIGHTS IN POST-COMMUNIST ALBANLA app. A (1996) (establishing basis for proseculung former Communists).

70. See Statute of the International Cour of Justice, Oct. 24, 1945, ant. 38(1). S9 Stat. 1031. Postive international law norms are defined in conventions, treaties, and customs. For an account of the posturast understanding, see OSCAR SCHACHTER, INTERNATIONAL LAW DN THEORY AND PRACTICE 35-36 (1991). The role of custom in the formation of intemational law is described in Michael Akehurst. Custom as a Source of Intemational Law, 47 BRIT. Y.B. INT'L L. 1 (1974-75).

For a related discussion regarding elements of natural and positivist law present in internaltonal law. see SHKLAR, supra note 55, at 126-28.

71. An illustration is the concept of crimes against humanity, suggestung conceptually opposite and yet related values, in the universalized normative response to persecutuon epitomizing absolute cvil. See J.M. Balkin, Nested Oppositions, 99 YALE L.J. 1669 (1990) (book review); see also infra Pan II.

72. International law principles surface in reconciling the threshold dilemma of law in penods of political transformation. See infra notes $119-22$ and accompanying text. 
the contemporary transitional controversies discussed above. The border guards trial was characterized as an "extreme case," justifying departure from ordinary rule-of-law considerations. ${ }^{73}$ The German Court elevated what was morally right over the political. Other cases in the region suggest similar judicial interpretations of the rule of law. Hungary's invalidation of the 1956 prosecutions law presented a limit on politicized anti-Communist policies. ${ }^{74}$ If under repressive rule the administration of justice was conducted purely as an exercise of political will, ${ }^{75}$ this understanding is most clearly disavowed when the successor regime adopts the overriding rule-of-law value that most clearly expresses a principled normative vision, independent of transitory politics.

The construction of the transitional rule of law as independent of politics shares certain affinities with the understanding of the rule of law applicable in ordinary times. Yet controversies over transitional justice in highly politicized contexts present hard cases for adherence to the rule of law. Despite radical political change, the rule of law is law not primarily motivated by politics. Transitional jurisprudence reveals a shining vision of the rule of law as antipolitics.

\section{The Transitional Judiciary}

In periods of political transformation, the problem of legality is distinct from the problem of the theory of law as it arises in established democracies in ordinary times. There is a working out of core questions about the legitimacy of the new regime, including the nature and role of the transitional judiciary. The choice of principles of adjudication implies a related question about where, as an institutional matter, the work of transformation should lie: judiciary or legislature? This is the question to which I now turn.

The transitional justice dilemma arises during periods of substantial political change. When a legal system is in flux, the challenge to ordinary understandings of the rule of law is surely at its greatest. This was less true of postwar transitions than of the more contemporary movements from Communist rule, periods of simultaneous economic, political, and legal transformation. In these periods, newly founded constitutional courts have

73. See Judgment of Jan. 20, 1992, Landgericht [LG] (Berlin), 13 JURISTEN ZerruNa 691, 693 (1992) (F.R.G.).

74. See supra note 65 . In evaluating a law that would have extended the time for prosecution of crimes committed under prior rule, the Czech Constitutional Court upheld it on the basis that it would serve the goal of undoing the past politicized punishment policy and administration of justice. The law would suspend the time limitations for 41 years (the time between February 25, 1948 and December 29, 1989) for acts not previously prosecuted or punished for "political reasons." See Decision on Act No. 198/1993 Sb, supra note 41.

75. For an account of the nature of such decisionmaking in illiberal political systems see the discussion of decisionism in CARL SCHMITT, POLMICAL THEOLOOY 53-66 (George Schwab trans., 1985). 
borne an institutional burden of establishing new understandings of the rule of law. ${ }^{76}$ It could be questioned whether continuity with the prior regime is a determination properly for the transitional judge, or a political question properly subject to broader public debate. When this question arose in the contemporary post-Communist transitions, the judiciary assumed the decisionmaking responsibility. This issue began as a political question in unified Germany, but in its consideration of the question of the validity of German Democratic Republic (GDR) law in the border guards cases, the Berlin court elided the political agreement of the two Germanys. ${ }^{n}$ In so doing, the Court demonstrated its independence from the legislature and its political agenda ${ }^{78}$ Similarly, when Hungary's Constitutional Cour overturned the 1956 prosecutions law, it sent a similar message of independence to the country's political branches. ${ }^{79}$ These decisions reveal a core understanding of rule of law forged by a transitional judiciary striving for independence from politics.

Political theorists often distinguish liberal from illiberal regimes by their constitutions; the role of transitional constitutionalism is discussed more extensively in Part III. Yet the central factor distinguishing liberal political systems seems to depend less on the specifics of any one institutional arrangement, and more on the degree to which there is a sense of meaningful enforcement and understanding of the rule of law. Although the Communistera constitutions enumerated rights, these were largely rights on paper that were rarely enforced. Therefore, after Communism, merely enacting new rights charters would not produce a sense of transformation in the rule of law. Responding to this distinctive legacy of injustice are the dozen constitutional courts that seek to enforce the new states' constitutions. ${ }^{80}$ This transformative role for the judiciary is a "critical" legal response that affirmatively signals a turn toward the constitutional systems of liberal democracies. ${ }^{81}$

76. For description of the beginnings of this development, see Herman Schwartz. The New East European Constitutional Courts, 13 MICH. J. INT"L L. 741 (1992). The burden of transformation to a ruleof-law system has to some extent devolved on the judiciary, chiefly the new constitutional courts See Rutı Teitel, Post-Communist Constirutionalism: A Transirional Perspecnve. 26 CowM HUM RTS L REV 167 (1994). For a wide-ranging collection of essays on East European constututional courts, sec CONSTITUTIONALISM IN EAST CENTRAL EURope (Irena Grudzirisika-Gross ed. 1994) A simular transformative response can be seen in other recent transitions, such as that in South Afnes. South Afnea's transitional Constitution creates its new constitutional Coun. See S. AFr. CONST. ch. VIl (1993)

77. The Unification Treaty contemplated continuity in former GDR criminal law, providing that East Germany's criminal code should be applied to criminal acts commiued before unfication. However, the Cour rejected the border guards' defenses grounded in GDR law See Judgment of Jan 20. 1992. Landgericht [LG] (Berlin), 13 JURISTEN ZETTUNG at 694.

78. However, the transformative response to the political was less necessary in unified Germany than elsewhere in the region because of the nature of the transiuons.

79. See Constitutional Cour of the Hungarian Republic Resoluuon No. $11 / 1992$ (III 5) AB, translated in 1 J. CONST. L. E. \& CENT. EUR. 129 (1994).

80. See Teitel, supra note 76 , at 169-76.

81. For discussion of comparable transformatuve constututuonal responses, see infra notes 197-99, 277-79, and accompanying text. 
The constitutional courts assist in the transformation to rule-of-law systems in a number of ways. First, the courts emerge out of systems of centralized state power; as new forums specially created in the transformation, their very establishment defines a break from past political arrangements. Second, access to constitutional courts through litigation enables a form of participation in the fledgling democracy. Over time, access to the courts could enable popular input into constitutional interpretation, developing a societal understanding of limited government and individual rights protection. Popular access to courts for individual rights enforcement is a potent symbol of a new governmental openness. ${ }^{82}$ Third, to the extent the constitutional courts have explicit mandates to engage in judicial review, they have become guardians of the new constitutional order. ${ }^{83}$ They are active in interpreting constitutional norms under prior constitutions, pursuant to general mandates to uphold the rule of law. ${ }^{84}$ The constitutional courts have the potential to delimit state power, and to redefine individual rights, thus creating a rights culture. Through transformative adjudication, the transitional judiciary deploys activist principles of judicial review toward normative change and a more liberal rule-of-law system.

Transformative adjudicatory practices raise a crucial question: Insofar as the transitional judiciary bears the burden of the transformation of the rule of law, to what extent are such practices compatible with the role of the judiciary in established democracies? In democracies in ordinary times, activist judicial decisionmaking is generally considered illegitimate. This is so largely for two reasons. First, retroactivity in judicial decisionmaking challenges the rule of law as settled law. ${ }^{85}$ Second, judicial originality is thought to interfere with democracy; unlike legislative decisionmaking, judicial decisionmaking lacks the legitimacy associated with democratic processes. ${ }^{86}$ To what extent are these objections relevant to adjudication in transitional times?

Our intuitions about who ought to make law depend upon implicit assumptions about democracy and democratic accountability that ought not be automatically applied to illiberal regimes, nor to regimes beginning to move away from such rule. In established democracies in ordinary times, our

82. See Ethan Klingsberg, Judicial Review and Hungary's Transition from Communism to Democracy: The Constitutional Court, the Continuity of Law, and the Redefinition of Property Rights, 1992 BYU L. REV. 41, 62 (discussing remarkable access implied by Hungary's permissive standing rules). While Hungary offers the broadest access, it is not alone in the region in contemplating participation in constitutional litigation by political actors.

83. In much of the region, broad jurisdictional rules allow abstract judicial review, and access to review by political actors, such as the president or minority factions of the legislature. See Teitel, supra note 76 , at $186-87$.

84. A good example is the Hungarian Constitutional Court's review of the 1956 prosecutions law. See Constitutional Court of the Hungarian Republic Resolution No. 11/1992 (III.5) AB, translated in $1 \mathrm{~J}$. CONST. L. E. \& CENT. EUR. 129 (1994).

85. See DWORKIN, TAKING RIGHTS SERIOUSLY, supra note 6 , at 84.

86. See id. at $84,138$. 
intuitions are that transformative lawmaking should occur by legislation rather than adjudication. The judiciary is constrained from creating law, for such lawmaking is considered a departure from the general predicate of democracy, majoritarian lawmaking. ${ }^{87}$ In transitional times, the problem of illegality is far more prevalent, indeed pervasive. Periods of political transformation are frequently accompanied by radical legal change. The most recent wave of political change correlating with economic transformation implied a major overhaul of preexisting law. The conventional concern of the absence of democratic accountability posed by judicial lawmaking seems less apt in periods of political flux. In such periods, the transitional legislature frequently is not freely elected and, further, lacks the experience and legitimacy of the legislature operating in ordinary times. ${ }^{88}$

A second reason why the judiciary is not generally seen as the proper lawmaking body is its lack of institutional competence and capacity. This concern was raised, for example, in the postwar debate over the rule of law. ${ }^{89}$ In the positivist position, the burden of legal transformation was thought properly to fall upon the legislature, while the natural law position assumed a transformative role for adjudication. Yet the postwar debate did not take account of the transitional context. As periods of political change are also periods of legal flux, controversies in such times are often characterized by a lack of relevant law. ${ }^{90}$ Moreover, controversies in such extraordinary periods often necessitate speedy considerations. While in ordinary times, making law in a case-by-case fashion may well appear too slow and too variable, in transitional times, judicial decisionmaking is often relatively faster than the legislative process, which may be slowed down by a compromised past or political inexperience. Moreover, in the context of political fux, the judiciary may well be comparatively more competent for nuanced, case-by-case, resolution of transitional controversies. ${ }^{91}$ Indeed, judicial decisionmaking allows for substantial change, and for what I have characterized as the ambivalent directionality of the law in such periods.

87. On the traditional paradigm of the judiciary, sce generally MARTR SHAPIRO. Courts: A Comparative and polmical analysis (1981). Cf. Mauro Cappelletti. The Judiclal Process in Comparative PERSPECTIVE 31-34 (1989) (observing tha judges necessarily "make law" by unterpreung it, but distinguishing this function from that of legislators, who act in procedurally distunct manner). For classic statements regarding the role of the judiciary in democracy, see generally ALEXswDER M. BiCKEL.

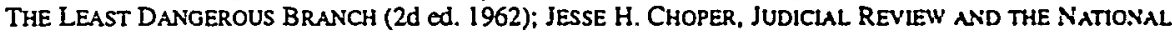
POLITICAI PROCESS (1980); and JOHN HART ELY, DEMOCRACY AND DISTRUST (1980).

88. During the initial political shif, transitional parliaments are generally vestiges of the pnor repressive period. See Andrew Arato, Dilemmas Arising from the Posser to Create Consurutions in Eastem Europe, 14 CARDOZO L. REV. 661, 674-75 (1993).

89. See supra notes $23-24$ and accompanying text.

90. For a discussion relating Russia's current plight to the absence of concentrated state power, see Stephen Holmes, Can Weak-State Liberalism Survive? (Spring 1997) (paper presented at Colloquium on Constitutional Theory, N.Y. University School of Law, on file with author).

91. See Teitel, supra note 76 , at 182-85. 
Finally, transformative adjudication is self-regarding. By changing adjudicatory principles and practices, institutions compromised by their decisionmaking under prior rule can transform themselves. In high-profile cases, a compromised judiciary can transform itself by drawing the line on past precedent and changing its principle of adjudication. This self-regarding institutional mechanism is particularly pertinent where the judiciary supported prior repressive rule. ${ }^{92}$ Where the judiciary is not the successor to a compromised institution, there are other beneficial legitimating implications of transformative adjudication.

Theories of adjudication associated with understandings of the rule of law in ordinary times are inapposite to transitional periods. Our ordinary intuitions about the nature and role of adjudication relate to presumptions about the relative competence and capacities of judiciaries and legislatures in ordinary times that simply do not hold in unstable periods. Indeed, the cases discussed above illuminate an extraordinary role for courts exercising principles of transformative adjudication. In periods of political change, the very concerns for legitimacy and democracy that ordinarily constrain activist adjudication may well support such adjudication as an alternative to more politicized uses of the law.

\section{E. The Transformative Adjudicative Domain}

I began this Part by positing that there is a special dilemma in adherence to the rule of law in periods of political change. The ordinary understanding of the rule of law as adherence to settled law is in tension with transformative understandings of the rule of law. I now consider what normative rule-of-law principles are associated with adjudication in periods of political change.

In these extraordinary periods, as discussed above, rule-of-law norms do not constitute universals. The tensions posed by adherence to the rule of law in these periods are reconciled through a number of mediating concepts. Legality in such periods is socially constructed; in some part, it is judge-made. Exploration of the precedents in such periods suggests that understandings of the rule of law are constructed within a transitional context. By cabining politicized uses of the law, this principle of legal decisionmaking defines an interim postrevolutionary space on the road to democracy.

Recognizing a domain of transformative adjudication during periods of political transition has significant implications for prevailing legal theory about the rule of law. First, recognition of such a domain throws into relief the extent to which prevailing legal theory has failed to take account of the

92. See, e.g., MOLLER, supra note 31, at 201-98 (discussing compromised judiciary in postwar Germany); cf., e.g., Osiel, supra note 52 (discussing aiternative strategies of judiciary under repressive Latin American rule). 
significance of varying normative understandings of the rule of law manifested in transitional, as opposed to ordinary, times. Further, the transitional rule of law poses an implicit critique of the dominant theories regarding the nature and role of law. In the dominant liberal position, lawmaking through adjudication is conceived as somehow neutral and autonomous from politics. ${ }^{93}$ These liberal understandings are challenged by accounting for circumstances associated with a role for transformative law, where the rule of law is defined in constructive relation to politics past.

The domain of transformative adjudication may pose a more serious challenge to critical theorizing of law. Critical legal theorizing has been criticized for going too far in collapsing law and politics. As such, this theoretical approach has lacked explanatory power for why, or in what circumstances, law has any distinctive claim on society. Although critical legal theorizing has laid claims to a diminished rule of law as a general matter," the above discussion suggests that this is most true in extraordinary political circumstances. The transitional rule of law clarifies a place and a role for hyperpoliticized adjudication. From the perspective of critical legal theory, the challenge posed by the transformative adjudicative domain discussed here is the challenge posed by the boundedness of law's political action. ${ }^{95}$ Recognition of this domain reveals how the jurisprudence of these periods shapes the transition. Normative understandings of the role of law vary, not unsurprisingly, with political circumstances. Within transitional democracies, therefore, there is a place and a role for bounded political judgment.

Beyond adjudicatory practices, normative change constructive of a new legality is also effected though other forms of law. Criminal sanctions, ordinarily limited to punishing individual wrongdoing, play a broader role during transitions in challenging the legitimacy of past rule. These legal responses sanction and delimit abuses of past state power. In the next Part, I turn to the uses of criminal justice in transformative periods.

\section{Criminal justice}

Transitional justice is commonly linked in the public imagination with criminal justice and the trials of ancien régimes. ${ }^{96}$ The enduring symbols of

93. This is a longstanding precept of the rule of law in liberal poliucal theory, running from Fnedrich Hayek to the present. See, e.g.. DWORKN, LAW'S EMPIRE, supra notc 6: FULLER, supra note 19; HAYEK, supra note 19; LIBERALISM AND THE GOOD, supra notc 6.

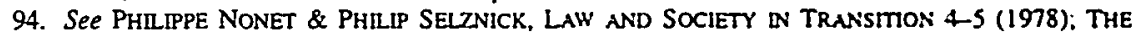
PolmTICS OF INFORMAL JUSTICE 267 (Richard L. Abel ed., 1982). David M. Trubek. Tuming Away from Law?, 82 MiCH. L. REV. 824, 825 (1984).

95. On critical legal theory, see supra note 7. For exploration of the idea of the rule of law from the perspectives of liberalism and critical legal theory, sec generaily ANDREW ALTMIAN. CRTICAL LEGAL STUDIES: A LIBERAL CRITIQUE (1990).

96. See infra notes $105-07$ and accompanying text. 
the English and French revolutions from monarchic to republican rule are the trials of Kings Charles I and Louis XVI. A half-century after the events, the monument to the Nazis' defeat in World War II remains the Nuremberg Trials. ${ }^{97}$ Greece's trials of its colonels represents the triumph of democracy over military rule in Central Europe. ${ }^{98}$ Argentina's junta trial marked the end of decades of repressive rule throughout Latin America. ${ }^{99}$

Successor trials dominate our understanding of justice in transitional periods. The harshest form of law has an impact of symbolic dimensions extending far beyond its incidence. Criminal justice is thought to play a foundational role in the political transition. The claim is that trials can create a new sense of legal order; that in the move to more liberal democracy, trials can serve as foundations.

The notion of trials as foundations for liberalizing political change derives from longstanding practices linking such legal responses to the postwar justification for state violence. ${ }^{100}$ In trials going back to the Middle Ages, the tyranny of monarchic regimes is captured in the unjust war. ${ }^{101}$ Law's role is to express the justice of the successor regime. Thus, attribution of criminal responsibility to prior political leadership for waging unlawful war, or other analogous acts of state, is the thread running through the ancient successor trials of the city-state tyrants described by Aristotle, the trials of Kings Charles I and Louis XVI, the Nuremberg Trials, and more recent successor trials. ${ }^{102}$

Contemporary political theorizing frequently justifies successor trials by relating criminal law enforcement to societal prospects for consolidating democracy. This version of the consequentialist argument is grounded in the rule of law. ${ }^{103}$ Successor trials are thought to advance transformation by drawing a line between regimes, through processes that simultaneously delegitimate the predecessor and legitimate the successor regimes. ${ }^{104}$ The trials of Kings Charles I and Louis XVI and the Nuremberg Trials have been characterized as foundational political acts: "Revolutionaries must settle with the old regime: that means they must find some ritual process through which

97. See infra text accompanying notes $111,113-21$.

98. See infra note 163.

99. See supra note 1; infra note $131,162$.

100. See Michael Walzer, JUST AND UNJUST WARS 289-90 (1977).

101. See JAMES TURNER JOHNSON, JUST WAR TRADITION AND THE RESTRAINT OF WAR 121-71 (1981); WALZER, supra note 100, at 22-25; Paul Ramsey, The Just War According to St. Augustine, in JUsT WAR THEORY 8-22 (Jean Bethke Elshtain ed., 1992); see also M. Campbell Smith, Introduction to IMMANUEl KANT, PERPETUAL PEACE 23-24 (M. Campbell Smith trans., Macmillan Co. 1903) (1795).

102. See infra notes $105-07,109-10$ and accompanying text.

103. Successor trials have been defended along these grounds: "[P]olitical trials may actually serve liberal ends, where they promote legalistic values in such a way as to contribute to constitutional politics and to a decent legal system." SHKLAR, supra note 55, at 145. Similarly, Otto Kirchheimer has written of the demand "for the construction of a permanent, unmistakable wall between the new beginnings and the old tyranny." KIRCHHEDER, supra note 1, at 308.

104. For an exploration of the various justifications for successor trials, see Ruti Teitel, How Are the New Democracies of the Southem Cone Dealing with the Legacy of Past Human Rights Abuses? (Council on Foreign Relations Discussion Paper) (May 17, 1990). 
the ideology it embodies ... can be publicly repudiated."10s Furthermore, "the [King's] trial was an act of destruction as well as the vindication of a new political doctrine; it represents the symbolic disenchantment of the realm as well as the establishment of a secular republic."106 The trials of kings expressed the principle of equality under the law, instantiating the transition from monarchy to republic.

Although successor trials are thought to play a distinctive foundational role, this Article contends that the function of such trials is less foundational than transitional. Trials offer a transitional mechanism for normative transformation to express public condemnation of aspects of the past, as well as public legitimation of the new rule of law. In particular, trials make it possible to isolate and delegitimate an individual past and wrongdoing. When societies move away from illiberal rule, the defining normative shift is in the status and treatment of the individual; construction of social understandings of individual responsibility chiefly occurs through the processes of criminal justice. Through the individuation of responsibility, trials offer a mechanism for recalling and disowning past wrongdoing, while confirming societal legal processes and institutions. ${ }^{107}$

Despite the claim that successor trials serve to establish more liberal regimes, periods of political upheaval challenge the use of the criminal law for normative purposes. Using trials to construct transition implies a profound dilemma created by the tension of mediating discontinuity and continuity in the law. Successor criminal trials are expected to lay the foundation of the transition by expressing disavowal of predecessor norms, yet for such trials to realize their normative potential, they must be prosecuted in keeping with the full procedural legality associated with working democracies in ordinary times. Otherwise, paradoxically, successor trials become vulnerable to challenge as political justice, where they may even threaten the construction of a fledgling liberal system. Thus, the attempt to use the criminal laws for normative change ultimately culminates in an extraordinary partial criminal sanction, in the use of criminal law primarily for its normative rather than punitive purposes. ${ }^{103}$

\section{A. The Dilemma of State Crimes but Individual Justice}

Using trials to construct individual responsibility for persecution in periods of political shifts raises a dilemma. There has long been an intuitive sense that

105. REGICIDE AND REVOLUTION: SPEECHES AT THE TRLAL OF LOUIS XVI, al 88 (Mifchael Walzer ed. \& Marian Rothstein trans., 1974).

106. Id.

107. For the classical arguments for punishment's role in expressing this liberal norm, sec GEORGE

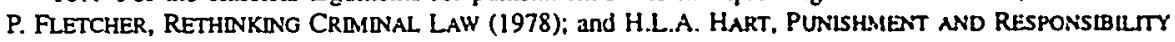
(1968).

108. The nature of this transitional sanction is more fully discussed infra Section II.D 
it is fair to ascribe responsibility to ancien régime leadership, linking up legal and political understandings of responsibility. During transitions, justice has generally been brought to bear against the top political leadership. ${ }^{109}$ Historically, responsibility is commonly understood in terms of military hierarchy and related principles of command responsibility. ${ }^{110}$ Predicating criminal responsibility upon the basis of military ideas of official responsibility might be sensible in a postwar context, for political change often follows war. Yet such shifts also occur in other ways; thus the military analogy does not easily guide the broader question of successor justice. In particular, the historical paradigm does not fully account for how to conceptualize individual responsibility for wrongdoing perpetrated under repressive rule, and the extent to which responsibility for past wrongdoing under illiberal regimes is fairly attributable to top political leadership. Equating criminal liability with political responsibility is foreign to penal concepts applicable in ordinary times; as a political basis for prosecution, it poses a challenge to the rule of law.

\section{B. The Nuremberg Paradigm Shift}

While the historical paradigm attributed responsibility to the leadership of the ancien régime, that standard changed with Nuremberg. The Nuremberg Trials are commonly considered the archetypal case of successor criminal justice in modern times. ${ }^{111}$ Nuremberg's significance leads back to the failure of trials after World War I, ${ }^{12}$ linked to the resurgence of German aggression

109. See REGICIDE AND REVOLUTION, supra note 105, at 4-7.

110. The military paradigm offers a way to conceptualize a regime's accountability. In the law of war, the principle of command responsibility affords a basis for attributing responsibility to superiors for wrongdoing. This is reinforced by the Nuremberg principles that lift the defense of immunity from heads of state. The extreme in status-based prosecutions after Nuremberg is illustrated in the Tokyo war crimes trials, where the principle of command responsibility was broadly enforced. See Judgment in the Tokyo War Crimes Trial, 1948, reprinted in part in CRIMEs OF WAR: A LEgAL, POLITICAL-DOCUMENTARY, AND PSYCHOLOGICAL INQUIRY INTO THE RESPONSIBILITY OF LEADERS, CITIZENS AND SOLDIERS POR CRIMINAL ACTS IN WARS 113 (Richard Falk et al. eds., 1971); see also In Re Yamashita, 327 U.S. 1, 13-18 (1946) (concluding that charges against commander of Japanese forces "adequately allege" violation of law of war).

In subsequent trials of high-ranking German army officers, the Yamashita standard was rejected, as the courts insisted on knowledge and individual participation, or acquiescence in the criminal acts or criminal neglect. See 11 TRLALS OF WAR CRIMNALS BEFORE THE NUREMBERo MiLITARY TRIBUNALS UNDER CONTROL COUNCIL. LAW No. 10, at 462 (U.S. v. von Leeb) (1948); id. at 1230 (U.S. v. List).

This version of the command responsibility principle would become enshrined in the international legal conventions governing war. Failure to take measures to avert particular harm is proscribed by the postwar Geneva Conventions. Explicitly rejecting Yamashita's should-have-known standard under Article 86 of the Conventions, knowledge triggers a duty to take "all feasible measures" to "prevent or repress the breach." Protocol Additional to the Geneva Conventions of 12 August 1949, and Relating to the Protection of Victims of International Armed Conflicts, Protocol I, June 8, 1977, 1125 U.N.T.S. 3, 43, 16 I.L.M. 1391, 1428-29.

111. See SHKLAR, supra note 55, at 145 .

112. Despite the Allies' attempt to obligate Germany to hold its war criminals accountable, few trials were held, and there were virtually no convictions. For an account of these failed national trials, see George Gordon Battle, The Trials Before the Leipsic Supreme Court of Germans Accused of War Crimes, 8 VA. L. REV. 1 (1921). 
and the advent of World War II. War-related guilt was said to prevent transition to democracy: The failure of accountability signified the failure of liberalization.

With Nuremberg, the paradigm of accountability shifts from national to international processes and from the collective to the individual. After Nuremberg, for the first time under international law, the response to persecution implied delimiting state power through the concept of individual responsibility. Prosecutions of past regime leaders effect this transformation. The trial sanctions the past regime's wrongdoing, moving beyond the state to the individual, and from political to legal judgment. ${ }^{113}$ In the Nuremberg Principles, ${ }^{114}$ for the first time, responsibility for atrocities under international law is attributed to the individual. ${ }^{115}$ Under traditional military rules, "due obedience" to orders was a defense, but under the Nuremberg Principles, even those acting under orders of their superiors could be held responsible. ${ }^{116}$ Furthermore, public officials could no longer avail themselves of a "head of state" defense based on sovereign immunity, but instead could be held criminally responsible. ${ }^{117}$ By eliminating the "act of state" and "superior orders" defenses, the Nuremberg Principles pierced the veil of diffused responsibility for wrongdoing perpetrated under illiberal regimes. With the challenge to traditional defenses to individual responsibility, potential individual criminal liability for state wrongdoing was dramatically expanded. These principles of criminal justice instantiate the core rule-of-law principle of equal applicability of the law. ${ }^{118}$

The strength of Nuremberg as precedent is not evident in international trials a half-century later. Nevertheless, Nuremberg's real legacy is that it spawned the dominant approach to state injustice. ${ }^{119}$ How justice was done

113. By this account of Nuremberg, I mean its precedentual value rather than the basts for the warume proceedings as reflected in the contemporary understanding of accountability for perseculton, and record of trials. See Symposium, 1945-1995 Critical Perspecrves on the Nuremberg Tnals and State Accountabilin, 12 N.Y.L. SCH. J. HUM. RTS. 453, 460-61 (1995).

114. The "Nuremberg Principles" formulated after the tnal at the request of the United Nations General Assembly are the distillation of the Nuremberg judgment and constitute a pivotal tumng point in the conceptualization of individual responsibility for state crime. See International Lan. Conmussion: Report on Principles of the Nuremberg Tribunal, U.N. GAOR, Sth Sess., Supp. No. 12, at 11. U.N. Doc. A1316 (1950).

115. See id. Principle I ("Any person who commits an act which constututes a crume under international law is responsible therefor and liable to punishment.").

116. See id. Principle IV "The fact that a person acted pursuant to order of his Govemment or of a superior does not relieve him from responsibility under international law, provided a moral choice was in fact possible to him.").

117. See id. Principle Ill ("The fact that a person who commulted an act which constlutes a crime under international law acted as Head of State or responsible Govemment official does not relieve hum from responsibility under international law.").

118. See supra text accompanying notes 93-95. Here we see affintues between transtuonal understandings of the rule of law and of criminal justucc.

119. The first such international criminal proceodings occurred a half-century later, convened in the Hague. See Statute of the Intemational Tribunal for the Former Yugoslavin. an. 5. annexed to Report of the Secretary-General Pursuant to Paragraph 2 of U.N. Securin Council Resolution 803. UN. GAOR. 
at Nuremberg has become virtually synonymous with successor justice. ${ }^{120}$ Nuremberg's transformation of our understanding of individual responsibility for grave state crimes implies a great potential for successor criminal justice. Yet it also leads to the following dilemma: The Nuremberg Principles imply a radical expansion of potential individual criminal liability, at both ends of the power hierarchy, with no clear stopping point. ${ }^{121}$ The Principles offer no guidance for deciding among all those potentially liable whom to bring to trial. The post-Nuremberg expansion in potential criminal liability raises a real dilemma for successor regimes deliberating over whom to bring to trial and for what offenses. After Nuremberg, what are the normative priorities in successor punishment policy? How should individual criminal responsibility be conceived in the attempt to use successor justice as the normative response to past evil? As a practical matter, the vast numbers of persons implicated in modern persecution, the scarcity of judicial resources in transitional societies, and the frequently high political costs of successor trials result in few trials. ${ }^{122}$ Given these constraints, viable successor criminal justice has been furthered through selective or exemplary trials. ${ }^{123}$ Yet this approach to successor criminal justice appears to revert back to the historical paradigm. ${ }^{124}$ Selective prosecutions targeting high officials threaten the liberal principle of individual

May 19, 1993, U.N. Doc. S/25704, reprinted in 32 I.L.M. 1159, 1193-97 [hereinafter Tribunal for the Former Yugoslavia].

120. International legal theory's perceived advantage in creating criminal accountability, combined with the real advances of the immediate postwar period, have made the international law vocabulary the dominant language of successor justice. The postwar period witnessed unprecedented successful multilateral cooperation in the International Military Tribunal at Nuremberg and the establishment of the United Nations, as well as the passage of numerous conventions and resolutions regarding international crimes. See Geneva Convention, supra note 67; Convention on the Prevention and Punishment of the Crime of Genocide, adopted by U.N. Gen. Assembly Dec. 9, 1948, 78 U.N.T.S. 277 (entered into force Jan. 12, 1951).

Early enthusiasm for international law's advances in normative development is now tempered by sober reflection on the relative inefficiency of international mechanisms in dealing with atrocitics. Despite repeated calls for an international criminal court, or even the creation of criminal jurisdiction in the International Court of Justice, to date, no such forum has been created. See generally James Crawford, The ILC Adopts a Statute for an International Criminal Court, 89 AM. J. INT'L L. 404 (1995) (discussing International Law Commission's draft statute to create international criminal court); Bernhard Gracfrath, Universal Criminal Jurisdiction and an International Criminal Court, 1 EUR. J. INT'L L. 67 (1990) (discussing United Nations's attempts to establish international criminal court).

121. Indeed, the absence of any judicial stopping point is evident at Nuremberg. Although the International Military Tribunal began its prosecutions with the major war criminals, nothing in the Charter limited the principle of individual responsibility to the Nazi regime's top echelon. To the contrary, the Charter explicitly contemplated that this was just the beginning and that there would be followup national trials. See Agreement for the Prosecution and Punishment of the Major War Criminals of the European Axis, Aug. 8, 1945, 82 U.N.T.S. 279.

122. A contemporary illustration is the genocide trials in Rwanda. See infra note 132.

123. For an argument for selective prosecutions, see Diane F. Orentlicher, Settling Accounts: The Duty to Prosecute Human Rights Violations of a Prior Regime, 100 YALE L.J. 2537 (1991).

124. For example, in a recent report, Helsinki Watch called upon the United Nations to establish a tribunal for the prosecution of war crimes "starting with those with the highest level of responsibllity for the most egregious crimes." HeLsINKI WATCH, WAR CRIMES IN BOSNIA-HERCEOOVINA 5 (1992). For discussion of the traditional successor justice paradigm, see supra notes 100-01 and accompanying text. 
responsibility; ${ }^{125}$ hence this is a paradoxical approach to transitional criminal responsibility. Insofar as the selective prosecutions approach elevates official status over traditional understandings of criminal liability, it challenges our sense that the level of fault should determine criminal responsibility. ${ }^{120}$ Nevertheless, our intuitions regarding the nature of criminal liability in ordinary times may not account well for transitional criminal justice. State crimes perpetrated in the context of illiberal rule commonly imply a special case of government wrongdoing, of violation of special duties, such as official responsibility for subordinates and the state's duty to protect its citizens. ${ }^{127}$ Exemplary prosecutions must walk a thin line if they are to express the intended democratic ideal. ${ }^{128}$

Contemporary successor trials have generally attempted to hold the political leadership accountable for the worst abuses of repressive rule. After World War II, the actions of the National Socialists and their collaborators prompted massive attempts at criminal accountability. ${ }^{129}$ In the second wave of political change in Southern Europe, Greek and Portuguese juntas were brought to trial. ${ }^{130}$ In the third wave of political change, there were national trials in Latin America, East Europe, and Africa. Argentina put its military on

125. As Yamashita shows, a broad status-based liability stundard holding commanders accountable for the acts of their subordinates can backfire. See supra note 110 . This issue became vital in the American debate over responsibility for Vietnam-related atrocities at My Lil. See United States y Callcy, 46 C.M.R. 1131 (1973), aff'd, 48 C.M.R. 19 (1973), rev'd. Callcy v. Callaway. 382 F Supp. 650 (M.D. Ga. 1974); see also CRIMES OF WAR, supra note 110, at 177-415 (collecting documents and essays regarding Vietnam. era war crimes); Gary Komarow, Individual Responsibility Under Imsemasıonal Lan. The Nuremburg Principles in Domestic Legal Systems, 29 INT'L \& COMP. L.Q. 21, 27-28 (1980) (duscussung Calley casee in this context). See generally TELFORD TAYLOR, NUREMBERG AND VIETNAM: AN AMERICAN TRAGEDY (1970) (exploring American political official responsibility for Vietnam-er atrocites in light of postwar precedents).

126. See generally HART, supra note 107, at 114-35 (exploring elements of mens rea giving nse to criminal responsibility).

127. For exploration of some of these questions, see generally Sanford Levinson, Responsibulity for Crimes of War, in WAR AND MORAL RESPONSBILITY 104 (Marshall Cohen el al. eds.. 1974): Dennis F. Thompson, Criminal Responsibility in Govermment, in NOMOS XXVII: CRMINAL JUSTICE 201 (J Roland Pennock \& John W. Chapman eds., 1985): and Richard Wasserstrom. The Responsibility of the Induvidual for War Crimes, in PHILOSOPHY, MORALTY, AND INTERNATIONAL AffalRs 47 (Virgina Held et al eds. 1974).

128. For an example in the Greek Tonure Trials, see O'DoNNeL \& SchsmTter, supra note 10, at 29-30, which discusses Greece's selective prosecutions.

129. Prosecutions of those implicated in World War II atrocitues sull comprose the largest body of precedent regarding criminal accountability. These national trials span close to five decades. encompassing common law, civil, and socialist legal systems. See supra notes 110-17 and accompanyıng text. See generally RANDOLPH L. BRAHAM, GENOCIDE AND RETRIBUTION (1983): INGE S NEUMAN. EUROPEAN WAR CRMES TrLALS (1951); ROCKERL, supra note 41: Symposium, Holocasest and Human Rights Law. The Fourth Intemational Conference, 12 B.C. THIRD WORLD L.J I (1992); Justice Mlenister. 5.570 Cases of Suspected Nazi Crimes Remain Open, WeEK IN GERMANY. May 3, 1996, al 7 (reporting Germany has prosecuted 106,178 persons since 1945; 6.494 convicled). For a full bibliographic lisung. see War CRIMES. WAR CRIMINALS, AND WAR CRMES TRIals (Norman E. Tulorow ed. 1986) (hereinafter War CrLies BIBLIOGRAPHY].

130. For a discussion of the Greek trials, see infra note 163 and accompanying text. For a discussion of the Portuguese transition, see Kenneth Maxwell, Regime Overthrow and the Prospects for Democranc Transition in Portugal, in TRANSTIONS FROM AUTHORTARLAN RULE: SOUTHERN EUROPE 109-37 (Guillermo O'Donnell et al. eds., 1986). 
trial. ${ }^{131}$ There were trials convened as well in Rwanda and South Africa, ${ }^{132}$ and recently in Asia. ${ }^{133}$ In isolated trials of Communists in East Europe, the pervasiveness of wrongdoing in totalitarian societies has generally defied principled attempts to secure criminal retribution. ${ }^{134}$

The difficulty of holding the prior political leadership accountable stems from other recurring questions of justice in periods of massive political change. ${ }^{135}$ In the successor trials following totalitarian rule, the attempt to apply a priority principle based on political status and to bring the leadership to justice for the worst crimes has meant successor prosecutions of offenses perpetrated either at the very beginning of Communist rule or during the regime's last gasps. Returning to offenses committed in the course of the Communist takeover means going back half a century. Bringing trials after such a lengthy passage of time incurs grave jurisdictional problems necessitating tampering with prevailing law. ${ }^{136}$ Such irregularities undermine the legality of the trials, and risk a message of political justice. ${ }^{137}$ Thus attempts to prosecute past wrongdoing have tended to focus on the violence

131. See David Pion-Berlin, To Prosecute or to Pardon? Human Rights Decisions in the Latin American Southern Cone, 16 HuM. RTS. Q. 105, 105-30 (1994).

132. See Payam Akhavan, The International Criminal Tribunal for Rwanda: The Politics and Pragmatics of Punis/ment, 90 AM. J. INT'L L. 501 (1996); Robyn Green, South African Apartheid Assassin Jailed for Life, REuTERS, Oct. 30, 1996, available in LEXIS, Nexis Library, Reuters File.

133. See The Mighty Fall in South Korea, ECONOMisT (London), Aug. 31, 1996, at 31, 31 (discussing treason charges against former Presidents for putting down Kwangju uprising); Tim Shorrock, Ex-Leaders Go on Trial in Seoul, J. CoMM., Feb. 27, 1996, at 1A.

134. For a journalistic account of the response in the region, see TINA ROSENBERO, THB HAUNTED LAND (1996). By far, the majority of the trials have been in unified Germany. In Germany, there have been trials at all levels, relating to the border shootings, as well as other Communist-era wrongdoing. More recently, in the post-Communist transitions, there have been scattered trials of the top leadership in Romania and Bulgaria, and trials of high- and mid-level party officials, in the Czech Republic. See infra note 138. Following political regime changes in the Balkans and in Rwanda, there have been domestic and international war crimes trials. See supra note 132; infra notes 143, 150, 155.

135. For a discussion of these dilemmas in adjudications of the rule of law in transformative periods, see supra Sections I.A.-B.

136. In Hungary, for example, a 30-year limitations law blocked trials of those who had used violence to put down the 1956 uprising. The attempt to lift the law after the fact was deemed unconstitutionally ex post facto, for all except the most serious crimes. See supra notes $42-45,65-69$, and accompanying text. For related discussion see supra notes $100-08$ and accompanying text. Similarly, in Poland, the statute of limitations was lifted in 1991 on crimes committed between 1946 and 1952, to allow the initiation of new criminal prosecutions. See Patricia Koza, Former Security Officers Go on Trial for Torturing Prisoners, UPI, Oct. 13, 1993, available in LEXIS, Nexis Library, UPI File. Similar tampering with the prior limitations law occurred in the Czech Republic, and was even sustained by its Constitutional Court. See Decision on Act No. 198/1993 Sb., supra note 41.

For discussion of the rule of law issues raised by such irregularities, see Schulhofer et al., supra note 38 , at 17 .

137. Whether under socialist or continental law, criminal liability is generally circumscribed on the basis of passage of time. Perhaps the extreme case of the attempt to nevertheless accommodate the criminal response after totalitarian repression was Germany's prosecution of its former East German Stasi security police chief, Erich Mielke. The attempt to bring this senior official to justice led all the way back to 1931 , involving 61 -year-old offenses relating to murder committed in the last days of the Weimar regime. Prosecuting Mielke for offenses committed under the predecessor regime hardly related to the abuses perpetrated under Communist leadership. Mielke's case epitomizes the difficulty of responding to repression within ordinary understandings of criminal justice. See Erich Mielke Sentenced to Six Years for 1931 Murders, Faces Other Charges, WEEK IN GERMANY, Oct. 29, 1993, at 2. 
attending last-ditch efforts to sustain Communist rule. ${ }^{138}$ These attempts at securing individual accountability seem strangely beside the point. Prosecuting offenses committed in the predecessor regime's last gasps misses the nature of totalitarian rule, and thus cannot express a normative response to its distinctive form of repression.

Contemporary trials hold the leadership accountable on the charge of "bad rule." Bad rule after the Soviet collapse has generally meant economic crimes. ${ }^{139}$ In the recent transformations from command economies to free market systems, economic crimes prosecutions delegitimate the predecessor and legitimate the successor regimes. ${ }^{1+0}$ To the extent past party practices could be shown to be corrupt and unlawful, the effort was to put Communism outside the bounds of legitimate political choice. Just as the trials of the eighteenth-century transitions from monarchic rule were used to attack the institution of kingship, so too in the twentieth century, transitional successor trials are used to delegitimate Communist rule.

This prosecution policy raises rule-of-law problems endemic to successor justice. Successor trials commonly raise the problem of retroactivity, because

138. In the most notorious of such trials, in Romanta, andes to Nicolar Ceauseseu were convicted for their roles in the attempted suppression of the 1989 anti-Communist upnsing. See Adrian Dascalu. Romanta Jails Eight for 1989 Timisoara Uprising Massacre. REUTERs. Dec. 9. 1991. atalable in LEXIS. Nex1s Library, Reuters File. In the Czoch Republic, charges were brought aganst several high-level former Communist leaders for ordering the brutal repression of demonstrations in 1988 and 1989 Mhroslav Stepan. the former head of the Prague Communist Pary, was uned first and convicted in 1990. See Prague's ExParty Boss Guilty of Abuse of Power, CHI. TRIB., July 10, 1990. \$1, at 4 . The intenor munisters-Frantisek Kincl, Alojz Lorenc, and Karel Vykypel-were convicted in October of 1992 for theis parts See Caecis Allow Prosecution of Communist Crimes, ReUTERS, July 10, 1993, avalable in LEXIS. Nexis Library. Reuters File. In Russia, one of the few criminal proceedings iniusted was against the perpetrators of the August 1991 putsch. See Howard Wit, Russians Whitewash Blane for 1991 Coup. CH1. TkiB., Aug. 12, $1994, \S 1$, at 1 .

139. Economic crimes prosecutions center on the theft of "communal propeny" even though such offenses no longer exist after the fall of Communism. Prosecutıons against the former leadershup have been initiated for all sorts of economic crimes. Bulgaria's effor has been the most ambutous, with embezzlement charges brought against the country's former longtime ruler. See Ousfed Bulgarian Gets 7.Year Term for Embezzlement, N.Y. TIMES, Sept. 5, 1992, at A2; see also Bulgarian Fonner Prome Minister Sentenced ro Ten Years, REUTERS, Nov. 3, 1992, available in LEXIS, Nexis Library, Reuters File In the tnal of another Communist head of state. Albania's former President Ramiz Ala was prosecuted for abuse of power and embezzlement for misappropriating public funds. See Last Communist Prestdens Jaled for Nine Years. AGENCE FRANCE PRESSE, July 2, 1994, available in LEXIS. Nexis Library. Cumus Fule In Germany. the head of East Germany's labor federation was convicted of "fraud against sociahst property " See Marc Fisher, Former East German Labor Boss Convicted of Fraud, Released, W ASH. POST, June 7, 1991. Al Al 8 In the Czech Republic, former Communist leaders were subject to criminal investugatuons for tax evaston See Czech Republic: Slovakia Asked about Conmunis's Tax Exempiron. ReUtrers, Jan. 30, 1995, avalable in LEXIS, Nexis Library, Reuters File.

140. Perhaps the best example is the Moscow inal of its Communist Party, ansing after an altempt to ban the Party. See On Suspending the Activity of the RSFSR Communist Party. Vedomost Fed. Sobr RF., 1991, No. 35, item 1149, tanslated in CURRENT Dig. SOviet Press. Ot 2. 1991. at 11. Official Kremlin International New's Broadcast, July 6, 1992, aralable in LEXIS. News Library. Sounws File. David Remnick, The Trial of the Old Regime. NEw YORKER. Nov 30. 1992. at 104 Although there are precedents for criminalizing organizations such as at Nuremberg. there the organizalional convictions were to serve as predicates for subsequent charges of individuals See TELFORD TAYLOR, THE ANATOMY OF THE NUREMBERG TRIALS 35-36 (1992). In its unconventional use of the cnminal process to try a political party. the Moscow trial tests the boundaries of the criminal law for transitional normaluve purposes 
normative change frequently implies prosecutions of new offenses enacted after the fact. When prosecutions fail to guarantee prospectivity, as when they imply predecessor offenses that have lost force, they challenge ordinary understandings of the rule of law. When the elements of political authority and the gravity of offense become disconnected, ${ }^{141}$ the purpose laid bare is the political one of eliminating the opposition. This policy risks being perceived as political justice, threatening the normative purposes of prosecution.

An alternative line of successor trials focuses criminal accountability not on those most politically responsible, but instead upon perpetrators of the worst offenses. This offense-based approach leads all the way down to the lowest rung of the totalitarian state, to the police and guards who personally committed brutalities. Greece's 1975 "torturers' trials" represent an illustration of offense-based trials. ${ }^{142}$ A more contemporary example is the Balkans trials. ${ }^{143}$ As with the trials of the political leadership, offense-driven trials do not fit easily within the criminal justice framework applicable to ordinary times. Although the trials comprehend the most serious offenses of prior rule, the gravamen of these prosecutions, torture or war crimes, are not generally considered offenses under prevailing law. When offense-based successor trials imply tampering with prevailing procedure, these irregularities can undermine the rule of law. Moreover, insofar as such trials seem to exonerate leaders, they appear to scapegoat those brought to justice. Such prosecutions raise the perception of politicization, and challenge criminal justice's ability to construct the transition.

\section{The Crime Against Humanity and Contemporary Tyranny}

The normative potential of transitional criminal justice is most clear in the response to the most extreme form of persecution. Prosecution of the crime against humanity exemplifies a transitional measure of a critical transformative form. ${ }^{144}$ By definition, the crime against humanity is the core offense of modern repressive rule, the paradigmatic offense against mankind. The crime against humanity comprises grave offenses, such as murder, deportation, and torture-long considered crimes when committed in wartime against civilians-as well as persecution based on political, racial, and religious grounds. ${ }^{145}$ Crimes against humanity are offenses that transcend national

141. An example would be the post-Communist economic crimes trials, where the prior leadership is being held accountable, but not for the most grave crimes of prior rule.

142. See supra note 128.

143. See The International Criminal Tribunal for the Former Yugoslavia Indictments Against Meakic and Others and Tadic and Others, 34 I.L.M. 1011, 1028-44 (1995).

144. For other illustrations, see supra notes 33-37, 51-55, 104-08, and accompanying text; infra texi accompanying notes $159,172,198$.

145. See Charter of the International Military Tribunal, Aug. 8, 1945, art. 6(c), 82 U.N.T.S. 279. 
boundaries and are considered to violate the laws of all nations. ${ }^{1+6}$

This jurisprudence evinces the clear delimiting of state power on the basis of individual rights norms. As the crime against humanity is often prosecuted outside the affected territory, in the absence of regime change, it is perhaps the purest illustration of the potential of law to effect normative transition and to offer a way to mediate the dilemma of successor justice. The concept is exemplified whenever states respond to atrocities in ways that transcend national borders. Indeed, the very response to the crime against humanity instantiates its core value of transcendent justice. ${ }^{147}$

The crime against humanity is an extraordinary criminal offense in several respects. It is exempt from traditional jurisdictional principles limiting the prosecution of ordinary crimes, such as territoriality and the passage of time. ${ }^{148}$ If, under the traditional jurisdictional principle of territoriality, where

146. At Nuremberg, prosecution was limited to those crimes against humanity also in some way related to the war. Though formally an independent charge, the crime against humanity was assimilated into other war crimes offenses, including violating the boundaries of permissible war. For an count. see TAYLOR, supra note 140, at 8-20. See also EUGENE DAVIDSON. THE TRLALS OF THE Gerbavis 1-38 (1966).

147. Through its international prosecutions, Nuremberg epitomized the central concept of the crame against humanity, but the concept precedes its codification al Nuremberg. Such intematuonal remonstrances occurred, for example, in response to Greco-Turkish warfare in 1827. See generally WAR CRLMES BBLLOGRAPHY, supra note 129, at 114-19; Egon Schwelb, Crimes Agaunst Humaniry. 23 BRIT YB INT'L L. 178 (tracing development of concept of crimes against humanity since Hague Convenuon of 1907) Similarly, in the early 1900 s, there were international remonstrances "in the name of humanity" against persecution in Romania and Russia. Regarding the World War I period, there were intemational responses to Turkish war crimes. See JaMes F. Willis, Prologue to Nurgaberg: The Polmics aNd Diplomacy OF PUNISHING WAR CRMMNALS OF THE FIRST WORLD WAR 157 (1982) (referring to 1919 characterizallon of Armenian massacres as offending "'what might be called the law of humanity or the moral law"') (quoting 1919 remark of Greek Foreign Minister Nicolas Politis)). Following World War I, a commıssion convened regarding the methods used in the waging of the war and declared that these practices violated the "established laws and customs of war and the elementary laws of humanuly" and were accordingly

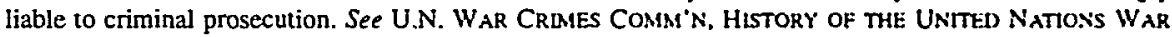
CRIMES COMMISSION AND THE DEVElopMeNT OF THE LAWS OF WAR 36 (1948): Contusston on the Responsibility of the Authors of the War and on Enforcement of Penalties. Mar. 29, 1919, reprinted in 14 AM. J. INT'L L. 95 (1920). The 1917 offenses were similar to those later descrnbed after World War It instruments: murder, torture, and racial persecution of minontues by their own govemments At the ume of the drafting of the London Charter and Control Council Liw No. 10, the UN War Cnmes Commission defined "crimes against humanity" as "systematic mass action".

Only crimes which either by their magnitude and savagery or by therr large number or by the fact that a similar pattern is applied at different tumes and places. endangered the intemational community or shocked the conscience of mankind, warranted interiention by stales other than that on whose territory the crimes have been commitled, or whose subjects have become their victims.

See U.N. WAR CRIMES COMM'N, supra, at 179.

148. See International Law Commission, supra note 114. Princuple II The fact that intemal law does not impose a penalty for an act that constitutes a crime under international law does not relieve the person who committed the act from responsibility under intemattonal law. See UN GAOR. Sth Sess. Supp No 12, U.N. Doc. A/1316 (1950), reprinted in W. MCHAEl Reisman \& Chris T ANTaNiou. THe Laws of WAR 335 (1994). See generally. Geneva Convention Relative to the Protection of Civilaan Persons in Time of War, Aug. 12, 1949, 6 U.S.T. 3516, 75 U.N.T.S. 287: Protocol Additional to the Geneva Conventions of 12 August 1949 and Relating to the Protection of Victims of International Armed Conflicts (Protocol 1), June 8, 1977, 1125 U.N.T.S. 609; United Nations Convention on Prohibitions or Restnctions un the Use of Cerain Conventional Weapons Which May Be Deemed to Be Excessively Injunous or to Have Indiscriminate Effects, Oct. 10, 1980, U.N. Doc. A/CONF/95/15, reprinted in 19 I L.M 1523 (1980) For 
the crime occurs is considered the place of the wronged community, every state could consider itself wronged by a crime against humanity, and thus every state is free to bring perpetrators to trial..$^{149}$ The central idea of the crime as an offense against all humanity is inextricably connected to the jurisdictional principle of universality and prosecutability by all nations. ${ }^{130}$ Similarly, such prosecutions are unconstrained by the ordinary parameters of time. While ordinarily criminal offenses must be written into domestic penal law to avoid violating basic principles against retroactivity, ${ }^{151}$ the crime against humanity is considered an offense "among civilized nations," and it is therefore punishable with or without legislation. ${ }^{152}$ Thus, between the Nazi and Communist reigns of terror and their successor prosecutions, there are gaps of close to half a century, ${ }^{153}$ colliding with our ordinary intuitions about criminal justice delayed. ${ }^{154}$ In the crime against humanity, distinguished by absence of ordinary jurisdictional limits, the potential of the criminal law transcends political boundaries and the need for regime change.

Over the years, the understanding of the crime against humanity has forged the definition of modern persecution. At first, the crime was conceptualized on an objective basis, as an offense defined in terms of classes of victims. Thus,

a comprehensive analysis of the contemporary status of related humanitarian law, see THEODOR MERON, HUMAN RIGHTS AND HUMANITARIAN NORMS AS CUSTOMARY LAW 10-25 (1989), which argues for convergence in the normative definition of rights violations.

149. Similar justifications provide the basis for the seemingly anomalous prosecutions in Canada, England, Scotland, and Australia following World War II. See Symposium, Prosecuting World War II Persecutors: Efforts at an Era's End, 12 B.C. THIRD WORLD L.J. 199, 199 (1992).

150. Thus, in the Eiclmann case, the jurisdictional principle of universality is considered inexiricably bound up with the nature of the crime against humanity. Adolf Eichmann's abduction from Argentina and his prosecution in Israel for crimes committed in Europe during the war epitomizes the principle of universality relating to jurisdiction for crimes against humanity. Because of the distinctive nature of the crime against humanity, Eichmann's trial was considered to violate neither retroactivity nor territoriality principles. See Attorney Gen. of Israel v. Eichmann, 36 I.L.R. 5 (D.C. Jm. 1961), aff'd, 36 I.L.R. 277 (S. Ct. Isr. 1962).

Contemporary crimes against humanity trials also rely upon similar understanding of universality. See Prosecutor v. Tadic, Case No. IT-94-1-AR72, Appeal on Jurisdiction (Appeals Chamber, Int'l Crim. Trib. Former Yugo., Oct. 2, 1995), reprinted in 35 I.L.M. 32 (1996).

151. There is an understanding ratified in most legal systems by laws establishing time limits, even for the most serious crimes. Regarding the crime against humanity and imprescriptibility, see Pierre Mertens, L'Imprescriptibilité des crimes de guerre et des crimes contre l'humanite, 51 REVUE DE DROIT PÉNAL ET DE CRIMINOLOGIE 204 (1970).

152. This special exemption of crimes against humanity from the ban on retroactive legislation, recognized at Nuremberg, has now become ratified as part of the European Convention on Human Rights: "This ... shall not prejudice the trial and punishment of any person for any act or omission which, at the time it was committed, was criminal according to the general principles of law recognised by civilised nations." European Convention for the Protection of Human Rights and Fundamental Freedoms, Nov. 4, 1950, art. 10, 213 U.N.T.S. 222, 230.

153. See Fédération Nationale des Déportés et Internés Résistants et Patriotes v. Barbie, 78 I.L.R. 125 (Fr., Cass. crim., Dec. 20, 1985).

154. More than a half-century after the events, World War Il-related trials are taking place not only throughout Europe, but also in Canada and Australia. On the question of the passage of time and legal responses, see, for example, DAVID CESARANI, JUSTICE DELAYED (1992), which describes the British campaign to find Nazi war criminals; DAVID MATAS, JUSTICE DELAYED: NAZI WAR CRimINALS IN CANADA (1987); and Symposium, supra note 149, passim. On the delay in the United States, sce AlLAN A. RYan, JR., Quiet NeIGHBors: Prosecuting Nazi WaR CRIMINALS IN AMERICA (1984). 
at Nuremberg, the crime against humanity was defined by the protected status of civilians during wartime. Over time, the crime against humanity extended beyond attacks by states against foreign enemies to the abuses perpetrated against even their own civilians during peacetime. The contemporary conceptualization of the crime against humanity is toward a subjective, highly normative understanding, protecting against racial, ethnic, political, or religious persecution. ${ }^{155}$ The significance of the offense has become generalized, with the potential for comprehending persecution on a seemingly universal basis. ${ }^{156}$

The crime against humanity criminalizes the ultimate political offense: political persecution, the offense of enemy creation. Although the crime against humanity is not explicitly predicated on state involvement, persecution constitutes a crime of ideology of such magnitude that even where not overtly state-promoted, it is considered as having been committed against a backdrop of government policy. ${ }^{157}$ The crime against humanity mediates individual and collective responsibility in the transition. State implication in political persecution epitomizes the contemporary conception of tyranny. Equality violations are nowhere more pronounced than where the state is the perpetrator and citizens are persecuted on a racial, ethnic, political, or religious basis.

155. In the 1987 prosecution of Klaus Barbie, the Nazs chief in occupied Lyon, for ordenng deportations to death camps, the critical issue was whether armed members of the resistance could nevertheless be protected under the rubric of the "crime against humanity:" For purposes of the cnme against humanity, the French High Court held that the relevant question was not the vicums' stalus, t.e. whether they were civilians or resistance, but whether the accused had acted with the requisite intent. What distinguished the crime against humanity was the purpose of persecution. See Barbie, 78 I.L R. at 139-40

The jurisprudence of the first international war crimes tribunals since the postwar penod. conceming violations in the former Yugoslavia and Rwanda, goes well beyond Nuremberg The various acts constituting crimes against humanity are: murder, extermination. ensluvement, deponation, impnsonment. torture, rape, persecution on political, racial, and religious grounds, and other inhumane acts See Trabunal for the Former Yugoslavia, supra note 119, at 1173. The understanding of the Commission of Expents was that the International Tribunal had jurisdiction over crimes against humanity. whether the conflict was "international" or "internal." As a matter of internatuonal customary law, the Commission of Experts considered that, no matter the nature of the conflict, universal junsdiction existed for cnmes agatnst humanity and genocide. See Final Report of the Commission of Experts Established Pursuant to Securnty Council Resolution 780, U.N. Doc. S/1994/674, al 13 (1992): see also Tadic. 35 I L . II at $48-73$ Further. the Tribunal's jurisdiction extends to crimes not commutted by agents of the stalc, so long as committed "under color" of the state. Article 2 on the competence of the Intemalional Tnbunal provides "The International Tribunal shall have the power to prosecute persons commutung or ordenng to be commited grave breaches of the Geneva Conventions of 12 August 1949," and then goes on to list specific offenses See Tribunal for the Former Yugoslavia, supra note 119 , al 1171

156. For an example of such legislation, consider the French cromes aganst humanuty law which incorporated the Nuremberg Charer, showing the sense in which the offense of erimes aganst humanity has become universalized. C. PÉN. Ar. 213-5 (Fr.).

157. In the Barbie opinion, France's High Coun defined persecution as commutted in a systematuc manner in the name of a "[s]tate practising a policy of ideological supremacy" Barbue, 78 IL R. at 128

This feature of the offense has jurisdictional consequences. As a practical matuer. implicalion of the state in the crime against humanity affects even the possibility of investigatuon. because of the likelihood of state coverup and other obstruction of justice, and, as such, justifies lifung the ordinary space and ume barriers to prosecution. This could be understood as analogous in the ordinary cruminal law to the justification for lifting of time limits to offenses like embezzlement and conspiracy, when these crimes implicate public of ficials. 
When criminal justice denounces these crimes, such prosecutions have a systemic impact transcending the implicated individual. ${ }^{158}$ To society, such trials express the normative value of equality under the law, a threshold value in the transformation to liberal democratic systems.

The normative implications of the legal response to tyranny transcend periods of political change. The transitional element of the crime against humanity becomes generalized. Even after the passage of time, these criminal sanctions can be used to reinvent the differences between liberal and illiberal regimes. For the late twentieth century, persecution for reasons of politics, race, ethnicity, and religion is incontrovertibly the paradigm of contemporary tyranny. ${ }^{159}$ In the crime against humanity jurisprudence, the strongest sanction in law is invoked to condemn past state evil. Where past systems of persecution were perpetrated under law, prosecution of persecution is an undoing that sends a message about a new legality.

\section{The Transitional Criminal Sanction}

The paradigm shift in notions of justice and fairness relating to application of criminal justice in periods of political change raises numerous recurring dilemmas discussed above. In the ordinary understanding of criminal justice, identifying and establishing wrongdoing and penalties are generally conceived

158. Debates over whether to prosecute throw into relief the distinctive gravity of the crime against humanity. Lifting time limitations has been justified as an exception for "atrocious" crimes. See, e.g., Question of Punishment of War Criminals and of Persons Who Have Commitred Crimes Against Humanity: Question of the Non-Applicability of Statutory Limitation to War Crimes and Crimes Against Humanity, U.N. Economic and Social Council, Commission on Human Rights, 22d Sess., Agenda Item 4, at 84, U.N. Doc. E/CN.4/906 (1996). In the debates over whether to extend the statutes of limitations for World War II-related murder, extensions were justified under a retributive rationale on the basis of the crime's heinousness. On the international level, the dilemma was resolved by the enactment of the United Nations Convention on the Non-Applicability of Statutory Limitations to War Crimes and Crimes against Humanity. See Convention on the Non-Applicability of Statutory Limitations to War Crimes and Crimes Against Humanity, Nov. 26, 1968, 754 U.N.T.S. 73. After a heated debate in 1965, when, according to prevailing penal law, 20-year limits on war-related charges would have set in, the West German Parliament attempted to put a stop to the trials; ultimately, the resolution was to limit most of the World War II-related offenses, but to lift the time limits applicable to offenses comprising crimes against humanity (defined as "basc motive" murder). See Robert Monson, The West German Statute of Limitations on Murder: A Political, Legal and Historical Exposition, 30 AM. J. COMP. L. 605, 610-11 (1982). For an account of Germany's arguments for lifting the statute of limitations on World War II-related murder, see Martin Clausnitzer, The Statute of Limitations for Murder in the Federal Republic of Germany, 29 INT'L \& CoMP. L.Q. 473, 478 (1980). Amnesties were rejected on the grounds they would offend the dignity of tyranny's victims. Justifications for criminal accountability on the basis of the victims' dignity also appear in the more recent transitions. For discussion of the punishment/impunity debate, see Jaime Malamud-Goti, Punis/ment and a Rights-Based Democracy, CRIM. JusT. ETHICs, Summer-Fall 1991, at 3. Regarding the role of victims in the pursuit of punishment as a general matter, see Jeffrie G. Murphy, Getting Even: The Role of the Victim, in CRIME, CulPABILITY, AND REMEDY 209 (Ellen Frankel Paul et al. eds., 1990).

159. Thus, in American constitutional jurisprudence, for example, state-sponsored racial, ethnic, and religious discrimination is considered to be a grave abrogation of equality, and is accorded the highest constitutional protection. Racially motivated crimes can revive past state-sponsored racial persecution even where privately sponsored, and can have profound significance. The persistence and understanding of the nature and role of successor criminal justice may well help to explain the special significance of contemporary domestic trials involving racial crimes. 
as a unitary practice, but in the criminal sanction's transitional form these elements become detached from one another. The partial criminal process, emphasizing prosecution over punishment, distinguishes the transitional criminal sanction.

The transitional criminal sanction prosecutes past regime wrongs but does not necessarily culminate in individual culpability and punishment. The emergence of this transitional criminal sanction in periods of political change is illustrated throughout history, for example in the post-World War I trials, ${ }^{160}$ the World War II cases, ${ }^{161}$ the postmilitary trials of Southern Europe, as well as contemporary successor criminal justice in Latin America ${ }^{162}$ and Africa. In the wave of political change in Central Europe that followed the fall of the Berlin Wall, a similar sequence unfolded. ${ }^{163}$ Throughout the region, there has been a general movement toward the limitation of criminal proceedings and punishment. ${ }^{164}$ As in the postwar period, successor justice after totalitarian rule has revealed a de facto limiting of the criminal sanction.

The emergence of the transitional criminal sanction in periods of political flux presents an alternative to the complete waiver of punishment. ${ }^{105}$ In

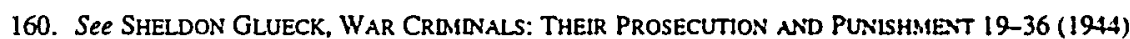
(providing account of history of action taken against German war criminals under Treaty of Versalles). see also Willis, supra note 147, at 116-39, 174-76 (exploring post-World War I efforts to punish war criminals as precedents for Nuremberg).

161. Many convicted in the Control Council Law No. 10 trials by occupanon authonues were lighuly punished under a clemency program supervised by U.S. High Commissioner John McCloy. See FRANK M. Buscher, THE U.S. WAR CRIMEs TRLal PROGRaM IN Germany, 1946-1955, at 62-64 (1989).

162. Shonty after the 1980 s Argentine junta trials there were limits on the follow-up unals and pardons. Ultimately, presidential pardons would extend to everyone convicted of atrociues, even highranking junta leaders. See AMERICAS WaTCH. TRUTH AND PARTLAL JUSTICE IN ARGENTLNA. AN UPDATE 45-52, 65-70 (1991); Pion-Berlin, supra note 131.

163. Greece's trials of its military police culminated in suspended or commutable sentences See AMNESTY INTERNATIONAL, TORTURE IN GREECE: THE FIRST TORTURERS' TRLAL 1975, al 65 (1977); P Nikiforos Diamandouros, Regime Change and the Prospects for Democracy in Greece 1974-1983. in TRANSITIONS FROM AUTHORITARLAN RULE, supra note 1, at 138.

164. In Germany's border guards trials, suspension of sentences has been the norm. Of the 11 guards tried as of November 1992, only one has actually served time in jaul. See UPI. Nov. 3. 1992. avaulable in LEXIS, News Library, UPI File. Many prosecutions in the Czech Republic culminated in suspended or conditional sentences; only a handful of top Communists, such as Prague party chuef Mitoslav Stepan. served prison terms, lasting no more than two years. See 28 Communist Offictals Tried for Anticonstitutional Activity, CTK NAT'L NEWS WIRE, Sept. 21, 1994, arailable in LEXIS, News Library. CTK File; David Stamp, East Europe's Communist Elite Evades Prosecurors, REUTERS WORLD SERV . Feb. 14,1996 , available in LEXIS, News Library, Revwld File. In Romania, all of the former Communust leaders and police jailed in connection with the December 1989 massacres were released over a two-year period, either on health grounds or as a result of presidential pardons. See Romantans Protest over Communist Bosses' Release, REUTERS WORLD SERV., Sept. 21, 1994, arailable in LEXIS. News Library. Revwld File. In Bulgaria, Todor Zhivkov failed to serve time for embezzlement, while others in the regime have been pardoned. Similarly, in Albania, an amnesty law immunizes prior regime leaders sentenced for abuse of power, even the country's last Communist President. See Former Albanan President Has Sentence Cut By Three Years, AgENCE FRANCE PRESSE, Nov. 30. 1994, asailable in LEXIS. News Library. AFP File; see also Holmes, supra note 2.

165. Despite amnesties, criminal investigations would prowde a record relatung to pnor military rule Unlike other instances of the limited sanction discussed above. penalties would be dropped in advance, and on condition of confession to wrongdoing. SE HUMAN RIGHTS W ATCH-AMERICAS, UNSETTLED BUSERESS. 
postapartheid South Africa, for example, the declaration of amnesty for political crimes left a window for investigation and documentation of past wrongdoing. ${ }^{166}$ Contemporary international legal responses suggest a similar development in the tribunals convened to try atrocities committed in the former Yugoslavia and Rwanda. An emphasis on prosecution rather than punishment reflects the extraordinary nature of transitional justice. ${ }^{167}$

How does partial punishment lead to the common perception that justice was done? Consider the transitional criminal sanction. Ordinarily, the criminal sanction is justified by identifying and punishing individual offenders, while the limited criminal sanction is largely justified by distinctly transitional purposes. These transition-related purposes are both backward- and forwardlooking in nature. In successor trials in periods of political change, the criminal process condemns past wrongdoing. Formal criminal processes enable factfinding about past wrongdoing at a high standard of certainty. ${ }^{168}$ In periods of substantial political change, the heuristic purposes of the criminal investigation ${ }^{169}$ relate to the prosecution of offenses with a public dimension. Such trials clarify the criminal actions perpetrated under the prior regime. This knowledge about the past is often constructed for the first time in the context of the criminal trial. Identification and documentation of predecessor crimes, even where not fully individuated, enable the denunciation of the prior regime, ${ }^{170}$ as the society has to understand what happened before it can condemn and delegitimate. ${ }^{171}$ Furthermore, establishing knowledge of past

Human Rights In Chile at the Start of the Frei Presidency 1-4 (1994).

166. See Azanian Peoples Organization v. President of the Republic of South Africa, 1996 (8) BCLR 1015 (CC) (upholding constitutionality of amnesty act); Lourens du Plessis, Amnesty and Transition in South Africa, in DEALING WITH THE PAST: TRUTH AND RECONCILIATION IN SOUTH AFRICA 107 (Alex Boraine, Janet Levy \& Ronel Scheffer eds., 1994).

167. The pursuit of justice during wartime and in a fragile peace has consequences for the effective application of the criminal law, with implications for the possibility of adversarial trial and punishment. With the general absence of custody over the accused, problems gaining control over evidence, and constraints relating to the particular nature of these war crimes, it is expected that in virtually all cases, the International Tribunal will investigate and indict-and go no further. Indeed, the international criminal proceedings include a newly created hybrid procedure between indictment and conviction, exemplifying the limited sanction. The Tribunal rules provide for a special public indictment proceeding whereby, despite the absence of the accused, all of the underlying evidence is marshalled and publicly read and the indictment confirmed. See International Tribunal for the Prosecution of Persons Responsible for Serious Violations of International Humanitarian Law Committed in the Territory of the Former Yugoslavia Since 1991: Rules of Procedure and Evidence, R. 61, Feb. 11, 1994, 33 I.L.M. 484, 519 (1994).

168. The standard is "beyond a reasonable doubt." See John Calvin Jeffries, Jr. \& Paul B. Stephan III, Defenses, Presumptions, and Burden of Proof in the Criminal Law, 88 YALE L.J. 1325, 1327 (1979).

169. The heuristic purposes of the criminal trial lead back to an early sixteenth-century meaning of "prosecution," signifying to know precisely, to investigate, of to delve in detail into a matter. See 12 THB OXFORD ENGLISH DICTIONARY 662 (2d ed. 1989).

170. See generally HART, supra note 107, at 170-73 (discussing "denunciatory" theory of punishment); PUNISHMENT: SELECTED READINGS (Joel Feinberg \& Hyman Gross eds., 1975) (noting that punishment may be understood to express and ratify hatred that is excited by offenses).

171. On the social construction processes, see generally BERGER \& LUCKMANN, supra note 17, at 85-86, 107-09; Paul Connerton, How Societies Remember (1989); R.S. Perinbanayadam. SIGNIFYING ACTS (1985); and SHELDON STRYKER, SYMBOLIC INTERACTIONISM: A SOCIAL STRUCTURAL VISION (1980). 
actions committed under color of law and its public construction as wrongdoing is the necessary threshold to prospective normative uses of the criminal law.

The emergence of the limited sanction, therefore, signals a practical resolution of the central dilemma of transitional criminal justice: how to attribute individual responsibility for grave wrongdoing perpetrated under repressive rule. Without fully assigning individual guilt, the transitional criminal sanction nevertheless enables societies to recognize and condemn past wrongdoing perpetrated under repressive rule. ${ }^{172} \mathrm{~A}$ line is drawn between regimes, thereby allowing the political transformation to justify the transition. In the next Part, I turn to the constitutional responses in periods of change. Just as the transitional criminal response expresses a normative shift against past political power abuses, transitional constitutionalism also embodies a normative shift that delimits and transcends the political past.

\section{Constitutional Justice}

I now turn to the nature and role of constitutionalism in periods of political change. The central dilemma is how to reconcile the concept of constitutionalism with revolution: ${ }^{173}$ Revolutionary periods and their aftermath are times of political flux, and, as such, present tensions with constitutionalism, which is ordinarily considered to bind the political order. I begin by exploring the prevailing conception of the relation of constitutional to political change, and in particular, the modern claim for constitutionalism as foundational to democracy. Rather than arguing against the prevailing model, I contend that this model best describes an eighteenth-century view of the relation of the constitutional to the political. Hence it cannot capture the constitutional developments associated with political change during the last half-century, and needs to be supplemented. ${ }^{174}$ I will explore manifestations of constitutionalism in periods of substantial political change, and suggest that these give rise to another paradigm of transitional constitutionalism, which

172. It is my contention that the partial criminal sanction associated with pertods of politital transformation as a practical matter resolves the central successor justice debate over punishment or impunity. Neither full punishment nor full impunity charactenzes the transituonal sanction On the punishment/impunity debate, see generally the essays collecled in STATE CRimes: PUNISHMENT OR PardoN. supra note 1. See also Carlos S. Nino, The Dun to Punish Past Abuses of Human Rights Put into Context: The Case of Argentina, 100 YALE L.J. 2619 (1991): Jose Zalaquell. Balancung Elhucal Imperatwes and Political Constraints, 43 HASTDNGS L.J. 1425 (1992).

173. See supra note 9.

174. On the contemporary explosion in constitutionmaking, see Juho Faundez. Conshruttonalism. A Timely Revival, in CONSTITUTIONALISM AND DEMOCRACY: TRANSTIONS DN THE CONTEMPORARY WORLO

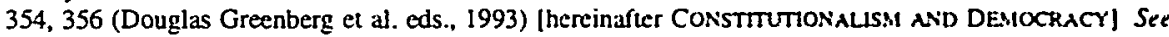
generally JON ELSTER \& RUNE SLAGSTAD, CONSTTUTIONALISM AND DENOCRACY (1988) (collecting essays that discuss relation of constitutionalism to democracy) 
provides an alternative account of constitutionalism in its third century. ${ }^{175}$

Constitutionalism in periods of political change stands in constructivist relation to the prevailing political order. Transitional constitutionalism not only is constituted by the prevailing political order, but is also constitutive of the perception of political change. ${ }^{176}$ These constitutions arise in a variety of different processes, and play multiple roles, serving conventional constitutions' aspirational purposes as well as other purposes in a transformative politics. Transitional constitutionmaking responds to past repressive rule, through principles delimiting and redefining the prevailing political system. They, in turn, effect further political change in the system. Such constitutions are simultaneously backward- and forward-looking, yet informed by a conception of constitutional justice that is distinctively transitional.

\section{A. The Prevailing Models}

To the extent that there has been theorizing about the nature and role of constitutionalism in periods of political change, it is commonly guided by competing realist or idealist perspectives. In the realist view, constitutions in periods of political change are thought simply to reflect the prevailing balance of political power, and are therefore epiphenomenal with, and arise by virtue of, the provenance of the political change. ${ }^{177}$ Under this view, it is not at all clear what distinguishes the making of a constitution from other lawmaking; what, if any, is the distinctive value of constitutions in the transition. As such, this approach offers little to the project of discerning the significance of the nature and role of constitutionalism in such periods. It follows that idealists have provided the dominant approach to exploration of constitutionalism in periods of political change.

175. In this Article, I propose an alternative paradigm, though I have not fully addressed all of the questions the proposed alternative paradigm raises for our understanding of constitutionalism, judicial review, or interpretive principles.

176. I refer here to the constructivist role of the constitutional document. See supra note 17. The use of the term constructivism in the analysis pursued here, see infra note 221, regarding constitutional change bears a certain similarity to the processes characterized by Rawls in his elaboration of gradual construction of political consensus. See RAWLS, supra note 6, at 90-99 (defining "political constructivism"). Rawls uses the term "political constructivism" to describe the gradual emergence of constitutional consensus as a result of a step-by-step decisionmaking process which narrows the area of parties' political differences. My analysis is constructivist in a somewhat different sense. While I agree with Rawls that new constitutional elements gradually emerge over time through the political process, I also claim that each change in the constitutional order changes the perspective of the participants, in turn changing their sense of what is politically possible and hence, the potential for constitutional consensus.

177. For the realist relation in political theory, see AREND LUPHART, DEMOCRACIES: PATTERNS OP MAJORITARIAN AND CONSENSUS GOVERNMENT IN TWENTY-ONE COUNTRIES (1984). For a contemporaty account, see Courtney Jung \& Ian Shapiro, South Africa's Negotiated Transition: Democracy, Opposition, and the New Constitutional Order, 23 POL. \& SOC'Y 269 (1995). For a realist account of the American Constitution, see CHARLES A. BEARD, AN ECONOMIC INTERPRETATION OF THE CONSTITUTION OF THE UNITED STATES (1913). 
In idealist constitutional theorizing, there is a normative claim for a strong connection between revolution and constitutionmaking. This strong connection first appears in the classical constitutional model in Aristotle's writings. ${ }^{178}$ Its modern expression appears in Hannah Arendi's work; ${ }^{179}$ and a contemporary articulation can be found in the work of Bruce Ackerman. ${ }^{180}$ Although these are different in important respects, there are affinities among these claims for the potential of constitutionmaking in effectuating political change. Below, these are considered as a triad in the intellectual history of constitutional politics.

Constitutionalism in periods of political transformation raises a basic tension between radical political change and the constraints on such change that would appear to be the predicate of constitutional order. In the idealist model discussed more fully below, the dilemma is reconciled by positing that constitutionalism functions as the very basis of the new democratic political order: a claim for constitutional foundationalism.

\section{The Classical View}

In the classical view, the constitution is understood as the state's fundamental political arrangements, the distinctive form or organization determining its structure and function. ${ }^{181}$ On this understanding, the constitution is at once normative and descriptive. ${ }^{182}$ Accordingly, in the classical view, revolutionary political change means constitutional change. Radical political transformation does not necessarily require a change in political leadership, representation, or membership, for it is the constitution that determines the identity of the polis. ${ }^{183}$

The classical account of constitutional politics is organic constitutionalism. In the classical view, the unity of the acts of revolution and constitution sheds light on the dilemma posed by the relation of constitutionalism to political change. Issues of justice remain, despite the move to a more democratic order.

178. See infra notes 181-83 and accompanying text. Although the classical understanding of constitutionalism generally is not considered to follow an idealist model. in ths view of the relation of constitutions to political change, it shares affinitues with the model discussed herem

179. See infra notes $185-88$ and accompanying text.

180. See infra notes $189-94$ and accompanying text.

181. In the Aristotelian view, constitutions are organic enuues. "The 'constutution' of a state is the organization of the offices ..." ARISTOTLE, THE POLITICS 187 (T.A. Sinclat trans. 1957), see also Charles H. MCllwain, Constitutionalism: ANCIENT aNd MOderN (1940) (describing ancient conception of constitution); Peter G. Stillman, Hegel's Idea of Consrinutionalism, in CoNsTtTutiosalis.M THE PHILOSOPHICAL DLMENSION 88 (Alan S. Rosenbaum ed., 1988) (discussing Anstotclian background of Hegel's constitutionalism).

182. See ARISTOTLE, supra note 181, at 198 ("[T]he assoctation which is a state exists not for the purpose of living together but for the sake of noble actions")

183. When the constitution changes, so does the polis "For the stale is a kind of assoctation-an association of citizens in a constitution; so when the constitution changes and becomes different in kund. the state also would seem necessarily not to be the same "ARISTOTLE, supra note 181. at 176 
Yet this account leads to the following questions: What is the relationship between reconstitution and political change? How does the new constitutional consciousness that defines the transition occur? The classical paradigm invites, but does not elaborate, a theory of the role of constitutionalism in the process of political change.

\section{The Modern Claim}

As distinguished from the classical view, modern constitutional theory emphasizes normative limits on state power of a structural and individual rights nature. ${ }^{184}$ The paradoxical role of modern constitutions is that they are considered to provide such limits on government despite periods of political change. How is one to reconcile the modern view of constitutionalism with constitutional change?

This is the dilemma of constitutionalism in the context of massive political change. For Hannah Arendt, the dilemma is resolved through a rethinking of the theory of constitutionalism. Rather than conceptualizing constitutionmaking as counterrevolutionary, and the opposite of political change, the "truly revolutionary element in constitution-making" is "the act of foundation."185 The Arendtian vision of revolutionary constitutionmaking draws heavily from American constitutionmaking. In this version, the apparent dilemma of the incompatibility of revolution and constitution disappears; the two political acts merge. The constitution is deemed the culmination of revolution; it is the "deliberate attempt by a whole people at founding a new body politic."186

The Arendtian account resolves the tension between revolution and constitutionalism through the mediating idea of foundation. ${ }^{187}$ The notion of a Founding elegantly reconciles the dilemma of political change with constitutional permanence. Though paradoxical, the very nature of the revolutionary change sought is the constitutive act of founding. American constitutionalism is distinguished by the paradox of constitutional change: It is revolutionary but lasting. The American posture toward its revolution ushered in a paradigm of constitutionalism as foundational to its democratic order. In this paradigm, constitutionalism was something other than its classical

184. Nevertheless, as we shall see, aspects of the classical conceptualization remain pertinent to the modern model, at least with regard to the reigning vision of the nature and role of constitutions in periods of political change. The classical view equates constitutions with political arrangements, with implications for the preeminent nature and role of constitutionalism in periods of political change.

185. ARENDT, supra note 9, at 142. For a good historical account of the development of constitutionalism between the English Civil War and the start of the twentieth century, see M.J.C. VILB, CONSTITUTIONALISM AND THE SEPARATION OF POWERS (1967).

186. ARENDT, supra note 9, at 143.

187. America's revolutionaries are described as "Founding Fathers," preoccupied with "permanence." In constitutionmaking, their purpose is "the deeply felt desire for an Eternal City on earth," and the wish to create a government which "would be capable of arresting the cycle of sempiternal change, the rise and fall of empires, and establish an immortal city." Id. at 232-34. 
sense, identified with the political order. It was also more than constitutionalism in the Magna Carta sense, as protective of negative liberties. The idea of constitutional democracy transcended protection of individual rights. An idealized constitutional model, foundational constitutionalism had the potential to embody the full normative sweep of the revolution. ${ }^{185}$

Building upon the Arendtian account, American constitutionalist Bruce Ackerman also makes a strong normative claim for constitutionmaking as foundational to democratic revolution. ${ }^{189}$ On this view, constitutionmaking is the necessary and final stage of liberal revolutions, a revolutionary "constitutional moment" of rupture from the ancien régime and the founding of a new political order. In the more contemporary constitutional theorizing, transformative constitutionmaking is not limited to the revolution; instead, there are potentially many more such constitutive moments. By extending the possibility of transformative constitutionmaking beyond the revolution, Ackerman contributes to the modern model a helpful categorical distinction between ordinary and constitutional politics. Within the "dualist democracy" framework, ordinary political change and constitutional change proceed on separate tracks, ${ }^{190}$ offering a neat resolution of the dilemma posed by constitutionalism in revolutionary periods. By a move defining "dual" categories of "ordinary" decisionmaking by government as opposed to "higher" lawmaking by "the People," the dilemma with which this Part begins, of constitutionalism and radical political change, seemingly falls away. ${ }^{191}$ In a dualist democracy, the dilemmas of constitutional beginnings, constitutional change, and constitutional review are made to disappear.

In the contemporary model, constitutionmaking relates to revolution through higher lawmaking, yet the distinction between higher and lower lawmaking remains ambiguous. What distinguishes higher lawmaking is a distinctive process, a particular timing, ${ }^{192}$ and heightened, deliberative decisionmaking. ${ }^{193}$ Foundationalists embrace the view that the special status of constitutional politics derives from its popular sovereignty, expressed

188. See id. at 157 (observing that "[c]onstutution-making" was considered by Framers as "the foremost and the noblest of all revolutionary deeds").

189. See ACKERMAN, supra note 1, at 61 ("If the alm is to transform the very character of constitutional norms, a clean break seems desirable . . . ."). For Ackerman, a "legutumate order" depends on "a systematic effort to state the principles of the new regime." Id. al 57 (cmphasis omilled) See generally CONSTTIUTIONALISM, IDENTITY, DIFFERENCE, AND LEOTRIACY (Afichel Rosenfeld ed., 1994) (analyzing relationship between constitutionalism and group identity). (1989).

190. See Bruce Ackerman, Constiturional Politics/Constitutional Law, 99 YALE L.J \$53. 461-62

191. See id.

192. Ackerman describes a constitutional onset period, a window of time for constututtonmaking or "constitutional moments." Constitutionmaking occurs prior to the establishment of other laws and institutions. See ACKERMAN, supra note 1 , at 55.

193. See id. at 14 ("The higher lawmaking track ... is designed with would-be revolutuonanes in mind. It employs special procedures for determining whether a mobilized majority of the culuenry give their considered support to the principles that one or another revolutionary movement would pronounce in the people's name."). 
through special constitutional convention processes. Constitutional politics is considered to correspond to a higher level of popular deliberation and consensus, and as such, is distinguishable from ordinary politics. This conception relies heavily upon the circumstances of the American Founding. ${ }^{194}$ In the prevailing contemporary paradigm, there is a strong claim for linkage between meaningful political change and constitutional change. The constitutional ideal is forward-looking; the purpose is to put the past behind and to move to a brighter future. Constitutionmaking is conceived as the foundation of the new democratic order.

Although its claims have been universalized, contemporary constitutional theory itself derives from a distinctive political context, specifically the eighteenth-century revolutions. Whereas the modern understanding does not define constitutionalism as a state's political arrangements, as in the classical understanding, the modern vision of constitutional politics is inextricably connected to particular revolutions and past political orders. ${ }^{195}$ Yet the view of constitutions as foundational to liberalizing political change offers only a theoretical resolution to the dilemma posed by postrevolutionary constitutionmaking. ${ }^{196}$ The dominant model is highly idealized, and as such cannot account for many constitutional phenomena associated with periods of political transformation. Instead, contemporary constitutionalism necessitates rethinking the prevailing theorizing about the relation of political to constitutional change. With constitutions in their third generation, constitutional precedents of the late twentieth century suggest that the model overstates the differences between ordinary and constitutional politics. As the next Section demonstrates, instances of constitutionalism in periods of substantial political change reveal diverse manifestations of constitutional politics.

194. This conception of constitutional politics depends on the view that the American constitutional conventions implied broad popular consensus. This claim is somewhat controversial, as some scholars suggest the constitutional ratification elections were marked by low voter turnout. See Peter Berkowitz, Book Review, 26 EIGHTEENTH CENTURY STUD. 692, 695 (1993) (reviewing 1 BRUCE A. ACKERMAN, WB THE PEOPLE: FoUNDATIONS (1991)).

Perhaps the processes considered to be predicates of constitutional foundationalism ought to be interpreted at a higher level of generality. Understood this way, low participation in constitutional ratification processes would not be fatal, so long as participation is better than the ordinary political participation of the time. As is discussed below, see infra text accompanying notes 223-24, a transitional perspective helps to explain why in periods of political upheaval, even limited popular participation may well suffice to legitimate constitutional transformation.

195. Although the American experience is thought to exemplify foundational constitutionmaking, in recent years a broader prescriptive claim has been leveled at other states in the process of transition. Thus, in The Future of Liberal Revolution, the foundationalist vision is extended to the contemporary postCommunist transitions. See ACKERMAN, supra note 1. Invoking the United States's constitutionmaking, Ackerman exhorts fledgling East European democracies to put aside ordinary politics and to cap their revolutions with a constitution. See id. at 193. For a related continental argument along Ackerman lines, see UlRICH PREUSS, Constitutional REvolution (Deborah Lucas Schneider trans., 1995).

196. Further, despite the contribution of contemporary constitutional theory to the political science debate over the criteria for liberalizing change, see supra text accompanying notes 10-13, this Article contends that liberalizing political change is associated with varieties of legal responses, beyond the constitutional. 


\section{B. A Transitional Counteraccount}

Here I propose another account of a transitional constitutionalism, which better captures constitutional politics associated with transformative periods. Constitutionalism in periods of radical political change reflects transitionality in its processes and normative commitments. In transitional constitutional processes, as developments in periods of political upheaval suggest, constitutions are not created all at once, but in fits and starts. Constitutionmaking often begins with a provisional constitution, predicated upon the understanding of subsequent, more permanent constitutions. Despite our ordinary notions of constitutional law as the most forward-looking and enduring of legal forms, transitional constitutionmaking is frequently impermanent, and involves gradual change. Many constitutions that emerge in periods of political transformations are explicitly intended as interim measures. Whereas the prevailing model conceives of constitutions as monolithic and enduring, some features of transitional constitutions are provisional, while others become more entrenched over time.

Transitionality has normative implications. Within prevailing theory, constitutionalism is commonly understood as unidirectional, forward-looking. and fully prospective. Once retrospective political understandings are included, the contemporary ideal becomes a poor model for transitional constitutional phenomena. The picture of a polis at constitutional point zero might have been appropriate for describing constitutionalism in the eighteenth century, but in the late twentieth century, constitutions associated with political change generally succeed preexisting constitutional regimes and are thus not simply created anew.

The construction of new constitutional arrangements in periods of radical political change is informed by a transitional conception of constitutional justice. Constitutional law is commonly conceptualized as the most forwardlooking form of law. Yet transitional constitutionalism is ambivalent in its directionality; for the revolutionary generation, the content of principles of constitutional justice relates back to past injustice. From a transitional perspective, what is considered constitutionally just is contextual and contingent, relating to the attempt to transform legacies of past injustice.

The study of constitutionalism in periods of political change suggests that transitional modalities vary in constitutional continuity. ${ }^{197}$ In its "codifying" modality, constitutionalism expresses existing consensus, rather than transformative purpose. In its transformative modality, in "critical" constitutionalism, the successor constitution explicitly reconstructs the political

197. The constitutional types proposed here, like Weberian tdeal types, do not lay claum to comprehending all constitutional phenomena but rather are offered for their help in understanding diverse constitutional phenomena. 
order associated with injustice. ${ }^{198}$ In another transformative form, where successor constitutions are used to return to the pre-predecessor constitutional order, such constitutionalism might be considered as "restorative." Where the successor constitution is a holdover from prior rule, one might consider these manifestations of constitutional continuity to be "residual." As review of illustrative constitutional developments in periods of political flux will show, many transitional constitutions incorporate aspects of more than one of the proposed types. These constitutional constructions mediate periods of political change.

My aim here is to interpret how states move from illiberal regimes to those that are more liberal, and to explore the role constitutions play in constructing these political changes. Below, I explore a number of cases that illuminate the nature and role of constitutionalism in periods of political transformation. The phenomenon of transitional constitutionalism goes back to ancient times, to the account of the constitution written after the Athenian revolution. ${ }^{199}$ With such historical transitions came the dilemma of squaring revolutionary political change with constitutionmaking. As we shall see, similar gradual constitutional processes take place in contemporary transitions.

\section{Brokering out of Authoritarian Rule}

In contemporary theorizing, the constitutional ideal is the culmination of the revolution, and the foundation of the new democratic order. The constitution somehow transcends its politicized origins, as constitutional politics transcends ordinary politics. By contrast, in the realist model, the nature and role of constitutions in negotiated transitions is largely conceived in political terms, and constitutions are conceived as extensions of ordinary politics. ${ }^{200}$ The two prevailing views take opposing positions on the place of constitutionalism in transformative politics. Neither model, however, adequately explains the nature of constitutional politics in contemporary political change. Examining the role of constitutions in periods of postauthoritarian rule illuminates the constructivist constitutional paradigm. ${ }^{201}$ While constitutionmaking is shaped by periods of radical political change, it also helps construct the political opening that allows transition.

Transitional constitutions broker the political shifts from authoritarian rule. They construct interim periods of substantial liberalizing political change,

198. In Parts I and II, I have described transformative legal responses in adjudicative and punitive forms. See supra text accompanying notes 33-37, 51-55, 104-08, 159, 172.

199. With the revolution, there was much debate about the nature of the desired political system. The debate culminated in two draft constitutions, one for the "immediate" crisis and another "for the future." See ARISTOtLe, The AtHENIAN Constitution chs. 29-33 (P.J. Rhodes trans., 1984).

200. For such a scholarly approach, see generally LINZ \& STEPAN, supra note 1, at 10; and O'DONNELL \& SCHMITTER, supra note 10.

201. For a discussion of this term, see supra note 176 and accompanying text. 
albeit not equivalent to a fully democratic order. Such constitutions are transitional in a number of senses: Their processes are plainly transient; their instruments are at least in part provisional. Such constitutions frequently suffer from features held over from the predecessor constitutional regime, features one might consider residual. Examples of such constitutions arise in Europe's historical negotiated transitions, as well as in the more recent wave of political change.

Although war provides the distinct break frequently considered a threshold to constitutional foundation, political shifts often occur without such ruptures, following prolonged and tortuous political negotiations. Transitional constitutions may emerge in the negotiated shifts out of authoritarian rule. Where the prior regime has not collapsed, and where the political shift occurs only as a result of negotiations, constitutions play a role not well accounted for within prevailing constitutional theory. ${ }^{202}$ Transitional constitutions are not simply revolution-stoppers, but they also play a role in constructing the transition. Early in the process, constitutions can jump start and instigate political change. Insofar as such constitutions destabilize rather than stabilize a political order, the transitional constitution's "disentrenching" role is analogous to the ordinary codifying constitution's "entrenching" role in this respect.

A contemporary illustration of the "disentrenching" constitution is postapartheid South Africa. Likened to a "historic bridge between the past of a deeply divided society characterised by strife, conflict, untold suffering and injustice, and a future founded on the recognition of human rights, democracy and peaceful co-existence... for all South Africans, ${ }^{203}$ South Africa's postapartheid Constitution exemplifies the uses of transitional constitutions following authoritarian rule. The Constitution embodies the political agreement and shift from minority rule over a disenfranchised population to a representative democracy. This constitutional pact enabled the political transformation to occur. To what extent can new constitutional legitimacy derive from an agreement ratified by the old apartheid-era Parliament? To what extent would the procedural linkage to the past regime compromise constitutional processes? The transitional constitution's origins in the apartheid regime are mitigated by its express provisionality. Constitutional change began with the old Parliament's enactment of an interim constitution, itself predicated upon the making of another, prospective constitution. ${ }^{204}$

202. For an account based on the path of the transition, see LONZ \& STEPAN, supra note !

203. S. AFR. CONST. ch. 15, \$251 ("National Unity and Reconciliauon") (1993). Other constututional arrangements reflecting such political compromise are provisions contemplating contunuation of the executive power, overseen by a Transitional Exccutive Council. See id. ch. 15. $\$ 235$.

204. The Constitution's preamble contemplates that it will be in force pending a final constutution. "Whereas it is necessary for such purposes that provision should be made for the promotion of national unity and the restructuring and continued governance of South Africa while an elected Constimtional Assembly draws up a final Constitution ...." Id. preamble (cmphasıs added). 
South Africa's 1993 transitional Constitution reflected complex modalities. Although generally provisional, it included binding constitutional principles. ${ }^{205}$ These binding principles related in large part to equality and representation rights. By reaffirming the protection of racial and ethnic groups, the Constitution transformed the legacy of racial prejudice in the move out of repressive apartheid, ${ }^{206}$ setting forth enduring liberal constitutional values. ${ }^{207}$

Transitional constitutions have been particularly useful in political movements from military rule. In the Southern European transitions, for example, the first post-Franco Constitution of 1978 helped to steer Spain out of military rule. ${ }^{208}$ The first successor Constitution's transitionality is reflected in the absence of a complete withdrawal of military power; while the military is made subject to constitutional rule, much about the new power sharing is left undefined. Similarly, the threshold question in Portugal's 1974 transition was whether the military would have a place in the successor regime. ${ }^{209}$ By creating a constitutional structure that made room for the Armed Forces, the first postrevolutionary Constitution enabled the transition

205. Indeed, the transition of the Constitution has been an ongoing question. The contemplated second Constitution was held invalid by the country's Constitutional Court pursuant to the transitional Constitution's animating principles. See In re Certification of the Constitution of the Republic of South Africa, 1996 (4) SALR 744 (CC) (S. Afr.). The revised final Constitution was certified shortly before this Article's publication. See id. In its structure, South Africa's first postapartheid Constitution shares affinities with Germany's postwar constitution. Despite its transitional nature, Germany's Basic Law also entrenched core provisions guiding the state's liberal political identity. See GRUNDOESETZ [Constitution] [GG] art. 79(3) (F.R.G.) (so-called perpetuity clause); infra notes 239-40 and accompanying text.

206. Schedule 4 sets forth "Constitutional Principles" not to be altered or contradicted by any subsequent constitution, such as:

The Constitution shall prohibit racial, gender and all other forms of discrimination and shall promote racial and gender equality and national unity.

$\ldots$. .

The legal system shall ensure the equality of all before the law and an equitable legal process. Equality before the law includes laws, programmes or activities that have as their object the amelioration of the conditions of the disadvantaged, including those disadvantaged on the grounds of race, colour or gender.

S. AFR. INTERIM CONST., Act 209 of 1993, sched. 4, pts. III \& V, reprinted in DION BASSON, SOUTH AFRICA's INTERIM CONSTITUTION: TEXT AND NOTES (1994).

207. Indeed, the way the constitutional consolidation process is expected to work was clarified in the Constitutional Court's decision invalidating the subsequent proposed constitution. See supra note 205.

208. See ANDREa Bonme-Blanc, Span's Transtion to DemocracY: THE PoltTics of Constitution-Making 31 (1987); Jordi Solé Tura, Iberian Case Study: The Constitutionalism of Democratization, in CONSTITUTIONALISM AND DEMOCRACY, supra note 174, at 287, 292-94. See generally O'DONNELL \& SCHMTTER, supra note 10, at 37-72. The subjection of the military to civilian rule is incomplete, however: the Constitution contemplates military power to protect the constitutional order. According to Article 104 of the Spanish Constitution,

The Security Forces and Corps which are instruments of the Government shall have the mission of protecting the free exercise of rights and liberties and that of guarantecing the security of the citizens. ...

$\ldots$

An organic law shall determine the functions, basic principles of action and the Statutes of the Security Forces and Corps.

CONSTITUCIÓN art. 104 (Spain).

209. For an account of the transition, see Maxwell, supra note 130, at 109-37. 
to democracy by structuring the allocation of military and civilian power. ${ }^{210}$ Throughout Latin America, transitional constitutions have served to broker the way between military and civilian regimes. An example is Brazil after military rule. $^{211}$ Through the Constitution's limits on state power that previously led to abuses, the authoritarian structure was reconstructed to effect political transformation. $^{212}$ The Brazilian Constitution of 1988 was concededly provisional: After five years, there was to be constitutional review with an eye to amendment. According to the reigning constitutional model, the provisional nature of the 1988 Brazilian Constitution defeated a written constitution's basic purpose: to preserve a distinct vision of state power over time. ${ }^{213}$ From a transitional perspective, this critique is inapposite. Where a political regime is not yet consolidated, it makes little sense to insist on constitutional permanence. To the contrary, the constitutional opening may well be contingent upon its transience. The possibility of reform associated with the first interim constitution is predicated upon and bounded by the assumption of a deferred, more plenary constitutional process. Chile's contemporary Constitution dramatically illustrates this possibility. Its 1991 Constitution helped to extricate the country from rule by military dictatorship, but only at a constitutional cost. The first transitional Constitution maintained some residual continuity with past rule by accommodating military dictatorship within its constitutional structure. This transitional change enabled civilian/military power sharing and the move to a more liberal democratic regime. ${ }^{214}$

210. See Tura, supra note 208, at 291-92.

211. For an overview of the transition and an analysis of the 1988 Constitutuon. see Keith S. Rosenn. Brazil's New Constitution: An Exercise in Transient Consfitusionalism for a Transitional Sociery, 38 Ali. J. COMP. L. 773 (1990).

212. For examples of new limits placed on the exercise of states of siege, see Anucles 136 and 137 as well as the presidential lawmaking associated with states of emergency. The Constututuon of Brazil provides: "Legislative power is exercised by the National Congress ...." ConstITUICAO FEDERAL [Constitution] [C.F.] art. 44 (Braz.). Article 62 provides:

In important and urgent cases, the President of the Republic may adopt provisional measures that have the force of law; however, he must immediately resubmit them to the National Congress which, if it is in recess, shall be convenod in special session in order to meet withun 5 days ....

$$
\cdots \cdot
$$

Provisional measures shall lose their effectiveness as of the dite of publication if they are not converted into law within 30 days from the date of their publication, and the Nattonal Congress shall make provisions to regulate any legal relationship that may stem from such measures.

Id. art. 62 .

213. For an example of this argument, see Rosenn, supra note 211. at 783.

214. In a delicate series of constitutional amendments negotsaled between the ruling military junta and the opposition groups lay the glimmerings of the retum to democracy in Chile. The consutuuonal amendments limited the power of the military, as well as other unstututuons supporing mulitary rule, and lifted the ban on opposition parties in the Senate. For a bnef overview of the negouations, see Chule: Chronology 1988-1991, in IV CONSTITUTIONS OF THE COUNTRIES OF THE WORLD 33-36 (Alber P Blaustein \& Gilbert H. Flanz eds., 1991). Article 9 on political parties was amendod, as were Arucles 95 and 96 , which had the effect of weakening the National Secunty Council. 
Colombia provides a good historical illustration of disentrenching constitutional change. Analogized to a treaty, the recent Constitution of Colombia truly enabled the peace. A longstanding political crisis between the government and the guerrillas exploded in the 1980s with the partial collapse of the state. ${ }^{215}$ The political crisis signaled the need for overhaul of the constitution, but the problem was how to enact constitutional reforms without the support of the Congress and in contravention of existing constitutional law. ${ }^{216}$ As is characteristic of transitional constitutionmaking, Colombia departed from its preexisting constitutional procedures to allow interim constitutional change, pending greater constitutional reforms. ${ }^{217}$ These ingenious measures constituted the transition; they opened a political space and provisionally constrained the political process in a way that permitted the shift to freer democratic rule. The Colombian Constitution embodied a boldly constructive mechanism for political transformation. Self-consciously provisional, it was intended to restructure an unstable political order. ${ }^{218}$ Transitory provisions laid down rules for the first free elections, reconstituted the political order, granted amnesty for past political crimes, ${ }^{219}$ and reintegrated demobilized guerrillas. Constitutionalism first implied disentrenchment, followed by reconstitution.

The transitional constitutions discussed above are explicitly political. For example, they all ratify features of political agreements. ${ }^{220}$ The politicized nature of such constitutions is also evident in their affinities with transitional criminal measures. In shifts out of harsh rule, transitional constitutions often ratify amnesties of past political offenses. Thus in transitional times, constitutions delineate the parameters of what is permissibly political and, consequently, what is unjust. In the context of these political changes, constitutions serve not as the culmination or endstage of revolution but rather as actors in the construction of the transformation. As such, these constitutions

215. See Daniel T. Fox \& Anne Stetson, The 1991 Constitutional Reform: Prospects for Democracy and the Rule of Law in Colombia, 24 CASE WV. REs. J. INT'L L. 139, 143-44 (1992).

216. See William C. Banks \& Edgar Alvarez, The New Colombian Constitution: Democratic Victory or Popular Surrender?, 23 U. MLAMI INTER-AM. L. REV. 39, 55 (1991).

217. Going outside prevailing procedures under Colombian law, a referendum on constitutional change was put on the ballot in the May 1990 elections. See id. at 56-57. By this referendum, a popular decision was made to elect a constituent assembly to redraft the constitution. The referendum was followed by elections to the constituent assembly. See id. at 57. By then, the former guerilla movement had demobilized, had made a strong showing as an independent force in electoral politics, and ultimately would take an activist role in the constitutionmaking. See Fox \& Stetson, supra note 215, at 142, 145.

218. Because the central abuses lay in the allocation of executive/legislative power, the new Constitution gave the President extraordinary legislative powers, as well as creating a new "mint-congress," to take effect until the installation of a new congress.

219. See CoNstrtución transitory art. 6 (Colom.) (describing National Constituent Assembly); id. transitory art. 39 (vesting President with "extraordinary powers" to "issue decrees with the force of law" for three months); id. transitory art. 30 (concerning amnesties).

220. Political agreements are often contemporaneous with transitional constitutions and directive of subsequent constitutional change. As such agreements are generally not subject to broad political participation, this challenges the sense in which constitutionmaking is democratic. 
are frequently explicit provisional measures that facilitate political transformation. Successor constitutions delimit provisional political agreements and structures, creating a new political space constructive of the political transition. The superentrenching of certain critical constitutional norms reflects boldly constructive responses to past repressive rule. While the concededly transitional nature of the balance of these constitutions chiefly relates to structures of state power, the normative principles relating to individual rights norms are intended to be transformative and enduring, guiding the state's liberal democratic identity. There is a higher law, higher even than the constitution, that could be understood as the "constitution's constitution."

Transitional constitutionmaking, to some extent, provides a reflection of prevailing ideas about the state and political change. Unlike the dominant constitutional model, the transitional constitution is flexible in the entrenchment of norms, as seen in the emergence of interim or provisional constitutional phases regarding controversial questions of a constitutional nature. Over time, a first round of constitutional changes can further transform the political scene, enabling greater constitutional change. ${ }^{22 !}$ Finally, rather than expressing existing popular consensus, these constitutions' normative principles are best accounted for within a transitional account, as their very purposes are bound up in constitutionalism's transformative possibilities.

\section{Victor's Constitutional Justice}

The course of constitutionmaking after war appears to follow the idealized sequence of rupture and new beginnings. Although postwar constitutionalism implies a "clean break," it hardly implies the superdemocratic processes and popular sovereignty predicates of the contemporary constitutional model. Two illustrations discussed here are postwar West Germany and Japan, which adopted constitutional schemes following Allied victory and unconditional surrender. Both the West German and the Japanese Constitutions illustrate a distinctive transitional constitutionalism: the "victor's" constitution. To varying degrees, these are imposed constitutions. The postwar Constitutions' transitional purposes are seen in their heightened critical function: As is reflected in their substantive mandates, both West Germany's Basic Law and Japan's 1946 Constitution were expressly designed to transform past repressive legacies.

Perhaps the extreme case of victor's constitutional justice is the postwar Japanese Constitution. Adopted under almost absolute American domination, drafted by a small group under General Douglas MacArthur's direction, and

221. While the constructivist constitutional paradigm proposed here is drawn from unductive reasoning. based upon comparative analysis of a variety of socictal practuces in penods of polutucal change, 1 bears similarities to the theoretical model of gradual constitutional consensus-building processes proposed by Rawls. See RAWLS, supra note 6, at 133-72. 
forced upon the Japanese Parliament for ratification, ${ }^{222}$ the 1946 Japan Constitution cannot be understood as an expression of popular sovereignty in this occupation context. ${ }^{223}$ Despite undemocratic constitutional beginnings, the postwar Constitution's continuing authority suggests that other mechanisms operate to legitimate victors' constitutions over time. To some extent, the victor's constitution exemplified by postwar Japan is simply a more extreme version of a constitutional process that, in this century, is common to transitions. In periods of political transition, after war or repressive rule, constitutional processes are often mediated by occupying powers or other influential countries. ${ }^{224}$ The leverage of the mediating actor affects the sense in which constitutionmaking processes represent popular sovereignty. Perhaps the legitimacy of postwar constitutions devolves upon their mandates, and the degree to which these constitutional processes nurture democracy and create norms to shape the transition's political structure. In this respect, much of the postwar Japanese Constitution reflects a transitional modality that I previously have characterized as transformative and critical. ${ }^{225}$ The Constitution's explicit purposes were to transform the political tendency toward militarism and imperial nationalism. Thus, Japan's warmaking power is renounced completely, ${ }^{226}$ and its Emperor reduced from a near deity to a figurehead. ${ }^{227}$ There is a broad attempt to displace the prior legal regime, and to move Japan to a formally more egalitarian democracy. ${ }^{228}$

The 1946 Japanese Constitution evinces several critical aspects in presenting a retributive response to the prior regime. The Constitution's delimiting of the Emperor's powers appears as an express alternative to criminal justice. ${ }^{229}$ In limiting the Emperor's powers, the new Constitution

222. For a comprehensive account of Japan's constitutionmaking history, sec KYOKO INOUB, MACARTHUR's JAPANESE CONSTITUTION: A LINGUISTIC AND CULTURAL STUDY OF ITS MAKINO (1991).

223. The significance of popular participation in constitutionmaking may well be less in states with a tradition of authoritarian rule. Like MacArthur's constitution, Japan's previous Meiji Constitution had also been drafted in private by a handful of elites. See id. at 51 .

224. Perhaps the mildest form of such mediation is the contemporary constitutional advisory role played by international, national, and nongovernmental actors. For an example from the post-Communist transitions, see Holmes, supra note 2. For an indictment of "expert" constitutions for their failure to establish authority and stability, see ARENDT, supra note 9, at 144-45.

225. See supra note 198 and accompanying text.

226. See KENPŌ [Constitution] ch. III, art. 9 (Japan).

227. Chapter I of the Japanese Constitution concerns the Emperor. Under Article 1, he is made the "symbol of the State." Jd. ch. I, art. 1. Article 3 states: "The advice and approval of the Cabinet shall be required for all acts of the Emperor in matters of state, and the Cabinet shall be responsible therefor." $I d$. ch. I, art. 3. Article 4 states: "The Emperor shall . . . not have powers related to government." Id. ch. I, art. 4.

228. For example, Article 14 states: "All of the people are equal under the law and there shall be no discrimination in political, economic or social relations because of race, creed, sex, social status or family origin."; "Peers and peerage shall not be recognized."; "No privilege shall accompany any award of honour ...." Id. ch. I, art. 14.

229. This response evokes the affinities between criminal justice and constitutional lawmaking in periods of political upheaval. As discussed earlier, constitutions have been used to recognize past criminal wrongdoing, while also pardoning such offenses. In such instances, the constitution circumscribes the parameters of permissible democratic politics. See supra notes 172, 219-20, and accompanying text. 
provided a compromise for the threat of punishment that had destabilized the imperial role. ${ }^{230}$ Like the eighteenth-century trials of kings, constitutional limits on imperial sovereignty drew a normative line between prior rule and the new regime. Successor constitutionmaking, like trials, offered formal, public legitimation of the transformation from the implicated political systems. 231

Victor's justice would not be as complete in Germany. Although Germany surrendered unconditionally, subsequent Cold War political change gave it leverage over its constitutional reconstruction. The occupying powers instigated but did not control constitutional reconstruction. Thus, despite Allied calls for the convening of a constituent assembly to draft a constitution to be adopted by popular plebiscite, Germany resisted the demand for a permanent constitution, adopting instead the so-called Basic Law, which was avowedly enacted as a transitory document. ${ }^{232}$ Hence the Basic Law's provisionality cannot be fully accounted for within the prevailing constitutional model. The proposed paradigm of transitional constitutionalism, however, illuminates the Basic Law's normative commitments. Its dominant purpose was transformative: to counter the abuses of power that enabled the past regime's evil. ${ }^{233}$ As such, the Basic Law follows the critical constitutional type introduced above. Further, unlike the eighteenth-century constitutions, in the Basic Law the normative constitutional concern regarding the potential threat to democracy transcends the abuses of state power to the polity itself. The sense in which this concern responds to the prior repression is best explained from a transitional perspective.

The meaning of constitutional justice from a transitional perspective is conceptualized and constructed in terms of prior constitutional and political regimes. In Germany, the lessons of the Weimar Republic steered the postwar constitutional course. ${ }^{234}$ Responding to this legacy, the Basic Law aggressively countered the fascist tendencies in the political order that culminated in Nazi dictatorship. In the Basic Law, presidential powers are rendered largely symbolic. Similar to the postwar Japanese Constitution's

230. See lan Buruma, The Wages of Gullt 153-76 (1994).

231. See supra Pan II for the comparative role of tnals in transition. See generally WAR CRtMES BIBLIOGRAPHY, supra note 129, at 257-82 (listing sources on war cnmes tnals in Asta)

232. See BASIC LAW FOR THE FEDERAL REPUBlic OF GerMaNy (1949). translated in PETER H MERKL, THE ORIGIN OF THE WEST GERMAN REPUBLIC app. al 213 (1963) [hereinafter BasIC LAW] ("IT] he German people ... has, by virtue of its constituent power, enactod this Bastc Law to give a new order to political life for a transitional period.") (emphasis added). The Basic Law was untended to be ratufied by state legislatures, with plenary constitutionmaking processes postponed unlul after the country's prospective reunification; but the constitutional moment of raufication never amved. See MIERKL, supra. at 3-19 (1963); see also CONSTITUTIONAL POLICY DN UNIFIED GerMaNY (Klaus H Goetz \& Peter J Cullen eds., 1995) (collecting aricies on German constitutionalism).

233. See MERKL, supra note 232, at 22-24, 80-89.

234. Fascism's success is commonly atuributed to the Weimar constitutuonal scheme, which combined a strong executive with a weak legislative branch, enabling the nse of subversive movements See. e $g$. id at 23 . 
treatment of its wartime Emperor, the Federal President is bereft of power, the wartime institution deposed, and power diffused more broadly to the Parliament. ${ }^{235}$ As with Japan's postwar constitution, Germany's Basic Law also reflects the sense in which criminal and constitutional mechanisms posit fully alternative responses to prior evil rule. Both punishment and constitutionmaking construct normative limits on past abuses of state power. ${ }^{236}$ Detailed rights provisions prohibit the racial and religious persecution rampant under the Nazi regime. ${ }^{237}$ While such equality rights are common to modern constitutions, the Basic Law goes beyond the conventional protections. The normative structure created by the Basic Law has been characterized as a "militant" democracy. ${ }^{238}$ "Militant democracy" may appear to be a paradoxical construct, but it captures the sense of the instrument's primarily transformative purposes. ${ }^{239}$ Transitional constitutionalism operates differently from our prevailing intuitions about the role of constitutionalism. Protection against similar future persecution is not limited to the enumeration of individual rights; transitional constitutions set limits not only upon the political majority, but also upon an illiberal polity. The view that fascism was a political expression of a populist nature leads to the attempt to constrain such expression, even where it is that of a supermajority; a seemingly paradoxical endeavor in the service of constitutional democracy. Adopted as a provisional constitutional instrument, the Basic Law nonetheless reflects varying degrees of transitionality and constitutional entrenchment. Some constitutional norms are provisional, whereas others relating to the instrument's animating normative liberal values, such as protection of individual rights of dignity and equality, are utterly unamendable and superentrenched, ${ }^{240}$ thereby defining

235. Chapter V, entitled "The Federal President," consists of eight articles. Article 61 relates to impeachment. See BASIC LAW, supra note 232, art. 61; see also MERKL, supra note 232, at 178-82.

236. Postwar sovereignty would be restored when the Allies ended occupied trials, and Germany committed to constitutionmaking. For a historical account, see BUSCHER, supra note 161.

237. For example, Article 3(3) provides: "No one may be prejudiced or privileged because of his sex, his descent, his race, his language, his homeland and origin, his faith or his religious and political opinions." BASIC LAW, supra note 232, art. 3(3). Article 4(1) provides: "Freedom of faith and conscience and freedom of creed in religion and in philosophy of life (weltanschauliche) are inviolable." Id. art. 4(1).

238. DONALd P. Kommers, THE CONSTITUTIONAL JURISPRUDENCE OP THE FEDERAL RePUBlic of GERMANY 218 (2d ed. 1997). For an illustration of this constitutional principle in a decision of the country's Federal Constitutional Court, see Socialist Reich Party Case, Bundesverfassungsgericht [BVerfOE] 2, 1 (1952) (F.R.G.), translated in KOMMERS, supra, at 218. See also Donald P. Kommers, German Constitutionalism: A Prolegomenon, 40 EMORY L.J. 837, 854 (1991).

239. Although the Basic Law placed democratic conditions on both individuals and political partics, antiliberal elements were excluded from political life. A militant constitutional order is vigilant not only to the excesses of state power, but also to those of popular sovereignty. Thus political parties which "by reason of their aims or the conduct of their adherents, seek to impair or do away with the free democratic basic order or threaten the existence of the Federal Republic of Germany, shall be unconstitutional." BASIC LAW, supra note 232 , an. XXI, $\S 2$. Moreover, individuals forfeit their constitutional rights to expression where there is abuse of the use of speech, press, teaching and assembly "in order to undermine the free democratic basic order." Id. art. XVIII.

240. See BASIC LaW, supra note 232, art. LXXIX, $\$ 3$ (setting forth "eternity" or "perpetuity" clause referring to unamendability of "basic principles" laid down in Articles I and XX). 
the state's liberal political identity. ${ }^{2-1}$ Germany's Basic Law, as interpreted by the country's Constitutional Cour, becomes the guardian of the liberal state.

These postwar constitutions illustrate constitutionalism in its third century. In the move from authoritarian rule, set against a backdrop of prior constitutional regimes, such constitutionalism plays a distinctive critical function: It is boldly reconstructive of past constitutional tendencies identified with illiberal politics. While postauthoritarian constitutionmaking often lacks the legitimacy afforded by full constitutional processes predicated in the foundationalist model, delegitimation of the predecessor regime clears the path for constitutional reconstruction. The postwar constitutions pose a problem for the prevailing idealized constitutional model. These constitutions can hardly be understood as full-blown expressions of a heightened popular consensus and revolutionary agenda. Indeed, such constitutions would often seem to be just the reverse. The absence of popular consensus in constitutionmaking processes, and the failure of heightened democratic commitments implicit in the view of constitutions as political foundations, is also borne out in such constitutions' normative principles. Modern constitutions are generally conceived and designed as structures to constrain state power, but transitional postauthoritarian constitutions counter illiberal tendencies more broadly. In realist theorizing, constitutions would be largely explained in terms of the balance of political power. Yet the notion of constitutionalism as a product of the balance of political power does not well explain cases of total transition, such as those following war, unconditional surrender, or other regime collapse. Further, both the idealist and realist models assume that the triumph of the revolutionary regime over its predecessor implies fully forward-looking constitutionmaking. As these constitutional normative structures are not well explained by idealized types, nor by explanations in terms of current political forces, they illuminate a distinctive transitional constitutionalism.

\section{Velvet Revolutions and Their Constitutions}

What are the implications for constitutionalism of velvet revolutions? Like many of the postauthoritarian transitions, the fall of Communism occurred through the collapse of the prevailing Communist regime or negotiated political change. ${ }^{242}$ Political changes in the former Soviet bloc were largely peaceful, and hence known as velvet revolutions. As such, constitutional change in the

241. Compare discussion of the South African postapartheid 1993 Constitution, supra notes 203-07 and accompanying text.

242. See Huntington, supra note 2, at 23-24. On the East European transitions, see generally

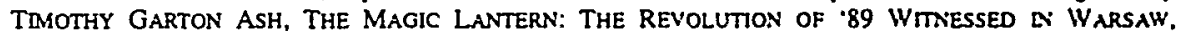
BUDAPEST, BERLIN, AND PRAGUE (1990); EASTERN EUROPE IN REVOLUTION (Ivo Banic ed., 1992); JOHN FEFFER, SHOCK WAVES: EASTERN EUROPE AFTER THE REvolutions (1992); and KeN JOWm, NEW WORLD DISORDER (1992). 
area did not follow the dominant constitutional model patterned on eighteenthcentury-style revolution. The velvet revolutions generally lacked clean breaks, and as such did not culminate in constitutional change of a foundational sort. Years after the political changes, and in much of the region, the story is of constitutional continuity. What emerges is an initial transitional constitutionalism displaying aspects largely of a residual type. Even states in the more advanced stages of economic reform still rely on amended Communist-era documents. ${ }^{243}$

What does smooth political change-or velvet revolution-imply about the attendant constitutional change? Whereas revolution by violent means implies rupture in the constitutional regime, velvet revolution implies forced continuity instead. The dilemma of the tension between constitutionalism and political change disappears, for there is no discontinuity, only constitutional continuity. As in other negotiated transitions, constitutions play a role in ratifying the agreements constructing the political shift, ${ }^{244}$ as well as in restoring the prerevolutionary constitutional order. ${ }^{245}$

243. Hungary, for example, is still functioning under a much-amended Constitution of the Sovict period. See Andrew Arato, The Constitution-Making Endgame in Hungary, E. EUR. CoNST. REV., Fall 1996, at 31. See generally Péter Paczolay, The New Hungarian Constitutional State: Challenges and Perspectives, in CONSTITUTION MAKING IN EASTERN EUROPE 21 (A.E. Dick Howard ed., 1993); Edith Oltay, Toward the Rule of Law-Hungary, RFE/RL REs. REP., July 3, 1992, at 16. Poland has been functioning under the so-called Little Constitution, an interim constitution limited to clarifying the structure of the prevailing political system. Portions of its 1952 Constitution, particularly the individual rights provisions, still prevail. See Andrzej Rapaczynski, Constitutional Politics in Poland: A Report on the Constitutional Committee of the Polish Parliament, 58 U. CHI. L. REV. 595 (1991). As of the date of this Article's publication, there was still no consensus on a charter of rights and frecdoms. See Andrzej Rzeplinski, The Polish Bill of Rights and Freedoms: A Case Study of Constitution-Making in Poland, E. EUR. CONST. REV., Summer 1993, at 26; see also Wiktor Osiatynski, A Bill of Rights for Poland, E. EUR. CONST. REV., Fail 1992, at 29. In Russia, the struggle over the legitimacy of the country's Soviet-era Parliament and Constitution led to a crisis culminating in violent extraconstitutional resolution. See generally Dwight Semler, The End of the First Russian Republic, E. EUR. CONST. REV., Fall 1993/Winter 1994, at 107; Vera Tolz, The Moscow Crisis and the Future of Democracy in Russia, RFE/RL REs. REP. Oct. 22, 1993, at 1. In Estonia, 1992 elections were held in accordance with the Communist Constitution of 1938. The September 20,1992, elections for President and members of the Parliament were conducted according to the 1938 Constitution. See Constitution Watch, E. EUR. CONST. REV., Fall 1992, at 2, 5. In Albania, as of the fall of 1994, a new constitution had not yet been enacted. See Constitution Wasch, E. EUR. CONST. REV., Spring 1994, at 2. A transitional "Law on Major Constitutional Provisions" remains in force.

244. See generally Paczolay, supra note 243, at 21; Jon Elster, Constitutionalism in Eastern Europe: An Introduction, 58 U. CHI. L. REv. 447 (1991) (presenting account and analysis of transition 10 constitutional democracies in Eastern Europe). For the majority of states in the former Soviet bloc, the move to a democratically elected regime occurred through round table talks between the Communist Party and opposition. See generally THE ROUNDTABLE TALKS AND THE BREAKDOWN OF COMMUNISM (Jon Elster ed., 1996) (providing comprehensive account of bargaining process enabling transition). In Hungary, the process of concluding the negotiations with a draft constitution took place in a process continually threatened by the possible breakdown of political consensus. As such, the constitutional amending process lacked prolonged deliberation, ending in speedy consideration in the Parliament where the amended document was adopted. See Arato, supra note 88, at 685.

245. See András Saj6, Preferred Generations: A Paradox of Restoration Constitutions, 14 CaRdozo L. REv. 847, 853-57 (1993). For a discussion regarding the phenomena of constitutional continuity in East Central Europe, see generally ULRICH K. PREUSS, REVOLUTION, FORTSCHRITT UND VERFASSUNo (1990); and Andrew Arato, Dilemmas Arising from the Power to Create Constitutions in Eastern Europe, in CONSTITUTIONALISM, IDENTITY, DIFFERENCE AND LEGTIMACY, supra note 189, at 165. 
Post-Communist constitutionalism reveals several affinities between theories of political and constitutional change. Just as political change occurred in domino fashion after the Soviet collapse, so too there is a domino quality to the constitutionalism prevalent throughout the region. Constitutional change occurred through negotiation; as such, it did not rely on popular sovereignty. On the contrary, the first such constitutional change occurred through bargaining conducted by representatives of a political elite. In the velvet revolutions, the predecessor regime was dislodged rather than overthrown. Constitutional amendments ratified the move from one political regime to another. In the negotiated transitions, the first constitutional changes involved disentrenching the prior political order from power and constitutionalizing the move to power sharing. ${ }^{246}$ Thus post-Communist constitutional change has less to do with delimiting state power than party power. This first round of constitutional change was provisional, reflecting affinities with other transitional legal responses. Constitutional processes in the region were not the culminating stage in revolutionary change, but instead were inextricably linked to gradual political processes. Constitutional change was so closely associated with political change that it implied a constitutional politics not readily distinguishable from ordinary politics. ${ }^{247}$ Nevertheless, the legitimacy of constitutional changes did not appear to be affected by this similarity. Rather than following the ideal of constitutionmaking as a foundational expression of a preexisting political consensus, here constitutional amendment comes first, laying a foundation for further political change. Thus the constitutionalism of the velvet revolutions challenges foundationalist understandings of the relation of constitution and revolution.

There is another face to post-Communist constitutionalism, that of "restoration" constitutionalism. In the former Czechoslovakia, the revolution began in November 1989 with a demonstration commemorating the fiftieth anniversary of the closing of the Czech universities by occupying German forces. These auspicious beginnings underscored the deep historical sense of political occupation pervading the region. Upon the end of political occupation, there was a virtually automatic revival of the constitutional order that preceded the occupation. I call this dimension of transitional constitutionalism

246. Throughout the region, constitutional amendments eliminated the constitutionally pnvileged role of the Communist Party. The amendment processes in Hungary and Poland, for example, first and foremost took power away from the dominant Communist party, and sought to protect those in the polatucal minonty See Elster, supra note 244, at 457-58. In this regard, there are affinities with Germany's postwar Basie Law and the constitutional responses to totalitarianism.

247. Hungary's constitutional change is explicitly described as "transituonal"; so too the amendments to the Poland's 1949 Stalin-era Constitution known as "the Litule Constitutuon." Only five years after the revolution would Poland and Hungary begin to effoct more comprehensive consututuonal change, toward a bill of rights. Regarding Hungary, see Constinusion Wasch: Hungan. E. EUR. CONST. REV . Winter 1996. at 10; and supra note 243. Reganding Poland, see Constirution W'asch: Poland. E. EUR. CONST REV., Winter 1996, at 16-17. 
"restoration constitutionalism.".248 In the post-Communist bloc, restoration constitutionalism is rampant, implying a partial return to the pre-Bolshevik constitutional regime. ${ }^{249}$ Turning to restoration constitutions enabled countries to eliminate the constitutional regime associated with Communism. However, some countries returned to these old constitutional structures out of nostalgia and the desire for stability. ${ }^{250}$ Indeed, the very term "restoration" suggests the normative pull of the old order. Yet the post-Communist restorations offer dubious stability. Although these regimes may be expressions of traditional and national identity, they can hardly be regarded as an expression of true existing social consensus. Nevertheless, restoration constitutions have a normative pull that manages to evade the dilemma of constitutional beginnings. To the extent that such transitional constitutions are restorative, there are seemingly no constitutional beginnings, only returns. Such constitutionalism eliminates the tensions inherent in constitutionalism in periods of political change.

These cases illustrate varying modalities of transitional constitutionalism. Where there is constitutional change, it has tended to occur not through special bodies or procedures but in piecemeal fashion, through negotiations and ordinary political processes. Such constitutional change has been inextricably bound up with the processes of political change. Much of the remaining constitutional order is residual, reflecting constitutional continuity. To the extent that there has been transformative constitutional change away from the prevailing political order, often it has been to revert to the constitutional and political order that prevailed before totalitarianism, a form of restoration constitutionalism.

\section{The American Constitution: A Transitional Account}

Finally, I turn to the American Constitution, the paradigmatic case of foundational constitutionmaking. Despite this status, the American case does not completely fit the dominant theoretical model, suggesting that the model is incomplete and must be supplemented.

248. Restoration has certain affinities with the notion of "reactionary" change. See ALBERT O. HIRSCHMAN, THE RHETORIC OF REACTION 1-10 (1991) (discussing "reactionary" change).

249. In the former Czechoslovakia, the Constitution of 1920 became the basis of drafts for the "new" Constitution after the revolution. See Lloyd Cutler \& Herman Schwartz, Constitutional Reform in Crechoslovakia: E Duobus Unum?, 58 U. CHI. L. REV. 511, 531-36 (1991). In Latvia, a constitutional hybrid of the 1922 Constitution, together with laws passed by the current parliament, has been in force since May 1990. See Constitution Watch: Latvia, E. EuR. CONST. Rev., Spring 1993, at 8-9. The 1938 Constitution was the basis for Estonia's constitutional draft. See Constirution Watch: Estonia, E. EuR. CONST. REV., Spring 1992, at 5. The basis for constitutional drafts in Georgia was the Constitution of 1921. See Draft of Georgian Constitution (on file with Center for the Study of Constitutionalism in Eastern Europe, Univ. of Chicago).

250. See Saj6, supra note 245 , at $854-55$ (arguing that restoration of such constitutions established in East-Central Europe in 1989 were expressions of reactionary nationalism). 
Retelling the American constitutionmaking from a transitional perspective adds a different narrative to the prevailing account. In the idealized version, the American revolution culminates with constitutionmaking. The Constitution embodies a putative immediacy bound up in the revolution, as well as a permanence. ${ }^{251}$ Yet the relationship between the United States Constitution and the American Revolution reflects a transitional constitutionalism both in its process and in its normative mandate. There was a stepwise progression from a backward-looking constitutionalism toward a more forward-oriented one. The Revolution did not immediately culminate with a foundational constitution, but rather produced a number of constitutive documents. ${ }^{252}$ In the first postrevolutionary five-year period, the Articles of Confederation constituted a transformative, critical response to a regime distinguished by minimal state power. A more expansive scheme of state power was created only upon the adoption of the Constitution of 1787. The addition of the Bill of Rights ${ }^{253}$ and the post-Civil War amendments to the American Constitution represented yet additional constitutive stages. ${ }^{344}$

Told this way, the story of the United States's constitutionmaking shares some affinities with transitional constitutionalism. This transition was not as dramatic, however, given the passage of time between the American Revolution and the enactment of the Constitution, and the nature of the American transition from limited monarchy rather than from the worst of dictatorships. Such a transition seems markedly conservative compared to others discussed here; ${ }^{255}$ the American constitutional instrument itself reflects this.

From a transitional perspective, the American Constitution is not a monolithic Founding instrument, but a nuanced document. The depiction of American constitutionmaking as a self-conscious founding glosses over the pronounced conflict among the Framers as to their purposes. ${ }^{256}$ Transitional

251. My description is no doubt an oversimplification of the Amencan constututional model. For a thoughtful account, see PAUL W. KAHN, LEGITMACY AND HISTORY 58-59 (1992), which argues that the process of constitutionalism shifted from revolution to mannenance.

252. A sequence of constitutional changes put in motion by the revolution led to the zadoption of the Constitution of 1787. The chain of constitutive documents begins with the Declaration of Independence's statement of justification to break with the prior regime. Even when the Framers convened in 1787. औ was with the purpose to amend the previous constitutive chanter. See RICHARD B. BERNSTEtr, ARE WE TO BE A NATION? THE MAKING OF THE CONSTIUTIION 106 (1987). For an argument that conunuity between the American Revolution and the United States Constitution was part of a single political expenence, see David A.J. Richards, Revolution and Constitutionalism in America. 14 CARDOZO L. REV 577, 577-78 (1993)

253. Though some scholars suggest the 1787 Consutution incorporates the Declaration. comparable claims have not been made about the Articles of Confederation Nevertheless, the Constitution impliciuly assumes some continuity with the Aricles; for example. the Union assumed all debis of the Confederation. See U.S. Const. an. VI, § 1 .

254. See infra notes $270-74$ and accompanying text. For the clatm that there are three such constututuve stages, see ACKERMAN, supra note 194, at 40, 58 .

255. For discussion of the continuum in transitions in terms of vanance in extent of liberalizing change, see supra note 13.

256. Compare Letter from James Madison to Thomas Jefferson (Feb. 4. 1790), in Marvis MEYers. THE Mnd OF THE FOUNDER: SOURCES OF THE POLTICAL THOUGHT OF JAMES MADISON 175-79 (rev cd. 
analysis exposes the unseen Constitution, those parts steeped in the historical and political contingencies of the day. That these provisions have been generally overlooked by contemporary scholars may well attest to this transient nature. A leading feature of the American Constitution's transitionality is its provision for amendment. ${ }^{257}$ Because the amendment process is difficult to incorporate within the dominant account, it has occasioned lively scholarly debate. ${ }^{258}$ The paradigm proposed by this Article suggests that the amendment process should not be considered in isolation, but in light of other aspects of constitutional change. In the American constitutionmaking sequence, the antecedent structural Constitution is the predicate to ultimate recognition of individual rights.

Transitionality also marks the constitutional provisions regarding rights, the leading transitional feature of which was the controversial issue of slavery. The 1787 Constitution postponed any change regarding federal legislative regulation of the slave trade until $1808 .{ }^{259}$ Thus the Constitution's resolution is twofold: There is one Constitution for the moment, where political debate is constrained and a federal solution imposed. The provisional language of the document, however, leaves open the possibility of another prospective resolution. ${ }^{260}$ When it came to perhaps the most politically contentious issue, the Constitution offered only an interim guiding principle. A transitional perspective also illuminates the distinctive understanding of constitutional justice. The Constitution's protections of freedom and its related conception of tyranny are better understood in the context of colonial rule. ${ }^{261}$ The primary such constitutional response, often considered the Constitution's crowning achievement, is the reconstruction of state power. ${ }^{262}$ The Constitution's

1981) (expressing skepticism over desirability of frequent constitutional upheaval and revision), with Letter from Thomas Jefferson to James Madison (Jan. 30, 1787), in THE PORTABLE THOMAS JEFFERSON 415,417 (Merrill D. Petersen ed., 1975) (arguing that "a little rebellion now and then is a good thing").

257. See U.S. CONST. art. V ("The Congress, whenever two thirds of both Houses shall deem it necessary, shall propose Amendments to this Constitution, or, on the Application of the Legislatures of two thirds of the several States, shall call a Convention for proposing Amendments . . . ."). On the amendment process, see RESPONDING TO IMPERFECTION (Sanford Levinson ed., 1995).

258. Much contemporary constitutional theory has focused on the question of how to reconcile the contemporary idealized foundationalist view of the enduring Constitution with constitutional change, whether predicated on the Article $\mathrm{V}$ amendment process, or through principles of constitutional interpretation departing from the original understanding, or by other means. See Akhil Reed Amar, Philadelphia Revisited: Amending the Constitution Outside Article V, 55 U. CHI. L. REv. 1043 (1988) (evaluating whether Article V ought to be regarded as sole source of constitutional change).

259. See U.S. CONST. art. I, $\$ 9, \mathrm{cl} .1$ ("The Migration or Importation of such Persons as any of the States now existing shall think proper to admit, shall not be prohibited by the Congress prior to the Year one thousand eight hundred and eight . . . ."). The Constitution also provides for the capture and extradition of fugitive slaves. See id. art. IV, § $2, \mathrm{cl} .3$.

260. This reading seems to be supported by the express limitation in Article $\mathrm{V}$ on such amendments until 1808. See id. art. V.

261. See Gordon S. WoOd, THE CREation of the American Republic 1776-1787 (1969) (discussing impact of years of colonial rule in shaping Union).

262. The Federalist defense of the new scheme of state power is orchestrated in terms of an argument from history, based on the experience of tyranny characterized by British Parliamentary sovereignty. See THE FEDERALIST No. 47, at 301 (James Madison) (Clinton Rossiter ed., 1961) ("The accumulation of all 
critical response to monarchic rule is its definition of executive power; $;^{263}$ an even more pronounced response to strong executive power is evident in the interim constitutional measures adopted after the revolution. ${ }^{204}$ The same was largely true of the state constitutions, where the governors' terms were limited and their powers few. ${ }^{265}$ Justifications for the structure of executive power relied on the historical experience of prior monarchic rule. ${ }^{266}$

The Constitution's provisions concerning republican rule also suggest a transformative function. First, reconstitution of the political order occurs through redefinition of political participation, membership, and leadership. ${ }^{267}$ The allocation of military and civilian power responds to abuses of military rule. ${ }^{268} \mathrm{~A}$ transitional perspective illuminates the contemporary understanding

powers, legislative, executive, and judiciary, in the same hands, whether of one. a few, or many, and whether hereditary, self-appointed, or elective, may justly be pronounced the very definition of tyranny.").

263. Note that the United States is virtually unique in turning to a presidentual system. Most former monarchies move from strong executive systems to parliamentary systems. See Karl Loewenstean. The Presidency Outside the United States: A Srudy in Comparame Polincal Insnnunons, 11 J POL. 447. 462 (1949). The American anomaly is best explained within a transituonal analysis.

264. At the time of the Articles of Confederatuon. distrust of centralized power was so powerful that the Continental Congress was impotent to tax and regulate commerce. Antele Vlll provided that:

[E]xpenses that shall be incurred for the common defence or general welfare, and allowed by the United States in Congress assembled, shall be defrayed out of a common treasury, which shall be supplied by the several States, in proportion to the value of all land within each state. ... The taxes for paying that proportion shall be laid and levied by the authonty and direction of the Legislatures of the several States ...

ARTICLES OF CONFEDERATION, 1781, art. VIII. Article LX, in turn, provided

The United States in Congress assembled, shall have the sole and exclustve nght and power of . . . entering into treaties and alliances, providod that no treaty of commerce shall be made whereby the legislative power of the respective States shall be restranned from prohibitung the exportation or importation of any species of goods or commodiues whatsoever Id. art. IX.

For an argument suggesting a reading of the American Constutution in light of its hustoncal legacy in the Articles of Confederation, though one not explicitly characterized as transultonal, see Akhul Reed Amar, The Bill of Rights as a Constitution. 100 YALE L.J. 1131. 1150-51 (1991)

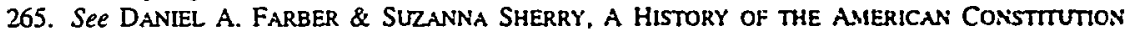
$80-81(1990)$.

266. The reasoning in the Federalist arguments for the proposed exceutuve power works backward from the institution of the King. Whereas the King's rule was unbounded, the four-year himited presidental term prevents abuse of power. See THE FEDERALIST No. 69. at 415-16 (Alexander Hamiton) (Clinton Rossiter ed., 1961). Other features of the proposed presidentual powers have analogous justufications. Because the King's veto power was plenary, it followed that the qualified presidenual veto is limuled and appropnate See id. at 416-17. The extent of historical monarchic powers is used to jusaly the proposed qualified presidential treaty power, as well as the Presideni's constraned war power See id. at 417-20

267. Anti-aristocratic features appear in a number of consututional provisions, most prominenily in the express prohibition of nobility. See U.S. CONST. an 1. \$9. cl 8 ("No Title of Nobility shall be granted by the United States: And no Person holding any Office or Profit or Trust under them, shall. without the Consent of the Congress, accept of any present, Emolument. Office, or Tile, of any kand whalever, from any King, Prince, or foreign State."); id. art. I. \& 10, cl. I ("No State shall . grant any Title of Nobility."); THE FEDERALIST No. 84, at 511-14 (Alexander Hamilton) (Clinton Rossiter ed., 196!) Qualifications and terms for political participation and representation indicate a critucal response to the prior order. See U.S. CONST. art. I, § 2; id. an. Il, § 1; id. an. IIl. § li see also THE FEDERALIST Nos 52.53. at 327-30, 330-32 (James Madison) (Clinton Rossiter ed., 1961)

268. See U.S. CONST. ar. I, § 8, cls. 11-16 (granting Congress significant miltary powers). td. amend II ("A well regulated Militia, being necessary to the secunty of a free State. the nght of the people to keep and bear Arms, shall not be infringed."); id. amend. III ("No Soldier shall. in tumes of peace be quartered in any house, without the consent of the Owner, nor in tume of war. but in a manner to be prescribed by 
of rights provisions such as the Second Amendment. ${ }^{269}$

A vivid illustration of transitional constitutionalism is Reconstruction, a time of profound struggle over how to transform the Union. The Reconstruction Amendments appear highly backward-looking, as they normatively structure the constitutional status of the confederate secession. ${ }^{270}$ The Amendments respond to the evil of slavery by imposing new obligations on the Southern States; only by affirming the principle of equality under law, could states reenter the Union and be equally represented in Congress. ${ }^{271}$ Conditions for public office in the Fourteenth Amendment disqualified Confederate supporters. ${ }^{272}$ Reconstruction's political disabilities would ultimately be short-lived. ${ }^{273}$ Nevertheless, they remain forever in the text of the American Constitution as an enduring expression of extraconstitutional politics. Understanding the transitional relationship between post-Civil War constitutional law and politics has profound implications for contemporary debates concerning the interpretation of the Reconstruction Amendments. ${ }^{274}$ A transitional perspective evaluates the Reconstruction jurisprudence within its context of political transformation, with implications for contemporary controversies.

This Section has suggested ways in which the American Constitution can be better understood from a transitional perspective. By offering a more nuanced view of the nature and role of constitutionalism, the above discussion complements the prevailing model. Transitional constitutionalism also has implications for constitutional interpretation. A transitional perspective contributes a unique view to debates over the ongoing relevance of "original

law.").

269. See id. amend. II; Sanford Levinson, Comment: The Embarrassing Second Amendment, 99 Y ALE L.J. 637, 648 (1989) (noting that one foundation of Second Amendment was "well-justified concern about political corruption and consequent government tyranny").

270. See U.S. CONST. amend. XIV, $\S 4$ ("But neither the United States nor any State shall assume or pay any debt or obligation incurred in aid of insurrection or rebellion against the United States . . but all such debts, obligations and claims shall be held illegal and void.").

271. See id. amend. XIV, $\$ 11-2$.

272. The Fourteenth Amendment states:

No person shall be a Senator or Representative in Congress, or elector of President and Vice

President, or hold any office, civil or military, under the United States, or under any State, who, having previously taken an oath, as a member of Congress, or as an officer of the United States, or as a member of any State legislature, or as an executive or judicial officer of any State, to support the Constitution of the United States, shall have engaged in insurrection or rebellion against the same, or given aid or comfort to the enemies thereof. But Congress may by a vote of two-thirds of each House, remove such disability.

Id. amend. XIV, \& 3. This Section took effect in July 1868.

273. As provided for in the Amendment itself, most of the disqualifications were removed by Congress by 1872. See KENNETH M. STAMPP, THE ERA OF RECONSTRUCTION 193 (1970).

274. Compare RAOUl Berger, GovernMENT BY JUDICIARY 157-245, 167 (1977) (arguing that "framers meant to outlaw discrimination only with respect to enumerated privileges" and that Framers did not intend "to open goals beyond those specified in the Civil Rights Act and constitutionalized in the Amendment"), with Robert J. Kaczorowski, Revolutionary Constitutionalism in the Era of the Civil War and Reconstruction, 61 N.Y.U. L. REV. 863, 881-903, 910-35 (1986) (explaining amendments in context of republican theory of federal citizenship and generic nature of fundamental rights). 
intent" to the contemporary significance of relevant constitutional provisions. ${ }^{275}$ The transitional perspective shares with the "fidelity" school of interpretation ${ }^{276}$ the understanding that constitutions are best examined in light of historical and political contexts, but it adds to the understanding of constitutions as codifying purposes that are transformative and dynamic. The relevant interpretive inquiry might be to what extent the relevant constitutional provision is considered transitional and whether transformative in purpose. With the passage of time, transitional constitutional features will operate in a dynamic fashion, either withering away or expanding in their transformative purposes. This mix of possible original purposes advises a more nuanced approach to the relevance of original intent. Thus the transitional perspective offers a distinctive principle of constitutional interpretation with a number of interpretive consequences.

\section{Transitional Constitutionalism: Some Conclusions}

Prevailing constitutional theorizing does not fully account for the constitutional phenomena associated with substantial political change. This is particularly true of the late twentieth century. The central ideas of modern constitutionalism are its eighteenth-century response to premodern rule and its restraint on political arrangements. Constitutionalism in its third century, however, is both normative and transformative in its response to the preexisting political order. Such constitutionalism displays a dialectical quality of varying modalities: critical, residual, and restorative. ${ }^{27}$ As such, this paradigm helps account for the threshold dilemma created by constitutionmaking in revolutionary times. Transitional constitutionalism bridges radical political change by reconciling dichotomous understandings of law and politics. Moreover, transitions demonstrate how constitutionalism

275. See BERGER, supro note 274 (defending originalism): ROBERT H. BORK. THE TEMPTLY OF AMERICA: THE POLITICAL SEDUCTION OF THE LAW (1990) (same); Roben H Bork. The Consuturton. Original Intent, and Economic Rights, 23 SAN DIEGO L. REV. 823 (1986) (same): see also Paul Brest. The Misconceived Quest for the Original Understanding. 60 B.U. L. REV 204 (1980) (crituciang onginalism). Henry Monaghan, Our Perfect Constiturion, 56 N.Y.U. L. REV 353, 374-87 (1981) (cntucizing Brest, supra); H. Jefferson Powell, Rules for Originalists. 73 VA. L. REV. 659 (1987) (offenng it pnneiples for originalist interpretation); Mark V. Tushnet. Following the Rules Latd Down: A Crinque of Interpremism and Neurral Principles, 96 HARV. L. REV. 781.786-804 (1983) (denying possibility of onginalism without communitarian underpinnings).

For a thoughtful perspective on originalism that argues for ts relevance as a lloor, see generally Jed Rubenfeld, Reading the Constiturion as Spoken, 104 Y ALEE L.J 1119 (1995). which uncorporales ongunalism into "commitmentarian" interpretive model.

276. On "fidelity" to the Constitution, see generally Lawrence Lessig. Fudelin in Translanon, 71 TEX L. REV. 1165 (1993). The central idea of this interpretuve theory is the preservation of meanung reross ume and context. But see Lawrence Lessig. What Drives Dern abilin. Responses to Responding to Imperfection. 74 TEX. L. REV. 839 (1996). From a transitional perspectuve. however. the problem in this approach is that it generally assumes a unitary, constitutional purpose over tume, missing other more iransformatuve purposes of a dynamic nature.

277. See supra notes $197-98$ and accompanying text 
reinforces democracy. In ordinary times, constitutionalism appears in conflict with democracy, but during times of transition, constitutionalism plays a unique role in facilitating the move to a more liberal regime.

Transitional constitutionalism provides an alternative paradigm. The paradigm's distinctive paradox is that, as in the premodern conception, constitutionalism does not stand independently from the political order but is inextricably enmeshed in transformative politics. Nevertheless, as in the modern conception, transitional constitutions also transcend transitory political arrangements. The transitional paradigm elaborates a more nuanced relationship between constitutional and ordinary politics: Transitional constitutions not only operate as codifications of prevailing consensus but also transform that consensus. Moreover, these two concepts of constitutional purpose are not mutually exclusive; indeed, they may well coexist within a single instrument. ${ }^{278}$ Thus the view proposed here complements prevailing constitutional theory. What distinguishes the transitional constitutional paradigm is its constructive relation to a political order in flux. Transitional constitutionalism comprehends different phases; ranging from provisional measures intended to shape the transient political order for a limited time to those entrenched and even superentrenched laws that guide a state's core political identity. In its disentrenching role, the transitional constitution ratifies new political arrangements to liberalize political space, enabling a more liberal order. Transitional constitutionalism varies from provisional to ultraentrenched, as guardian of the future constitutional order.

The paradigm of transitional constitutionalism illuminates the special contribution of constitutionmaking in periods of political change. In eschewing the prevailing tendency to collapse constitutionalism with revolutionary political change, the proposed paradigm has the virtue of creating a space for the critique of the nature and role of constitutionalism in periods of transformation. The paradigm of transitional constitutionalism also has implications for our understanding of constitutionalism's normative force and its relation to other uses of the law. Critical constitutionalism implies an explicitly transformative response to prior repressive rule. To the extent that the constitutions discussed above reflect a critical response to the legacy of the ancien régime, transitional constitutionalism enables a sense of justice. Critical constitutional responses to the predecessor political regime also play a justificatory role for the transition by delegitimating aspects of the ancien régime and legitimating its successor. To the extent that these structural principles enable normative expressions of accountability, they overlap with other normative uses of the law, such as criminal law, in these extraordinary

278. They often do. See supra notes 187-94 and accompanying text (regarding American Constitution). 
periods. ${ }^{279}$ Contemporary postmodern constitutional norms delimit and transcend the structuring of state power to guide broader normative understandings of the social order. Finally, a transitional constitutional perspective offers a glimpse of constitutional progress. This vision of progress is not essential or universal but limited and contingent. Understandings of distinctive national legacies of injustice enable construction of constitutional constraints truly responsive to a state's political, historical, and constitutional legacies.

\section{A TRANSITIONAL JURISPRUDENCE}

Let us return to the questions posed at the outset: What is the relationship between legal responses to past repression and a state's prospects for meaningful liberalizing political change? How do societies make the transition from illiberal regimes? What are the nature and role of law in this transformation? The legal responses analyzed here occur within a bounded period following the change in regime, heralding a shift to a more liberal regime. Such periods are not easily captured within prevailing theorizing about the rule of law in a liberal state. Transitional jurisprudence examines the way law mediates such periods and constructs the transition, thereby describing this bounded domain. Affinities in the forms of responsive law-adjudicatory, punitive, and constitutional - point to a paradigm of transformative law. Legal practices in such periods reveal a struggle between two points, between settled and revolutionary times, as well as a dialectically induced third position. Persistent dichotomous choices arise as to law's role in periods of political change: backward versus forward, retroactive versus prospective, continuity versus discontinuity, individual versus collective, law versus politics. Transitional legal mechanisms mediate these antinomies.

In periods of political change, the role of law defies the categories and guiding principles governing ordinary periods. In ordinary times, law is largely continuous and prospective. In transitional times, by contrast, law's directionality is ambivalent; it is simultaneously continuous and discontinuous, retrospective and prospective. Thus in the "transitional domain," the rule of law does not follow idealist conceptions: Instead, the rule of law is constructed in relation to past conceptions of injustice, and an extraordinary form of the rule of law emerges. ${ }^{280}$ The role and function of the transitional criminal law are similarly distinctive from punishment in ordinary times. In the transitional criminal sanction, an extraordinary form of limited sanction emerges. Sanctions ordinarily establish individual responsibility for past wrongdoing, but in transitional times, the foci are the relations of the past to the present and the

279. See supra text accompanying note 96.

280. See supra Section I.E. 
individual to the collective. ${ }^{281}$ Transitional constitutional law also takes on a distinctive form. In ordinary times, constitutionalism is conceived as entirely forward-looking in nature, designed to endure for generations. Constitutionalism in transitional times is particularly retrospective in nature, justificatory and constructive of the political transformation. ${ }^{282}$

Transitional law is fluid in form. This fluidity bears on the central normative question in this area of study: Which ideal legal response is most likely to usher in a lasting democratic system? ${ }^{283}$ Yet with the breakdown in categorical uses of the law, the question becomes irrelevant, a remnant of ordinary times. Transitional constitutions serve apparently ordinary, regulative purposes. Criminal and civil sanctions are used interchangeably to generate rights and duties. Transitional adjudication seems unfair, trials lack punishment, and constitutions do not last. Affinities in the various forms of transitional law-procedural, penal, constitutional-underscore law's ultimate transformative role in the construction of transition. The law expresses new norms and does the work of reconstruction.

What is the role of law in periods of transformation? For some time, critical theorists have been engaged in comparative work regarding transitions, yet the object of inquiry has generally been the transmittal of societal norms or societal reproduction across generations and over time. ${ }^{284}$ But the ordinary social construction and legitimation problems are inapposite in extraordinary periods of political upheaval. The question of social transformation replaces the question of social reproduction. Although such periods are commonly envisioned as moments of rupture, I suggest that there is rarely such total discontinuity but instead various processes and mechanisms that enable mediation of the past towards transformation. It is through familiar forms that societies comprehend liberalizing change. The question then becomes how to synthesize transformation within the law.

How do legal responses help to enable the transition? In the transitional model, transformation occurs through the use of law to clarify and sanction past wrongs. Through investigatory and condemnatory processes, the law exposes and delegitimates the value system associated with past rule, clearing the way for transformative norm change. Legal measures promote creation of public knowledge about past wrongdoing, and judicial opinions, trials, and constitutions provide formal, public justifications. The law, therefore, contributes to the epistemological and interpretive changes necessary to comprehend transition; through public justification legal forms reconstitute

281. See supra Section II.D.

282. See supra Section III.C.

283. See supra text accompanying notes $1-2$.

284. For example, Berger and Luckmann describe the ordinary legitimation problem as arising in the institutional reproduction between generations. See BERGER \& LUCKMANN, supra note 17, at 86; see also CONNERTON, supra note 171 . 
state and societal interests, thereby instantiating transition. The uses of the law here are particularly well-suited to the legitimation problems inherent in periods of massive political change. All of these practices, in one fashion or another, are attempts to delimit and pass judgment upon past abuses of state power. Affinities in these responses suggest that these practices do not arbitrarily depart from the rule of law but recognize past abuses of power by the state. The legal responses to systematic persecution attempt to supervene and transcend prevailing politics.

The analysis of transitional jurisprudence offers some sense of how societies work through repressive periods to periods of greater liberality. Indeed, we might conceive of the transitional legal mechanisms as mediating between repressive and liberal regimes. Ultimately it is in part through these legal phenomena that we grasp whether a transition has occurred. These legal responses help to construct the transition. These mediating mechanisms and structures publicly elucidate and justify the normative changes associated with political transformation. These mechanisms, whether adjudicatory procedures, trials, or constitutionmaking, are ultimately the symbols of working liberal regimes; thus, as the transitional justice problem is resolved, the society has already begun to operate as a more liberal order. Although transitional jurisprudence comprehends justice claims associated with liberalizing change, these claims are not equivalent to those of a fully established democracy. Accordingly, recognition of a transitional jurisprudence provides a vocabulary for critical appraisal of legal developments in the context of liberalizing political change.

Further, the field of transitional jurisprudence has implications for better understanding of law's role in social change. The operation of the law in these periods follows neither the traditional liberal view of law as largely autonomous from politics, nor the critical view of law as epiphenomenal. Recognition of this domain raises a challenge to critical legal theorizing. As distinguishable from the role of law in ordinary times, the uses of the law discussed above construct the very understandings of radical political change. Recognition of this hyperpoliticized transformative domain is inconvenient for liberal theories of law as well as for political theorizing that attempts to make normative forecasts about law's bearing upon societal prospects for liberal consolidation.

\section{CONCLUSION}

This Article gives an account of the nature and role of law in periods of political transformation. It suggests that legal forms during such periods point to a transitional jurisprudence constituted by and constitutive of the transition. The transitional jurisprudence associated with periods of political upheaval ultimately also plays a role in shaping the sense of liberalizing change. 
Recognizing a distinct domain of transitional jurisprudence should have profound consequences for prevailing legal theorizing, and, in particular, for our normative understanding of law's relation to politics. Beyond its contribution to understanding law's role in periods of political change, transitional jurisprudence advances the critique of prevailing theories of justice. An understanding of the conception of law proposed here can help mediate the liberal-critical debate over theories of law. The liberal idealization views law as independent from culture and politics, and conceptualizes justice from an idealist "original" position. ${ }^{285}$ The view of justice offered here, by contrast, is concededly from a transitional position. ${ }^{286}$ The legal practices discussed above suggest that the content of justice and rights are understandings determined not in the abstract, but rather in response and in relation to legacies of injustice within a distinctive transitional context. ${ }^{287}$

285. See generally RAWLs, supra note 6 , at 22-28.

286. I only offer this point here, leaving for my forthcoming book broader treatment of this question. See TEITEL, supra note $\dagger$.

287. The conception of justice put forward here shares affinities with certain political theorizing. See EDMOND N. CAHN, THE SENSE OF INJUSTICE: AN ANTHROPOCENTRIC VIEW OF LAW (1949) (arguing for situated rather than abstract legal philosophy); Judith Shkiar, The Liberalism of Fear, in LIBERALISM AND THE MORAL LIFE 21 (Nancy L. Rosenblum ed., 1989) (discussing relationship between concrete political crisis and theories of justice). 